\title{
A Peptide Dendrimer Enzyme Model with a Single Catalytic Site at the Core
}

Sacha Javor, Estelle Delort, Tamis Darbre* and Jean-Louis Reymond*

Department of Chemistry and Biochemistry, University of Bern, Freiestrasse 3, 3012 Bern, Switzerland.

Fax: +41 3163180 57; Tel+41 3163143 25;

E-mail: jean-louis.reymond@ioc.unibe.ch

\section{Supporting Information}

\section{Table of contents}

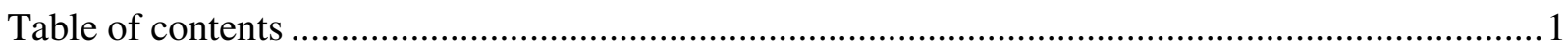

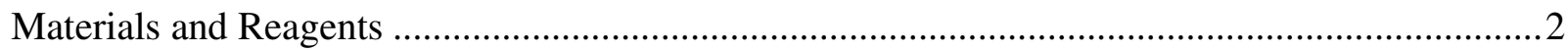

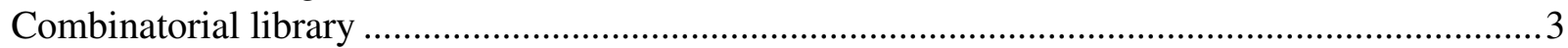

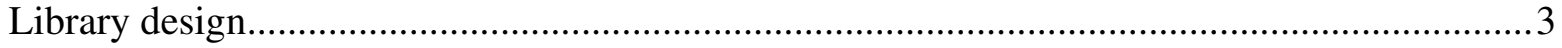

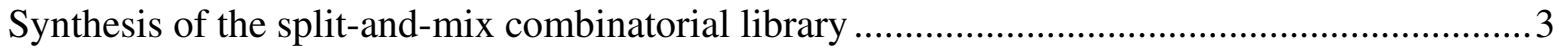

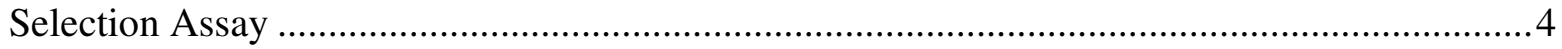

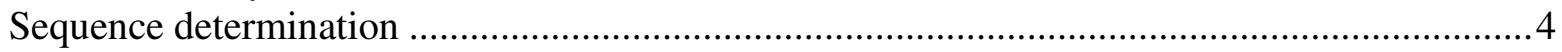

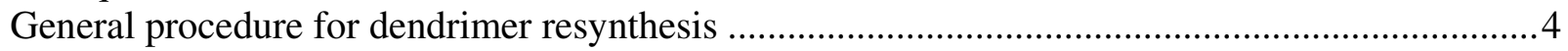

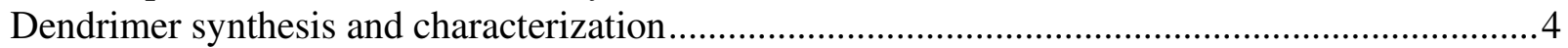

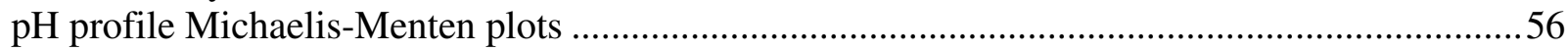

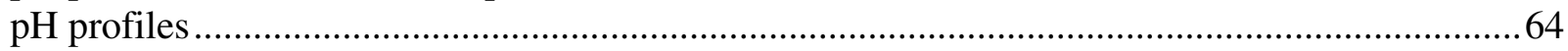

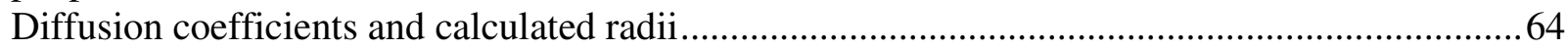




\section{Materials and Reagents}

Peptide syntheses were performed manually in a syringe reactor. All reagents were either purchased from Aldrich, Fluka (Switzerland) or Acros organics. BOP, amino acids and their derivatives were purchased from Senn Chemicals or Novabiochem (Switzerland).

Amino acids were used as the following derivatives: Fmoc-Ala-OH, Fmoc-Asp(Ot-Bu)-OH, Fmoc-Cys(Trt)-OH, Fmoc-His(Boc)-OH, Fmoc-Leu-OH, Fmoc-Phe-OH, Fmoc-Ser( $t$-Bu)-OH, Fmoc-Thr( $t$-Bu)-OH, Fmoc-Ile-OH, Fmoc-Arg(Pbf)-OH, Fmoc-Gly-OH, Fmoc-Trp(Boc)-OH, Fmoc-Tyr $(t-\mathrm{Bu})-\mathrm{OH}$, Fmoc-Pro-OH.

FmocDap(Fmoc)-OH was purchased from BACHEM. NovaSyn ${ }^{\circledR}$ TGR resin (loading: 0.23 or $0.26 \mathrm{mmol} / \mathrm{g}$ ), and Rink amide (loading: $0.63 \mathrm{mmol} / \mathrm{g}$ ), was purchased from Novabiochem (Switzerland).

Analytical RP-HPLC was performed in Waters (996 Photo diode array detector) chromatography system using an Atlantis ${ }^{\circledR}, \mathrm{dC} 18,5 \mu \mathrm{m}, 4.6$ x $100 \mathrm{~mm}$ column with a flow rate $3.0 \mathrm{~mL} \cdot \mathrm{min}^{-1}$. Compounds were detected by UV absorption at $214 \mathrm{~nm}$. Preparative RP-HPLC was performed with HPLC-grade acetonitrile and MilliQ deionized water in a Waters prepak cartridge $500 \mathrm{~g}$ (RP-C18 20 mm, 300 Á pore size) installed on a Waters Prep LC4000 system from Millipore (flow rate $100 \mathrm{~mL} \cdot \mathrm{min}^{-1}$, gradient $0.60 \% \mathrm{~min}^{-1} \mathrm{CH}_{3} \mathrm{CN}$ ).

MS spectra were provided by the Service of Mass Spectrometry of the Department of Chemistry and Biochemistry, University of Bern.

Kinetic measurements were carried out using a CytoFluor® Series 4000 multi-well plate reader from PerSeptive Biosystems.

The diffusion NMR measurements were performed by the NMR service of the Department of Chemistry and Biochemistry of the University of Bern using a Bruker DRX400 or DRX500 spectrometer. 


\section{Combinatorial library}

Library design

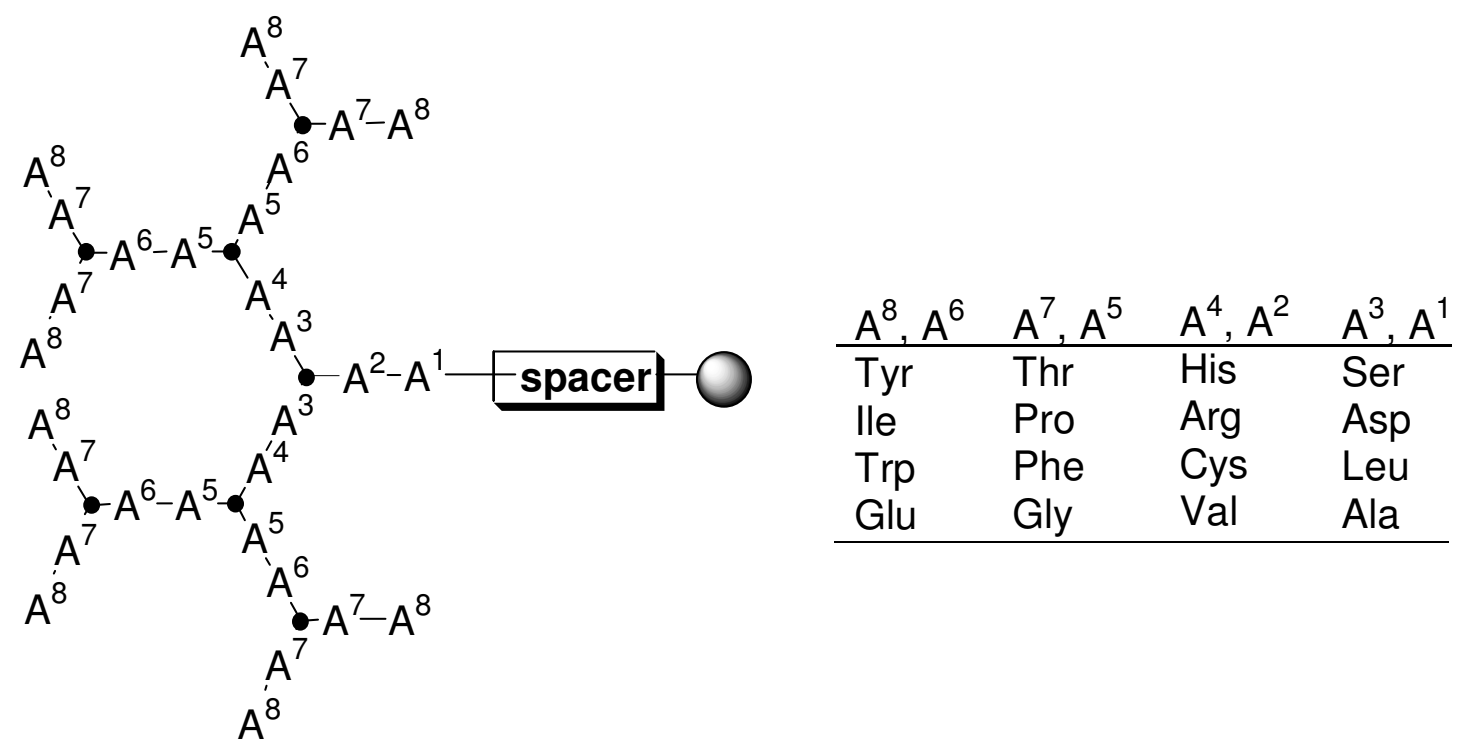

\section{Synthesis of the split-and-mix combinatorial library}

The peptide-dendrimer library was prepared from a $400 \mathrm{mg}$ resin batch of NovaSyn ${ }^{\circledR}$ TG $(0.30$ $\mathrm{mmol} / \mathrm{g}$ ) divided equally in 4 reactors. The sequence started with an amino-hexanoyl-glycine spacer introduced by successive couplings with Fmoc-Gly-OH and Fmoc-6-Ahx-OH (3 eq) in the presence of BOP (3 eq) and DIEA (5 eq) for $30 \mathrm{~min}$. Then in each of the four reactors, the resin was acylated with one of the four amino acids ( $3 \mathrm{eq})$ in the presence of BOP ( $3 \mathrm{eq})$ and DIEA (5 eq). Amino acids were acylated for 1h30, and Dap was coupled for $2 \mathrm{~h}$. After each coupling, the 4 resin batches were then mixed together through nitrogen bubbling for $15 \mathrm{~min}$, then splat into four parts, equally introduced in the four reactors. These split-and-mix steps were repeated after each amino acid coupling. After each coupling or deprotection the resin was successively washed with DMF, $\mathrm{MeOH}$, and $\mathrm{CH}_{2} \mathrm{Cl}_{2}$ (3× with each solvent). Couplings were checked using the TNBS test. Couplings after proline residues were checked using the chloranil test. If the test indicated the presence of free amino groups, the coupling was repeated. The Fmoc protecting groups were removed with a solution of $20 \%$ piperidine in DMF $(2 \times 10 \mathrm{~min})$ and the solvent was removed by filtration. At the end of the synthesis, the Fmoc protected resin was dried and stored at $4{ }^{\circ} \mathrm{C}$. Just before screening, the Fmoc protecting groups were removed and the last amino acid was acetylated with acetic anhydride/ $\mathrm{CH}_{2} \mathrm{Cl}_{2}(1: 1)$ for $1 \mathrm{~h}$. The side-chain protecting groups were 
removed with TFA/TIS/ $\mathrm{H}_{2} \mathrm{O}$ (94:5:1) for $2 \mathrm{~h} 30$, resulting in a functional dendrimer library on beads.

\section{Selection Assay}

Activity screening was performed by swelling the beads for $1 \mathrm{~h}$ in aqueous buffered solution (Bis Tris $\mathrm{pH}$ 6.0), then by soaking the beads in an aqueous buffered solution of a fluorogenic ester substrate for $8 \mathrm{~min}$ and spreading the slurry of beads onto a silicagel plate in a Petri dish. Whereas the solvent quickly evaporated at the TLC plate surface, evaporation inside the beads was slow, so that each bead functioned as a separate micro reactor. Under UV radiation $(365 \mathrm{~nm})$ the beads showed an intense green fluorescence indicating product formation. These active beads were picked, washed thoroughly with buffer and water, and subjected to amino acid analysis.

\section{Sequence determination}

Single dendrimer-containing resin beads were hydrolyzed with aqueous $\mathrm{HCl}(6 \mathrm{M})$ at $110^{\circ} \mathrm{C}$ for $22 \mathrm{~h}$. The amino acids were derivatized with phenylisothiocyanate (PITC) and the phenylthiocarbamyl (PTC) derivatives analyzed on a reverse phase C18 Novapack column.

\section{General procedure for dendrimer resynthesis}

Prior to every reaction the resin was swelled in $\mathrm{CH}_{2} \mathrm{Cl}_{2}$. The resins NovaSyn ${ }^{\circledR}$ TGR or Novagel, were acylated with each amino acid or diamino acid (3.0 eq) using procedure A: BOP (3.0 eq) and DIEA (5.0 eq) or procedure B: DIC (3.0 eq) and HOBt (3.0 eq), both procedures in a mixture of NMP/DCM (3:1) The Fmoc protecting groups were removed with a solution of $20 \%$ piperidine in DMF $(2 \times 20 \mathrm{~min})$. At the end of the synthesis, the resin was acylated with acetic anhydride/ $\mathrm{CH}_{2} \mathrm{Cl}_{2}$ (1:1) for $20 \mathrm{~min}$. The cleavage was carried out with TFA/TIS/ $\mathrm{H}_{2} \mathrm{O}$ (94:5:1) for 6 h. The peptide was precipitated with methyl tert-butyl ether then dissolved in a water/acetonitrile mixture. All dendrimers were purified by preparative HPLC and obtained as TFA salts after lyophilization.

\section{Dendrimer synthesis and characterization}

In the following dendrimer sequences, Dap refers as the (S)-2,3-diaminopropanoic acid and Ac as acetyl group. The NMR integration of the G3 dendrimers is usually not exploitable due to the poor baseline. The analysis is then based on the chemical shifts and signal shapes only. For the kinetics the concentrations are expressed in $\mu \mathrm{M}$ and the time unit is second. 


\section{Peptide R-G0: Ac-Arg-Ser-Ala-His-Ser-NH2}<smiles>CC(=O)N[C@@H](CCCNC(=N)N)C(=O)N[C@@H](CO)C(=O)N[C@@H](C)C(=O)N[C@@H](Cc1c[nH]cn1)C(=O)N[C@@H](CO)C(N)=O</smiles>

Starting with $250 \mathrm{mg}$ of Rink amide Novagel resin $(0.63 \mathrm{mmol} / \mathrm{g})$, the peptide R-G0 was obtained using procedure B as colorless solid after cleavage from the resin and preparative RPHPLC purification $(2.9 \mathrm{mg}, 2.2 \%)$.

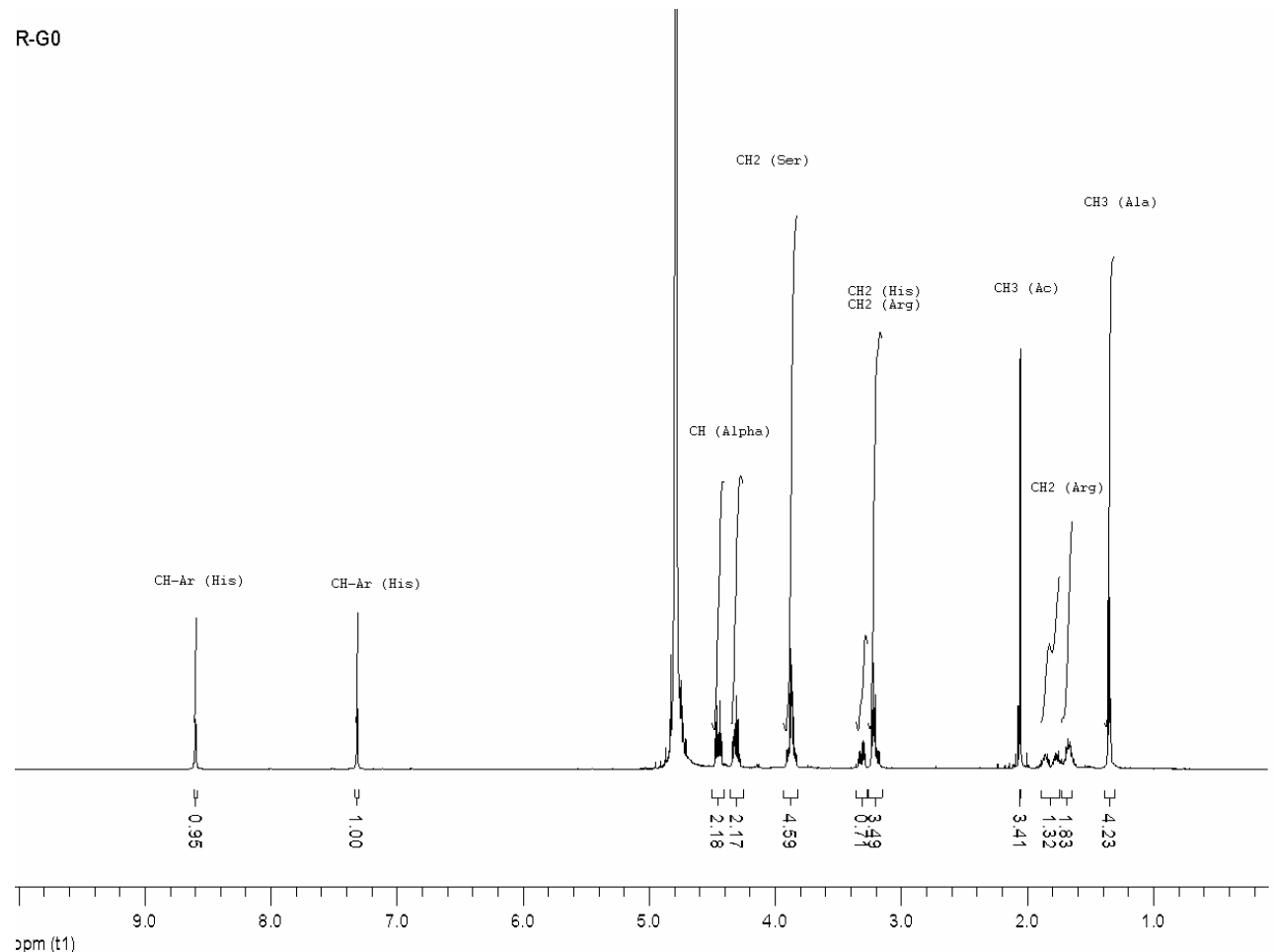


Preparative RP-HPLC: $t_{\mathrm{R}}=11 \min (\mathrm{A} / \mathrm{B}=100 / 0$ to $\mathrm{A} / \mathrm{B}=70 / 30$ in $30 \mathrm{~min})$

Analytical RP-HPLC: $t_{\mathrm{R}}=2.9 \min (\mathrm{A} / \mathrm{B}=100 / 0$ to $\mathrm{A} / \mathrm{B}=0 / 100$ in $10 \mathrm{~min})$

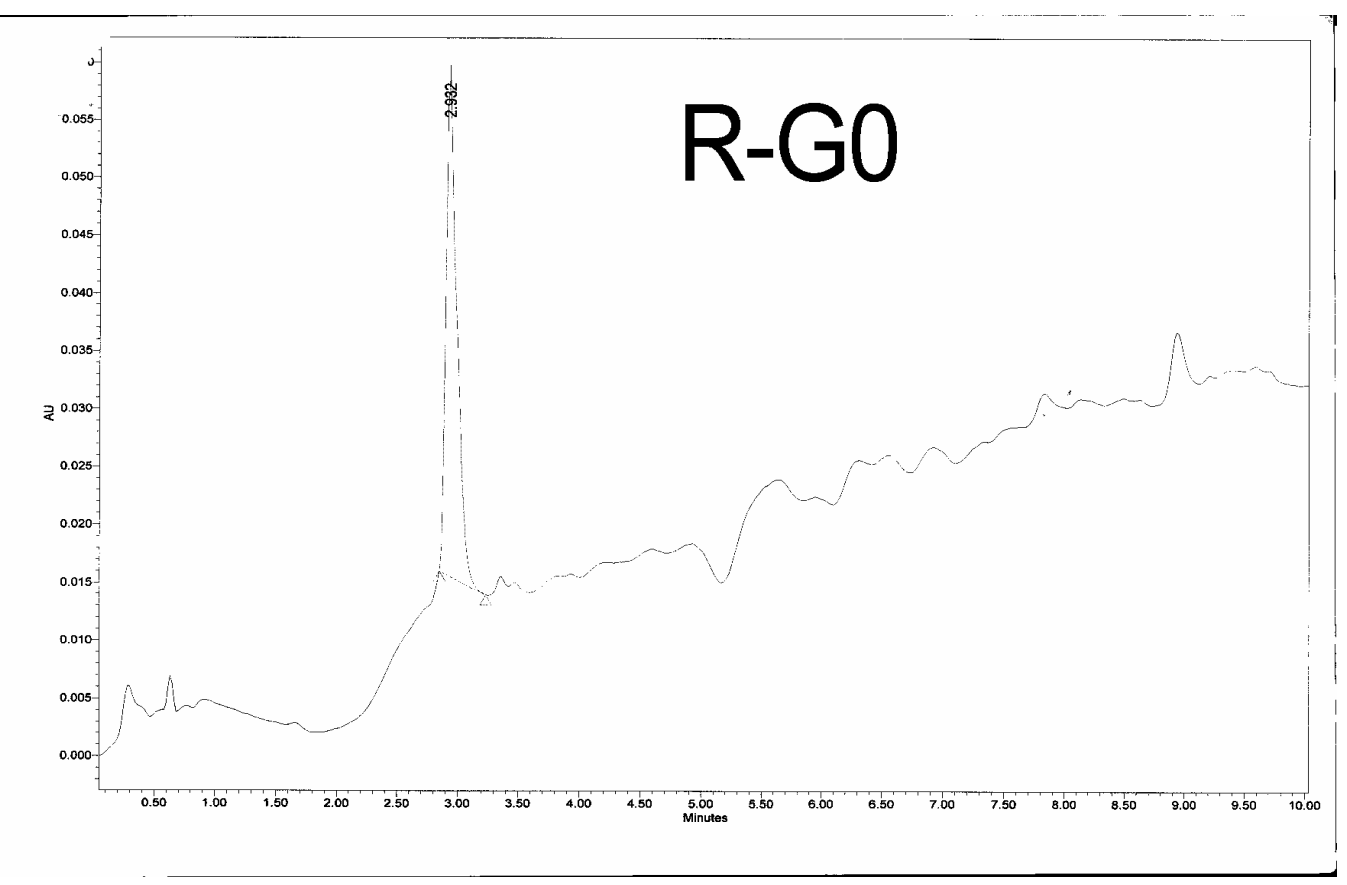

MS (ES+) calcd for $\mathrm{C}_{23} \mathrm{H}_{40} \mathrm{~N}_{11} \mathrm{O}_{8}[\mathrm{M}+\mathrm{H}]^{+}:$598.3, found: 598.6; $[\mathrm{M}+2 \mathrm{H}]^{2+} / 2: 299.7$, found: 300.0 .

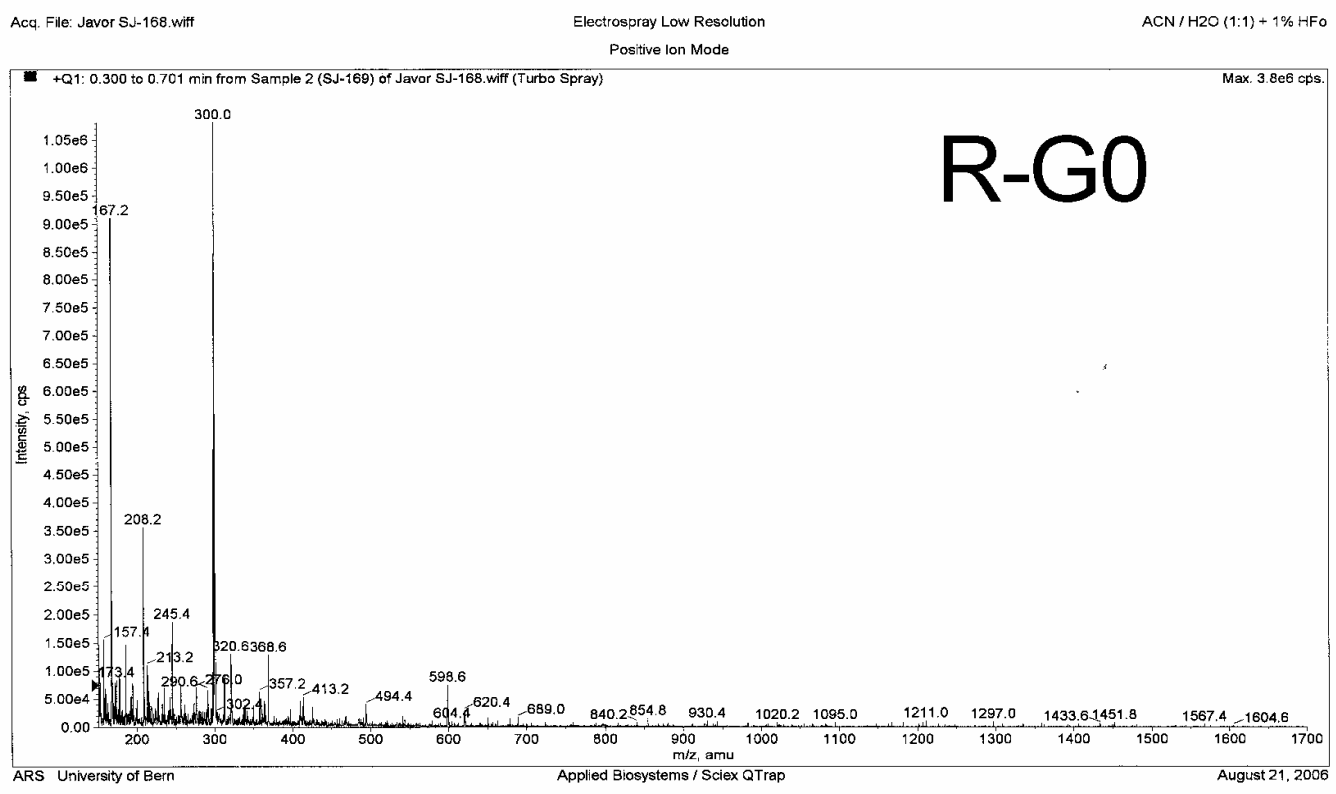

Department of Chemistry and Biochemistry 
Michaelis-Menten plots for determination of $\boldsymbol{k}_{c a t}$ and $\boldsymbol{K}_{M}$
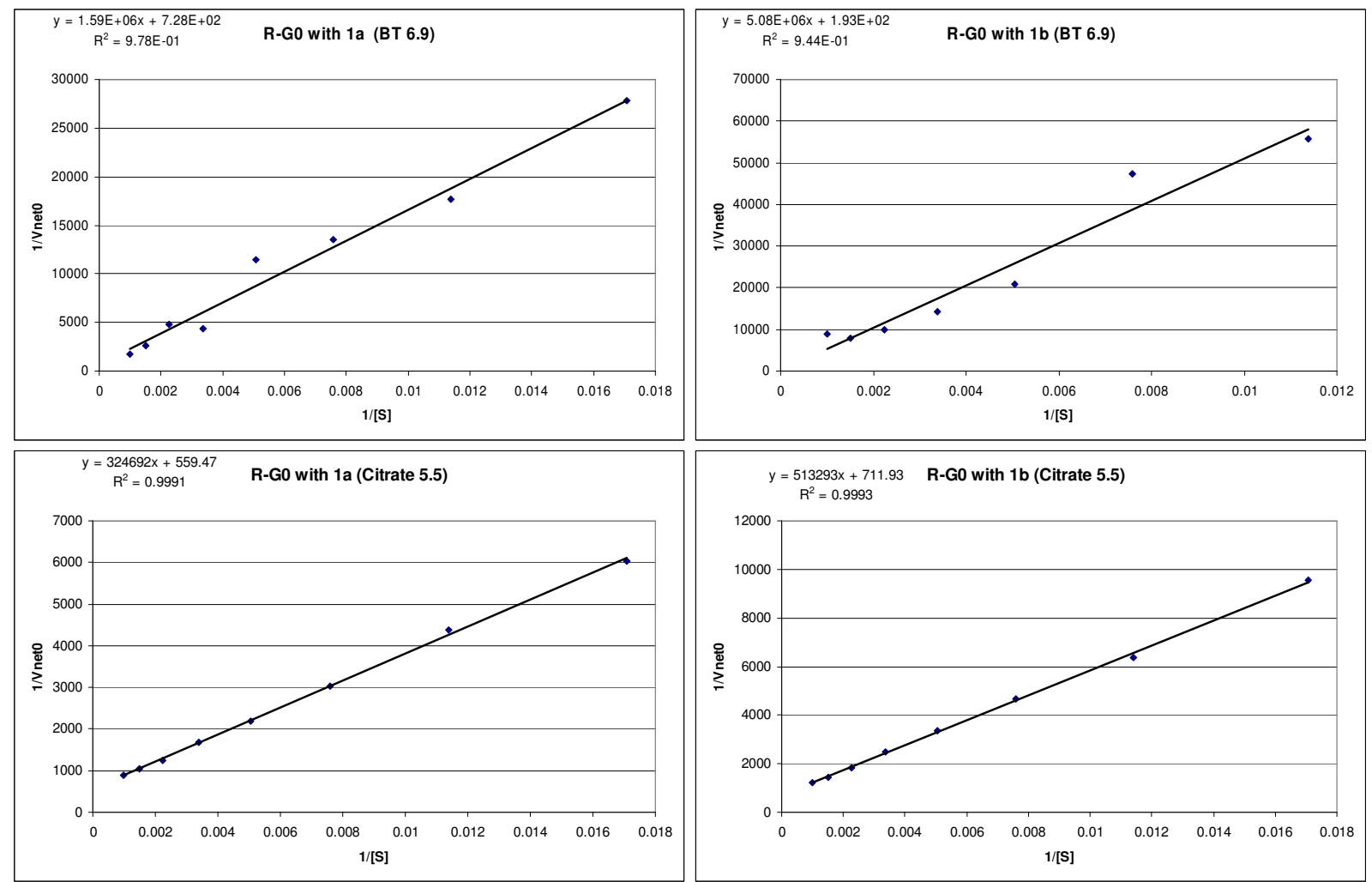


\section{Dendrimer R-G1: (Ac-Arg-Ser) ${ }_{2}$ Dap-His-Ser-NH 2}<smiles>CC(=O)NC(CCCCNC(=N)N)C(=O)N[C@@H](CO)C(=O)NC[C@H](NC(=O)[C@H](CO)NC(=O)CCCNC(=N)N)C(=O)N[C@@H](Cc1c[nH]cn1)C(=O)N[C@@H](CO)C(N)=O</smiles>

Starting with $100 \mathrm{mg}$ of NovaSyn ${ }^{\circledR}$ TGR resin $(0.25 \mathrm{mmol} / \mathrm{g})$, the dendrimer R-G1 was obtained using procedure A as colorless foamy solid after cleavage from the resin and preparative RPHPLC purification $(8.5 \mathrm{mg}, 27.5 \%)$.

R-G1

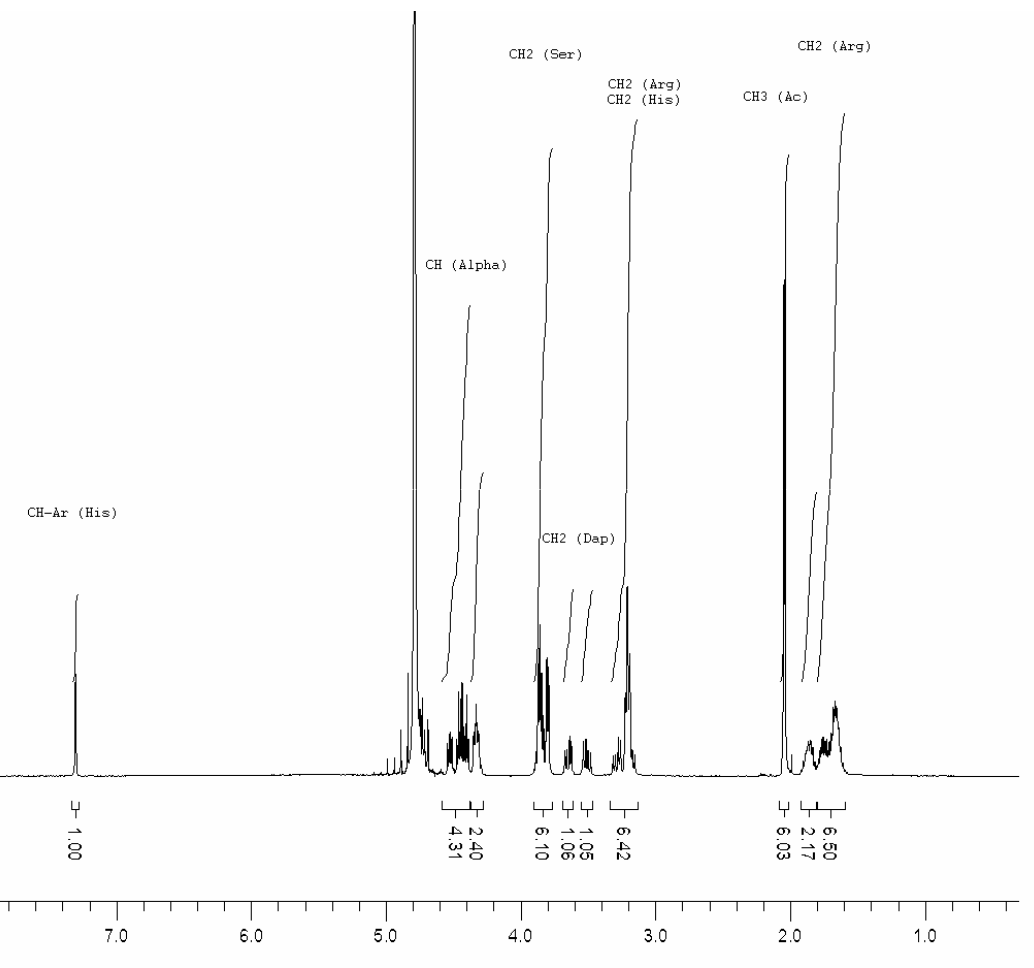


Preparative RP-HPLC: $t_{\mathrm{R}}=12 \mathrm{~min}(\mathrm{~A} / \mathrm{B}=100 / 0$ to $\mathrm{A} / \mathrm{B}=0 / 50$ in $50 \mathrm{~min})$

Analytical RP-HPLC: $t_{\mathrm{R}}=4.1 \mathrm{~min}(\mathrm{~A} / \mathrm{B}=100 / 0$ to $\mathrm{A} / \mathrm{B}=50 / 50$ in $10 \mathrm{~min})$

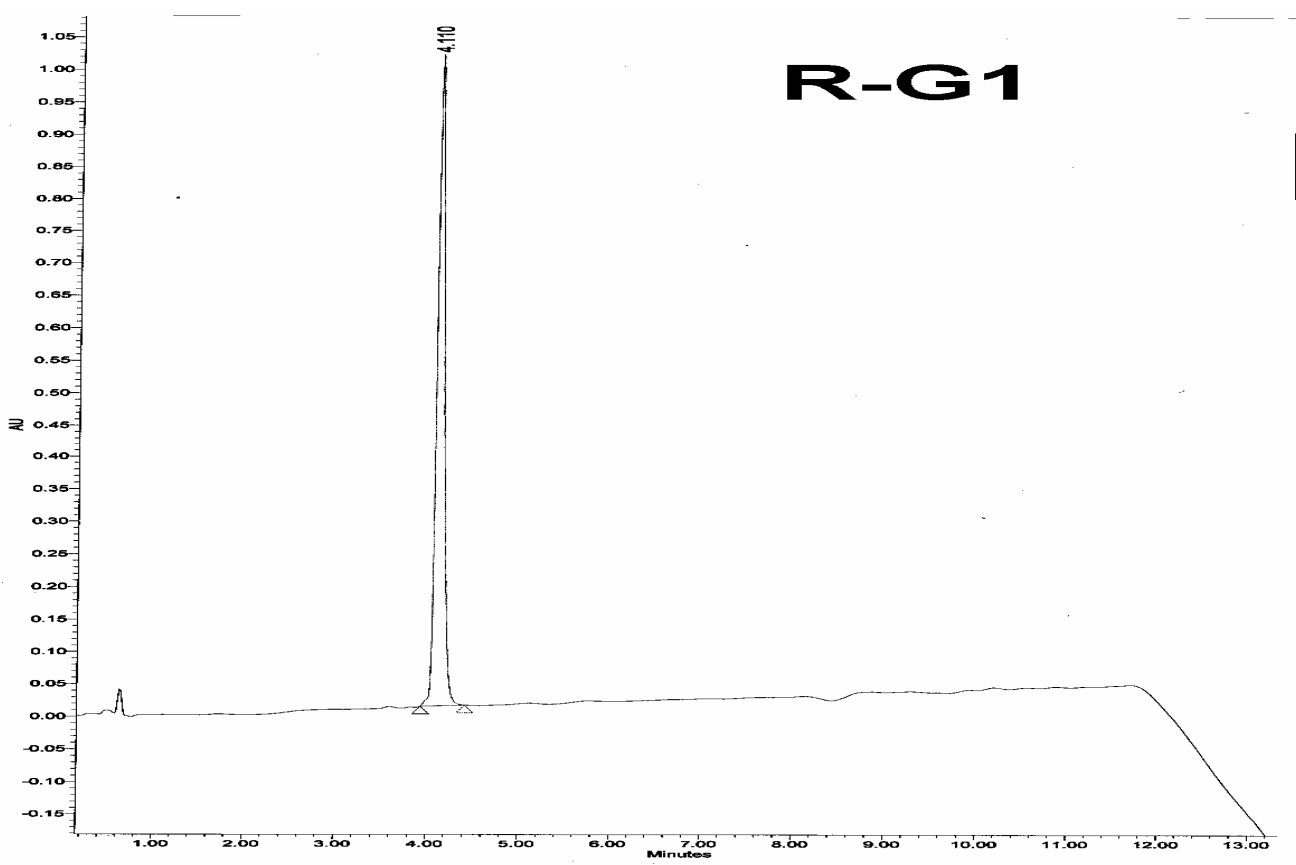

MS (ES+) calcd for $\mathrm{C}_{34} \mathrm{H}_{59} \mathrm{~N}_{17} \mathrm{O}_{12}[\mathrm{M}+\mathrm{H}]^{+}$: 898.5, found: 897.4; [M+K] $]^{+}$: 936.6, found: 935.0.

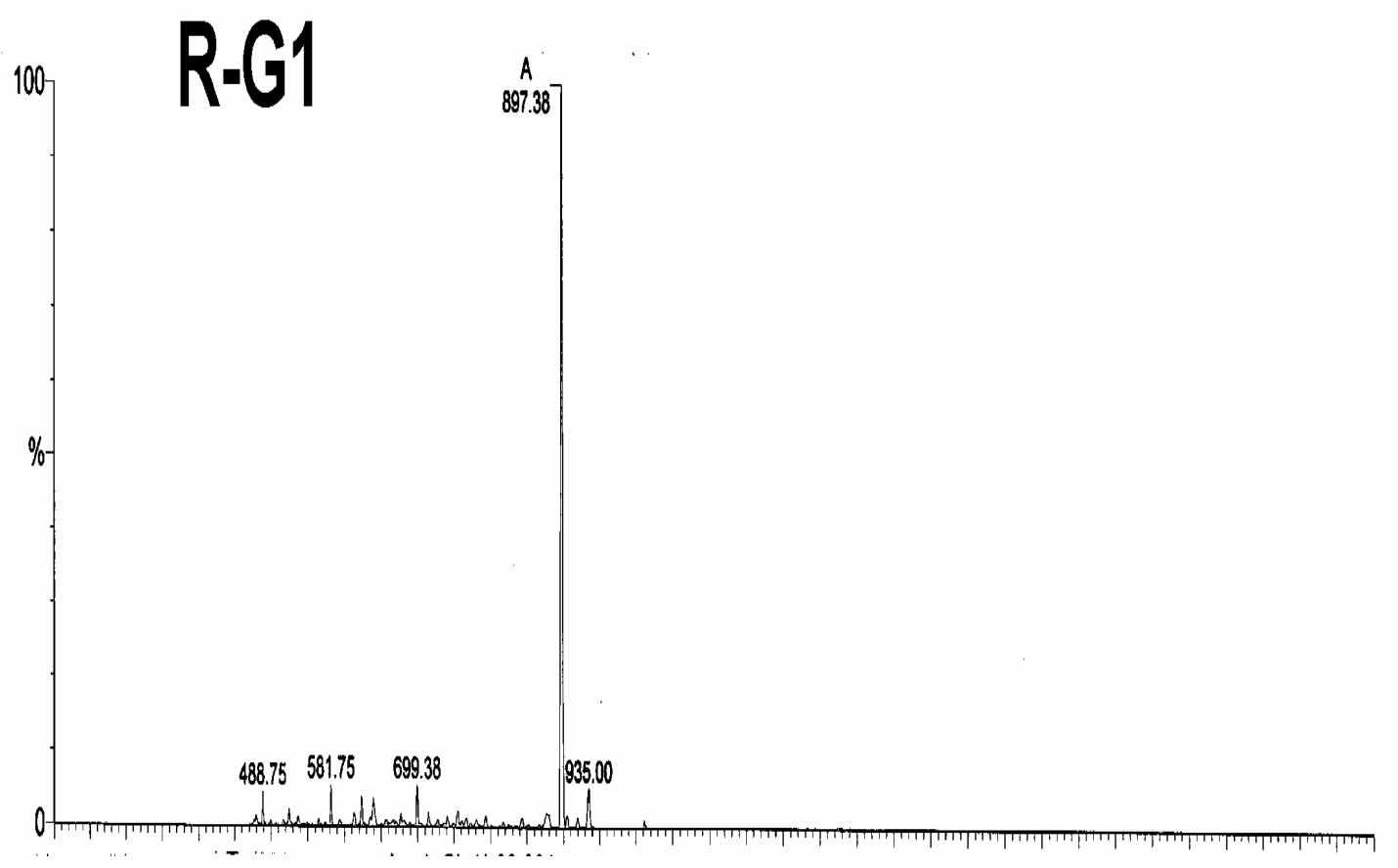


Michaelis-Menten plots for determination of $\boldsymbol{k}_{\text {cat }}$ and $\boldsymbol{K}_{\mathrm{M}}$
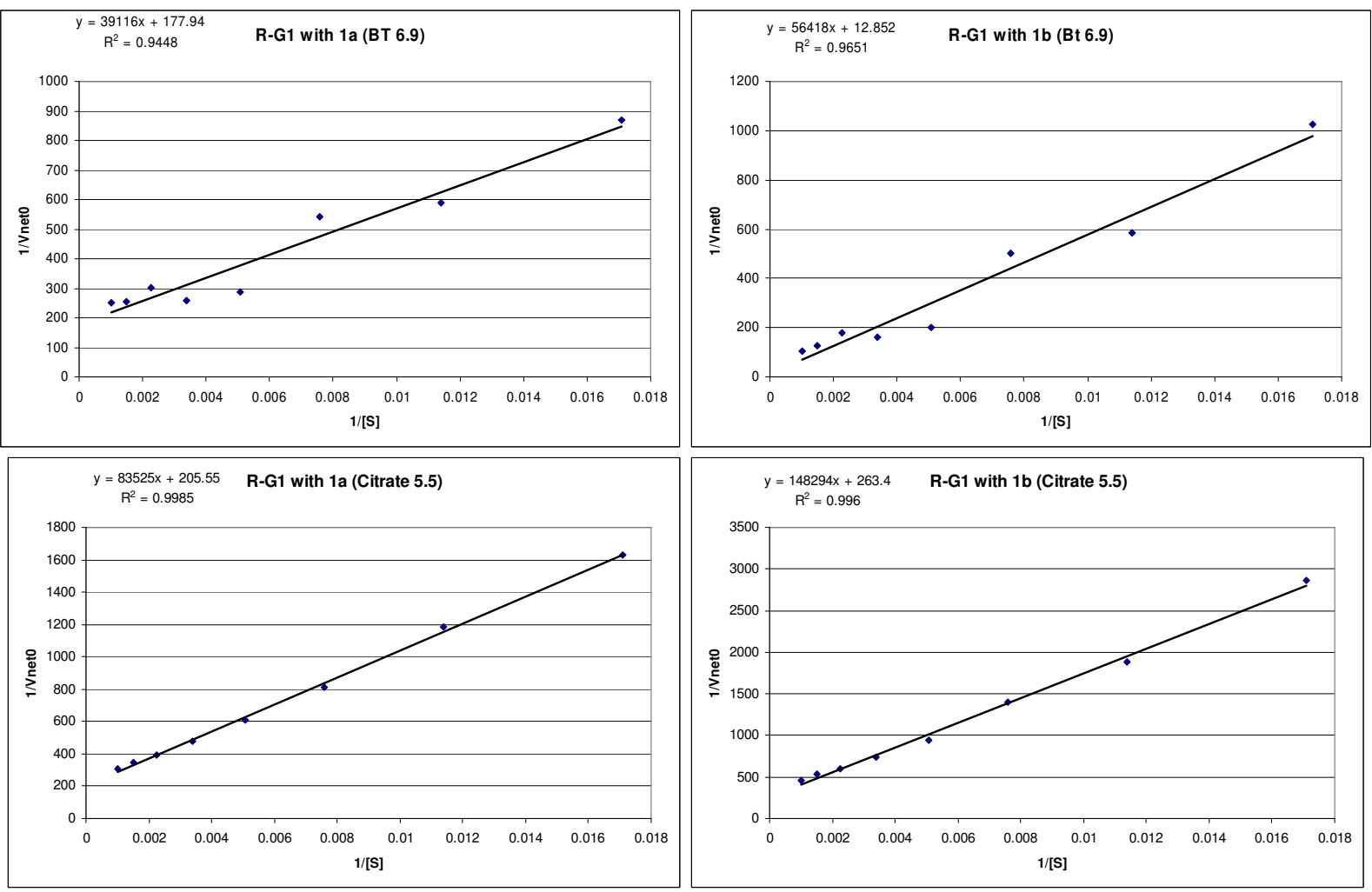


\section{Dendrimer R-G2: ((Ac-Trp-Gly $)_{2}$ Dap-Arg-Ser $)_{2}$ Dap-His-Ser- $\mathrm{NH}_{2}$}<smiles>CC(=O)N[C@@H](Cc1c[nH]c2ccccc12)C(=O)NCC(=O)NC[C@H](NC(=O)CNC(=O)[C@H](Cc1c[nH]c2ccccc12)NC(C)=O)C(=O)NCCCNC(=N)N</smiles>

Starting with $100 \mathrm{mg}$ of NovaSyn ${ }^{\circledR}$ TGR resin $(0.25 \mathrm{mmol} / \mathrm{g})$, the dendrimer R-G2 was obtained using procedure A as colorless foamy solid after cleavage from the resin and preparative RPHPLC purification $(3.3 \mathrm{mg}, 5.4 \%)$.

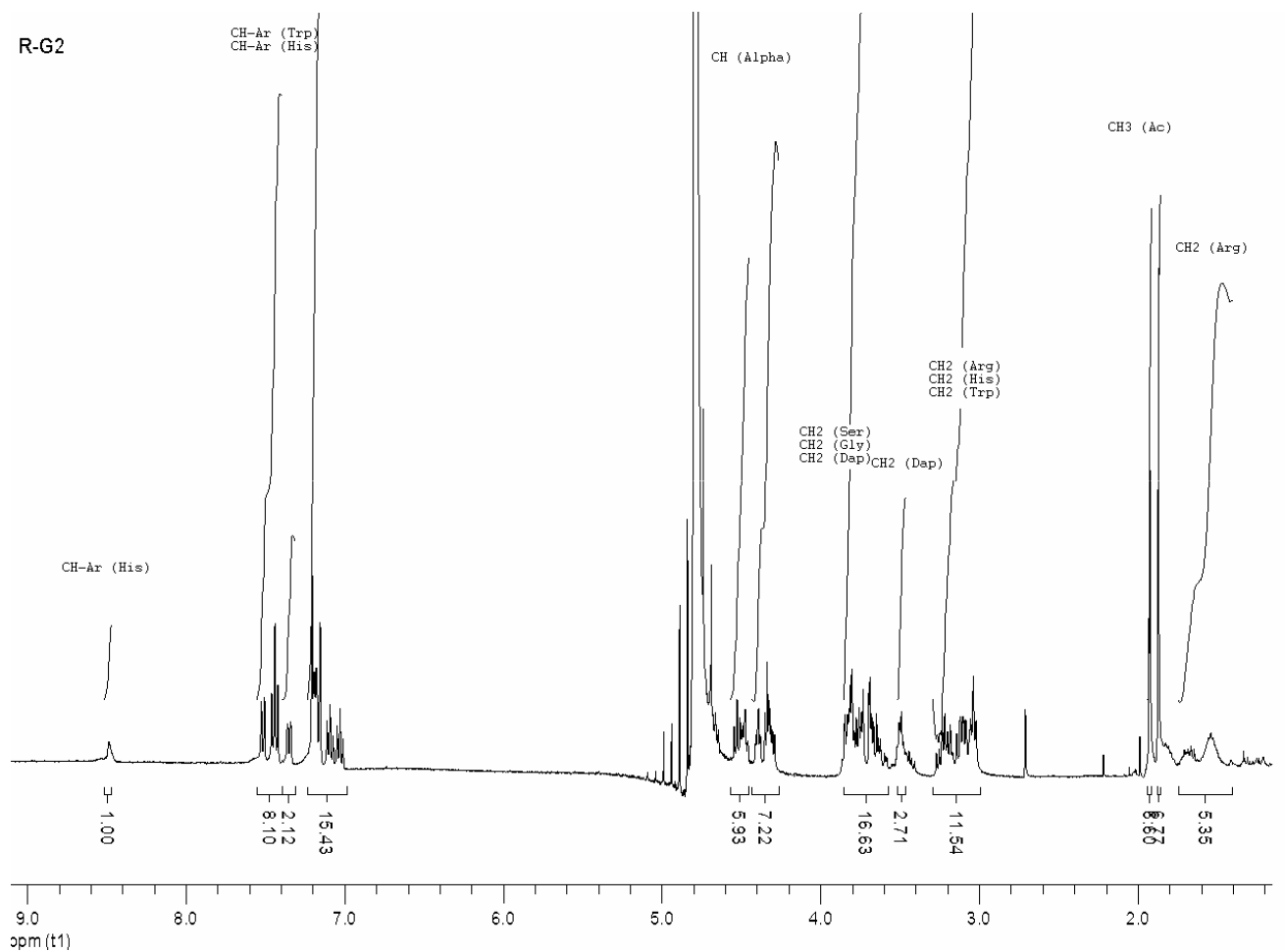


Preparative RP-HPLC: $t_{\mathrm{R}}=22 \min (\mathrm{A} / \mathrm{B}=70 / 30$ to $\mathrm{A} / \mathrm{B}=10 / 90$ in $60 \mathrm{~min})$

Analytical RP-HPLC: $t_{\mathrm{R}}=6.1 \mathrm{~min}(\mathrm{~A} / \mathrm{B}=70 / 30$ to $\mathrm{A} / \mathrm{B}=10 / 90$ in $10 \mathrm{~min})$

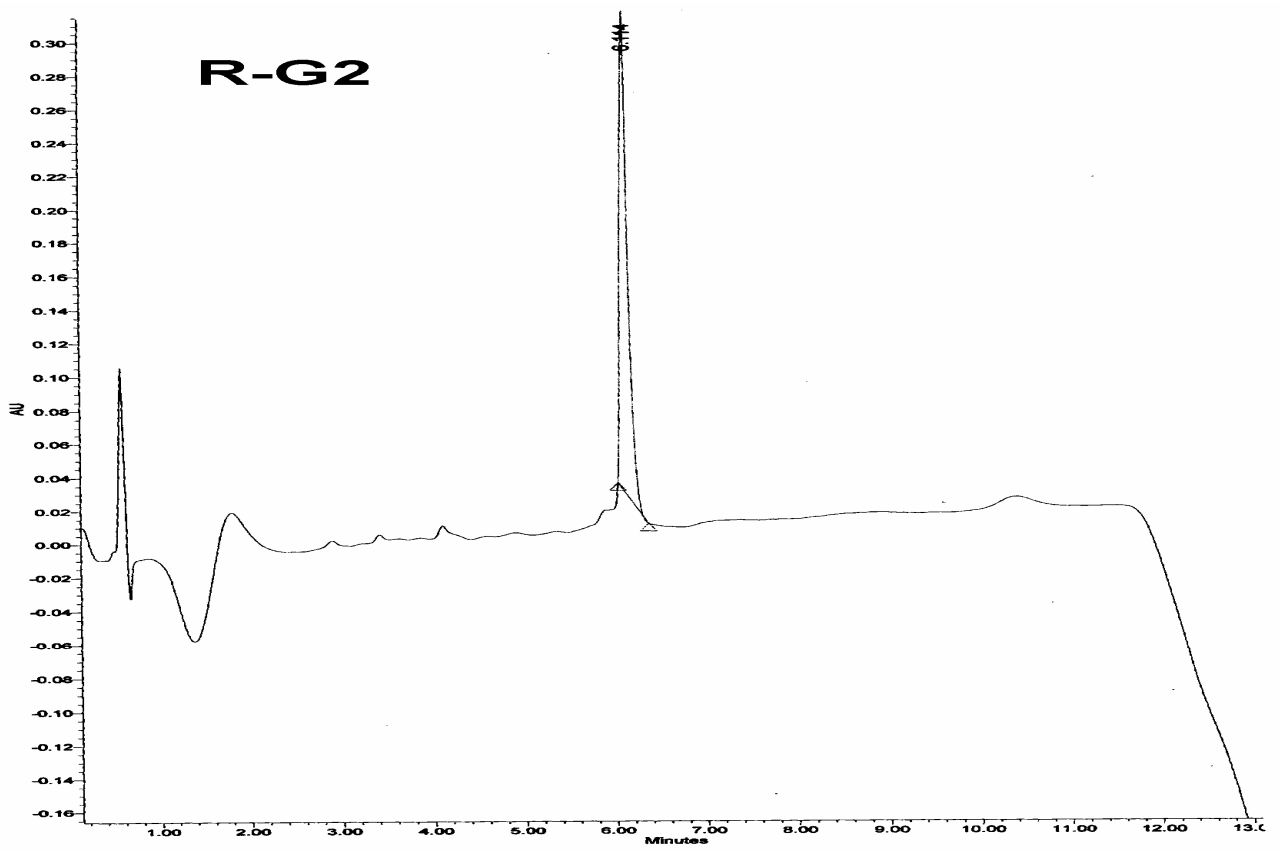

MS (ES+) calcd for $\mathrm{C}_{96} \mathrm{H}_{127} \mathrm{~N}_{33} \mathrm{O}_{24}[\mathrm{M}+\mathrm{H}]^{+}:$2127.0, found: 2126.8; [M+Na $]^{+}:$2149.0, found: 2148.8; $[\mathrm{M}+\mathrm{K}]^{+}:$2165.1, found: 2164.9.

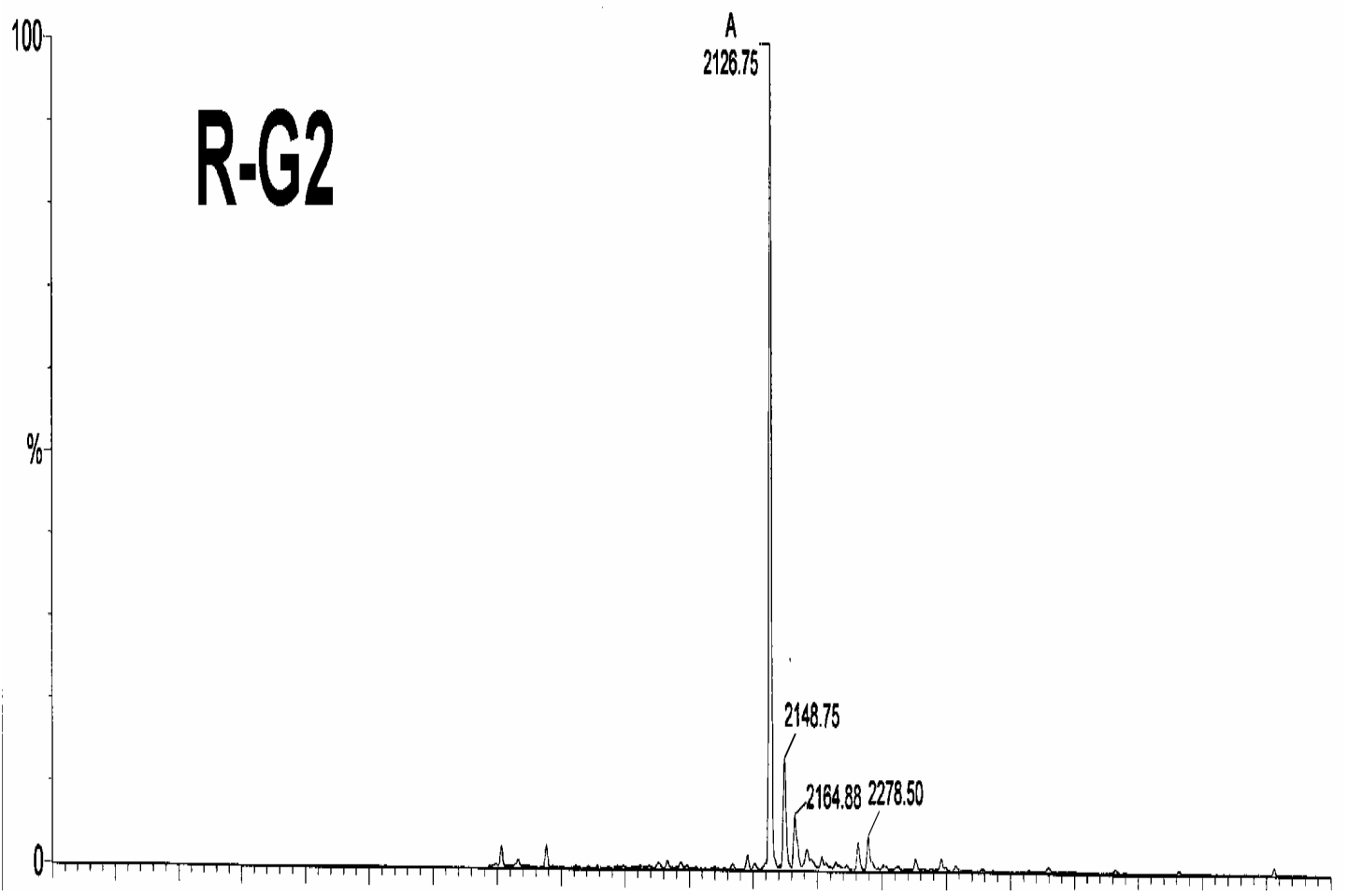


Michaelis-Menten plots for determination of $\boldsymbol{k}_{\text {cat }}$ and $\boldsymbol{K}_{\mathrm{M}}$
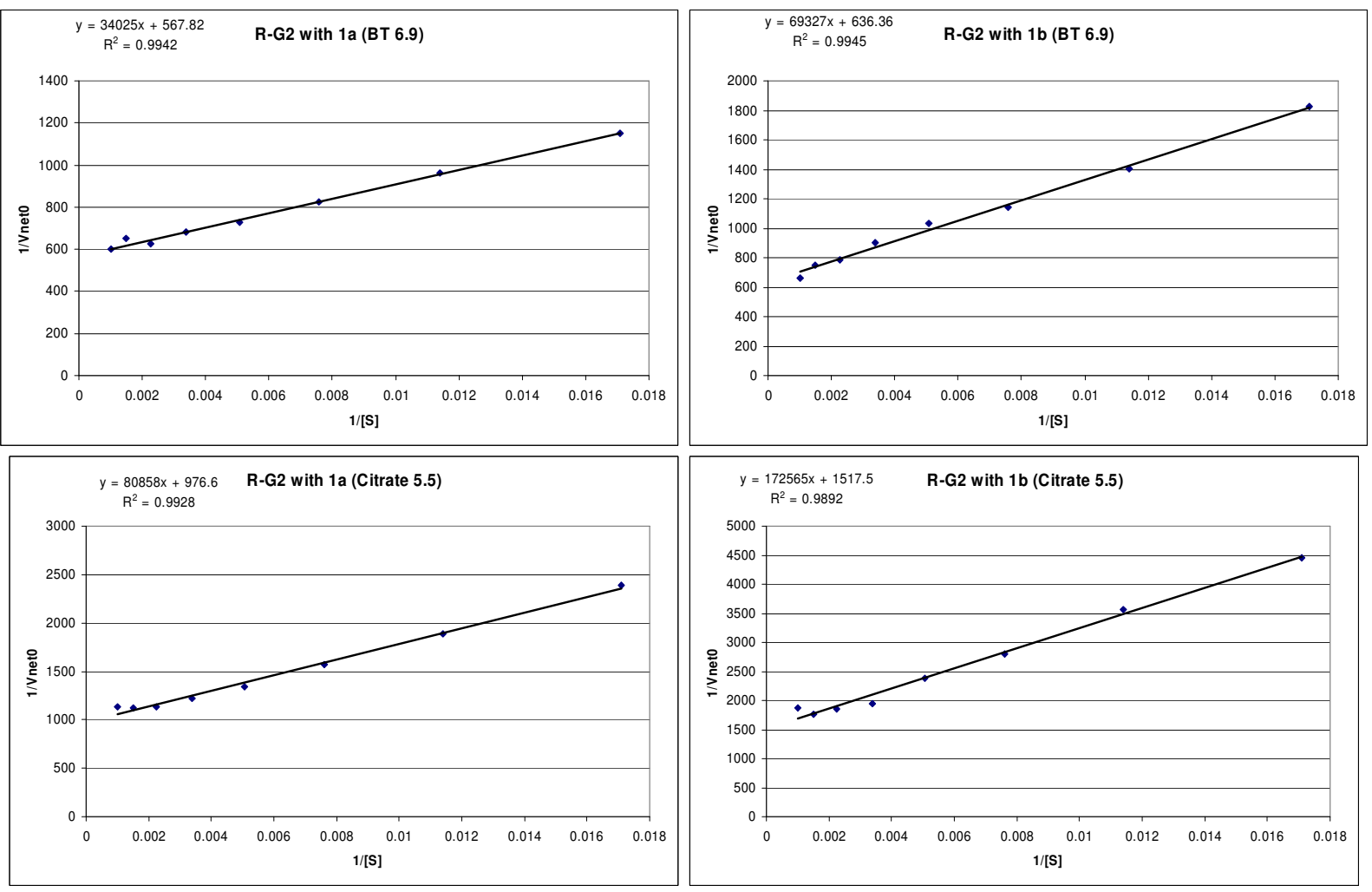


\section{Dendrimer R-G3: (((Ac-Tyr-Thr $)_{2}$ Dap-Trp-Gly $)_{2}$ Dap-Arg-Ser $)_{2}$ Dap-His-Ser-NH ${ }_{2}$}

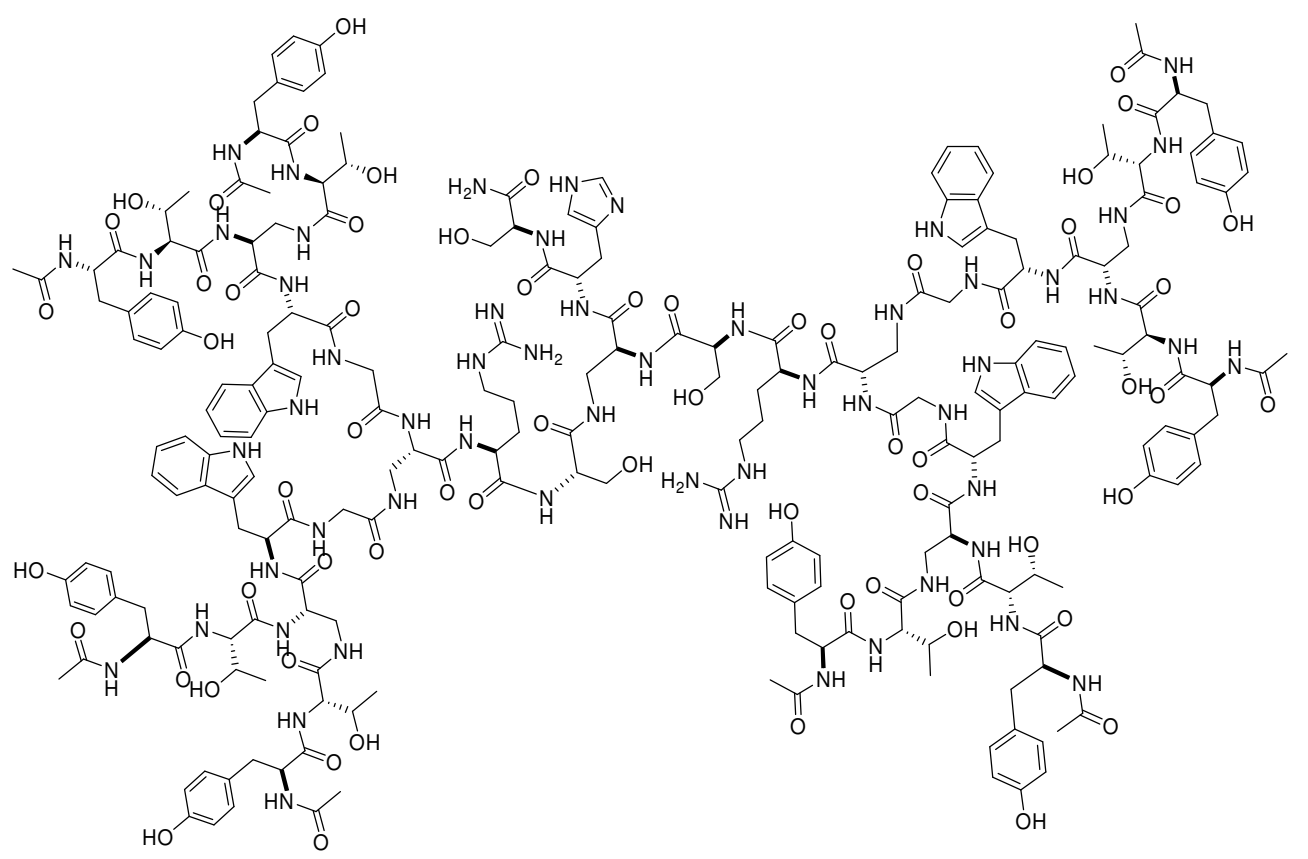

Starting with $250 \mathrm{mg}$ of NovaSyn ${ }^{\circledR}$ TGR resin $(0.26 \mathrm{mmol} / \mathrm{g})$, the dendrimer R-G3 was obtained as colorless foamy solid after cleavage from the resin and preparative RP-HPLC purification (5.5 $\mathrm{mg}, 1.7 \%)$.

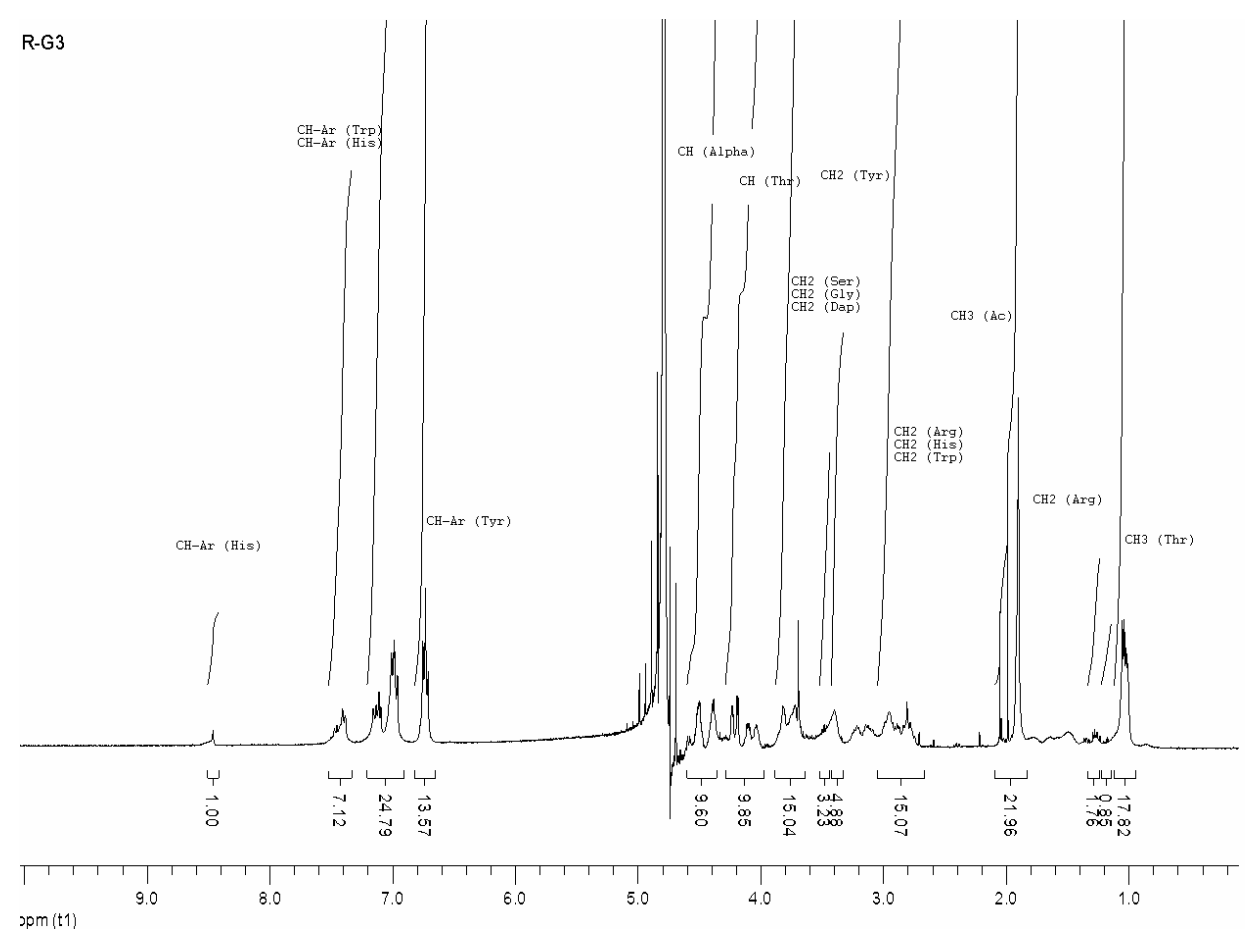


Preparative RP-HPLC: $t_{\mathrm{R}}=22 \min (\mathrm{A} / \mathrm{B}=70 / 30$ to $\mathrm{A} / \mathrm{B}=30 / 70$ in $40 \mathrm{~min})$

Analytical RP-HPLC: $t_{\mathrm{R}}=7.9 \mathrm{~min}(\mathrm{~A} / \mathrm{B}=70 / 30$ to $\mathrm{A} / \mathrm{B}=0 / 100$ in $15 \mathrm{~min})$

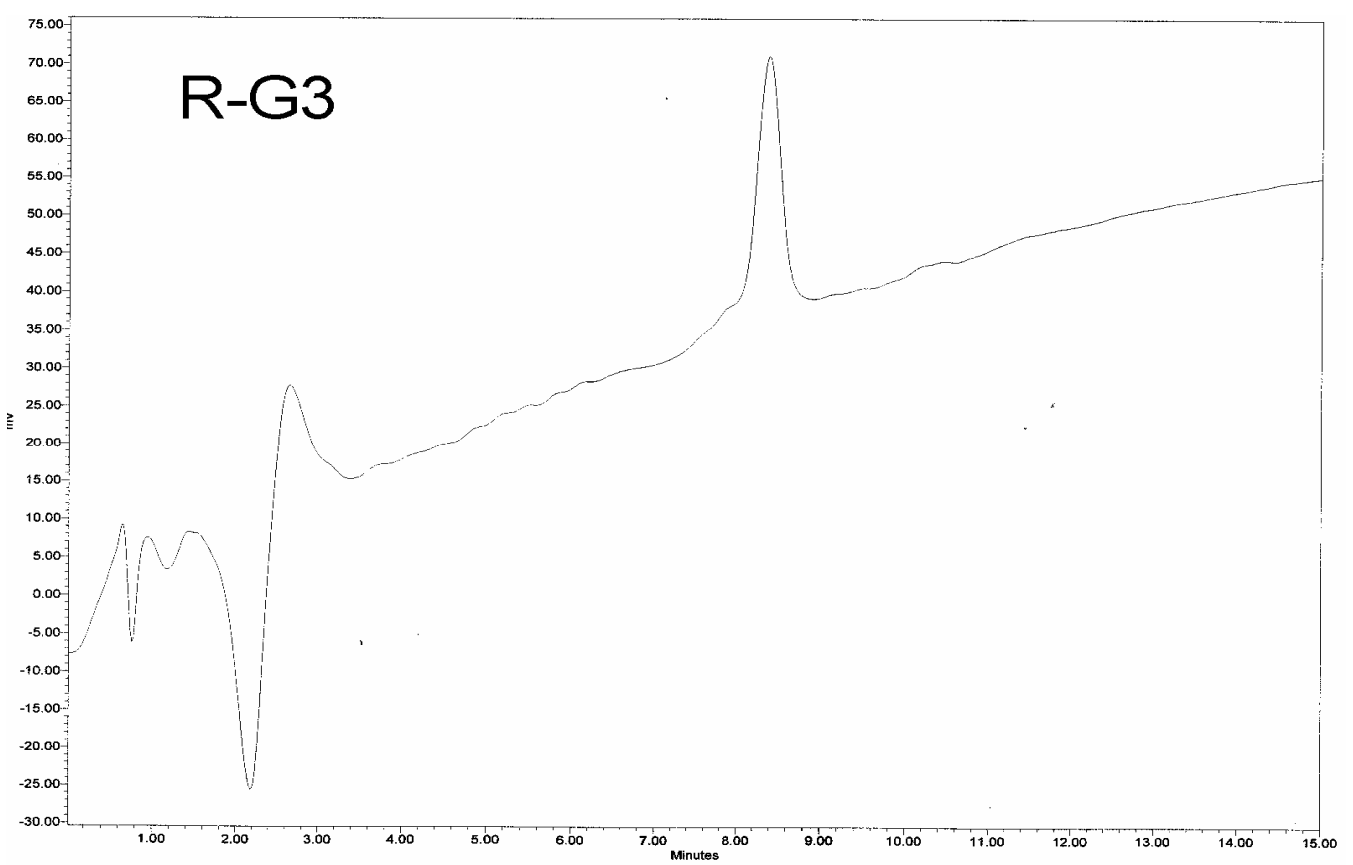

MS (ES+) calcd for $\mathrm{C}_{220} \mathrm{H}_{288} \mathrm{~N}_{57} \mathrm{O}_{64}[\mathrm{M}+\mathrm{H}]^{+}$: 4752.1, found: 4754.4; [M+Na] $]^{+}$: 4777.1, found: 4777.2; $[\mathrm{M}+\mathrm{K}]^{+}:$4790.2, found: 4793.5 .

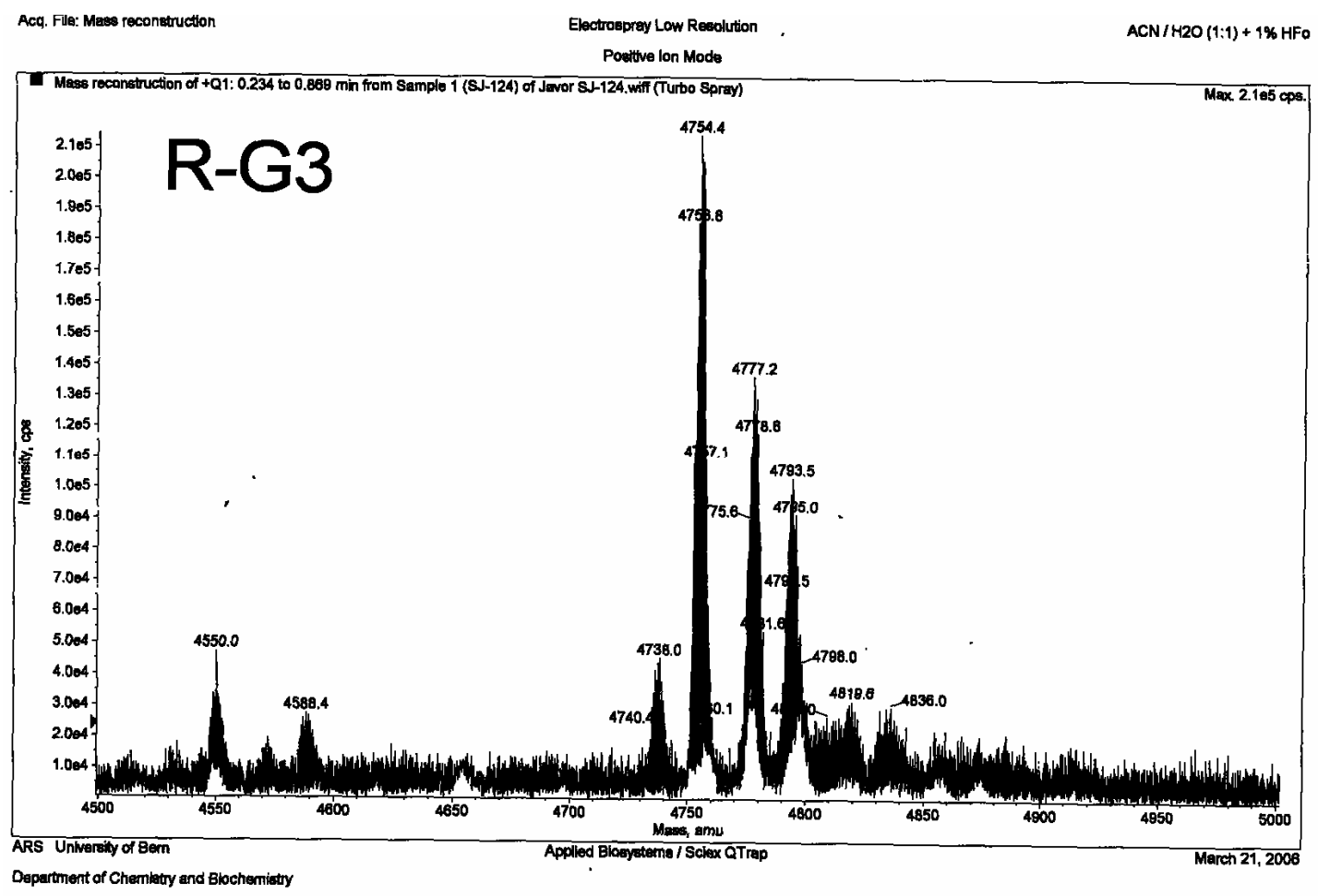


Michaelis-Menten plots for determination of $\boldsymbol{k}_{c a t}$ and $\boldsymbol{K}_{M}$
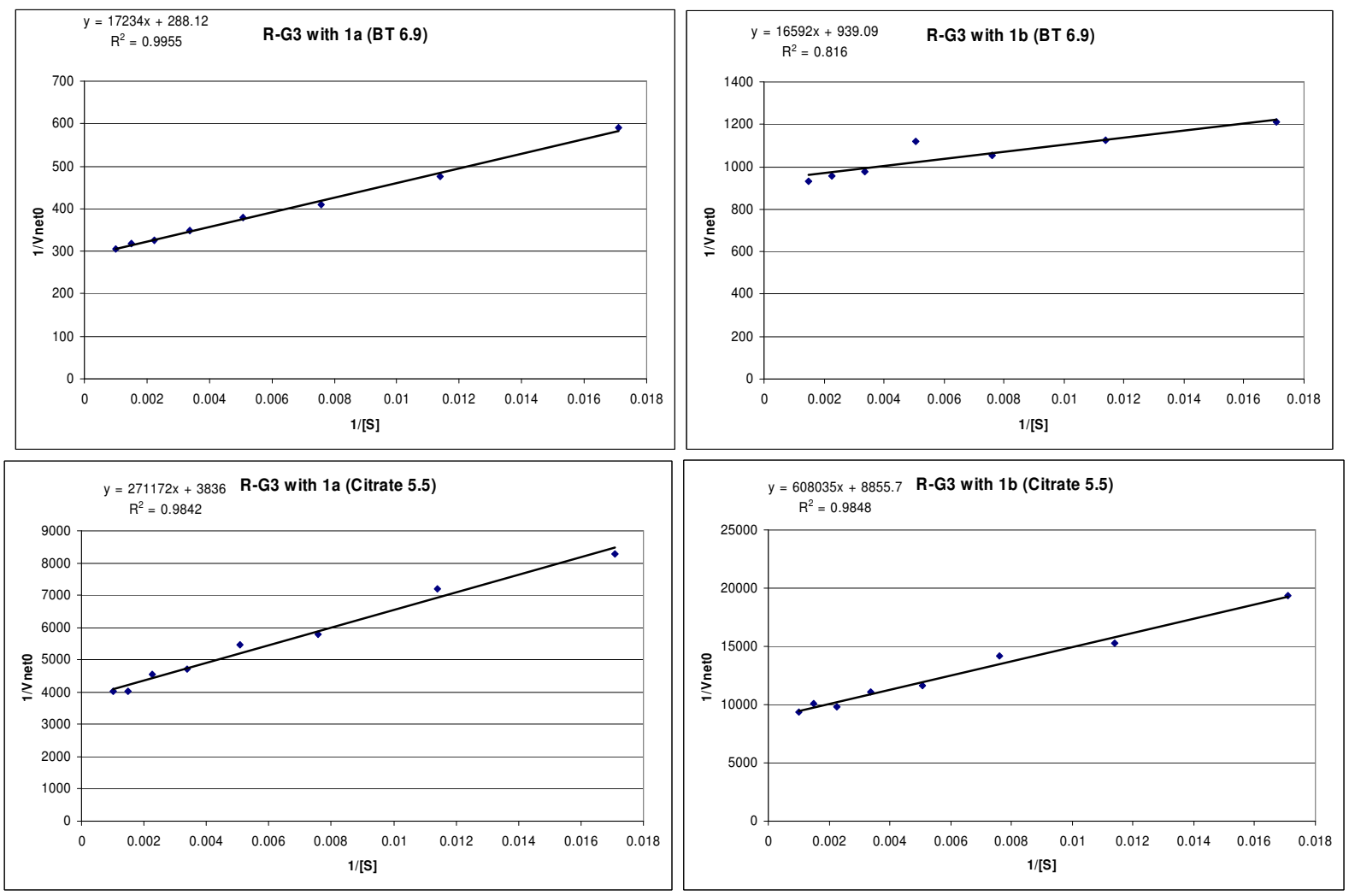


\section{Peptide RM-G0: Ac-Arg-Ser-Gly-Ala-His-Ser-NH}

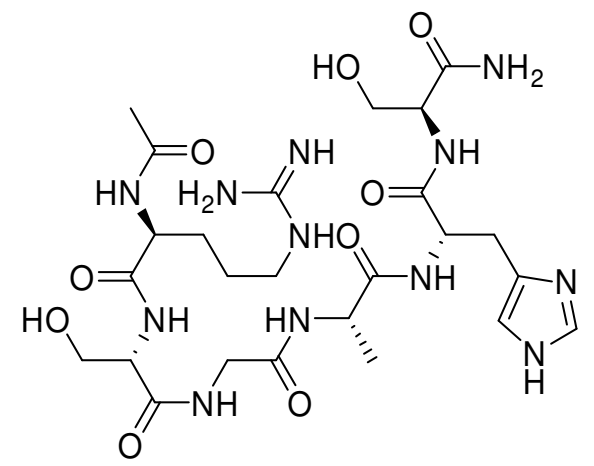

Starting with $250 \mathrm{mg}$ of Rink amide Novagel resin $(0.63 \mathrm{mmol} / \mathrm{g})$, the peptide RM-G0 was obtained using procedure B as colorless solid after cleavage from the resin and preparative RPHPLC purification ( $70.4 \mathrm{mg}, 50.6 \%$ ).

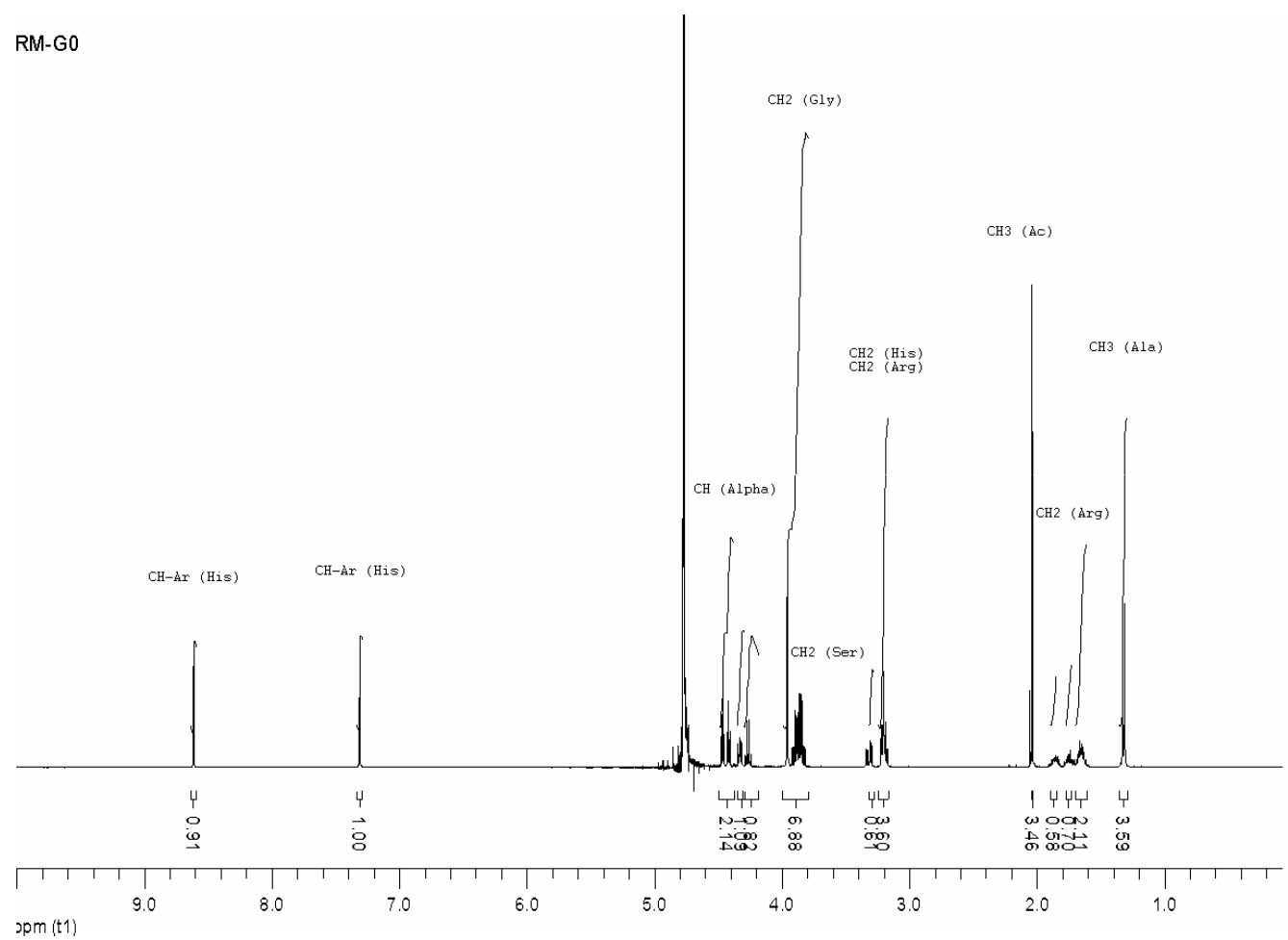


Preparative RP-HPLC: $t_{\mathrm{R}}=9.0 \mathrm{~min}(\mathrm{~A} / \mathrm{B}=100 / 0$ to $\mathrm{A} / \mathrm{B}=70 / 30$ in $30 \mathrm{~min})$

Analytical RP-HPLC: $t_{\mathrm{R}}=2.9 \mathrm{~min}(\mathrm{~A} / \mathrm{B}=100 / 0$ to $\mathrm{A} / \mathrm{B}=0 / 100$ in $10 \mathrm{~min})$

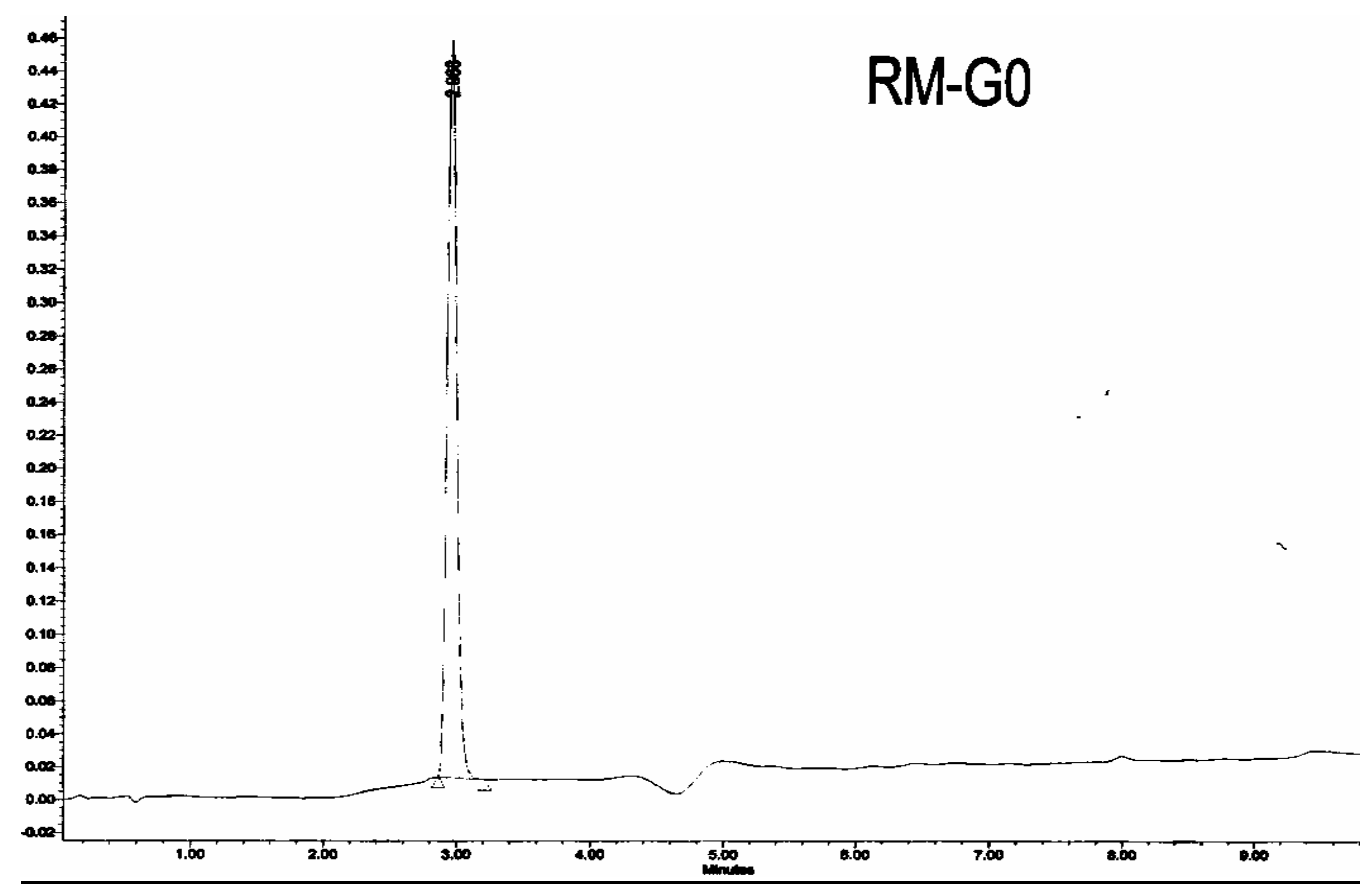

MS (ES+) calcd for $\mathrm{C}_{25} \mathrm{H}_{42} \mathrm{~N}_{12} \mathrm{O}_{9}[\mathrm{M}+\mathrm{H}]^{+}: 655.3$, found: $655.4 ;[\mathrm{M}+2 \mathrm{H}]^{2+}: 328.2$, found: 328.2 .

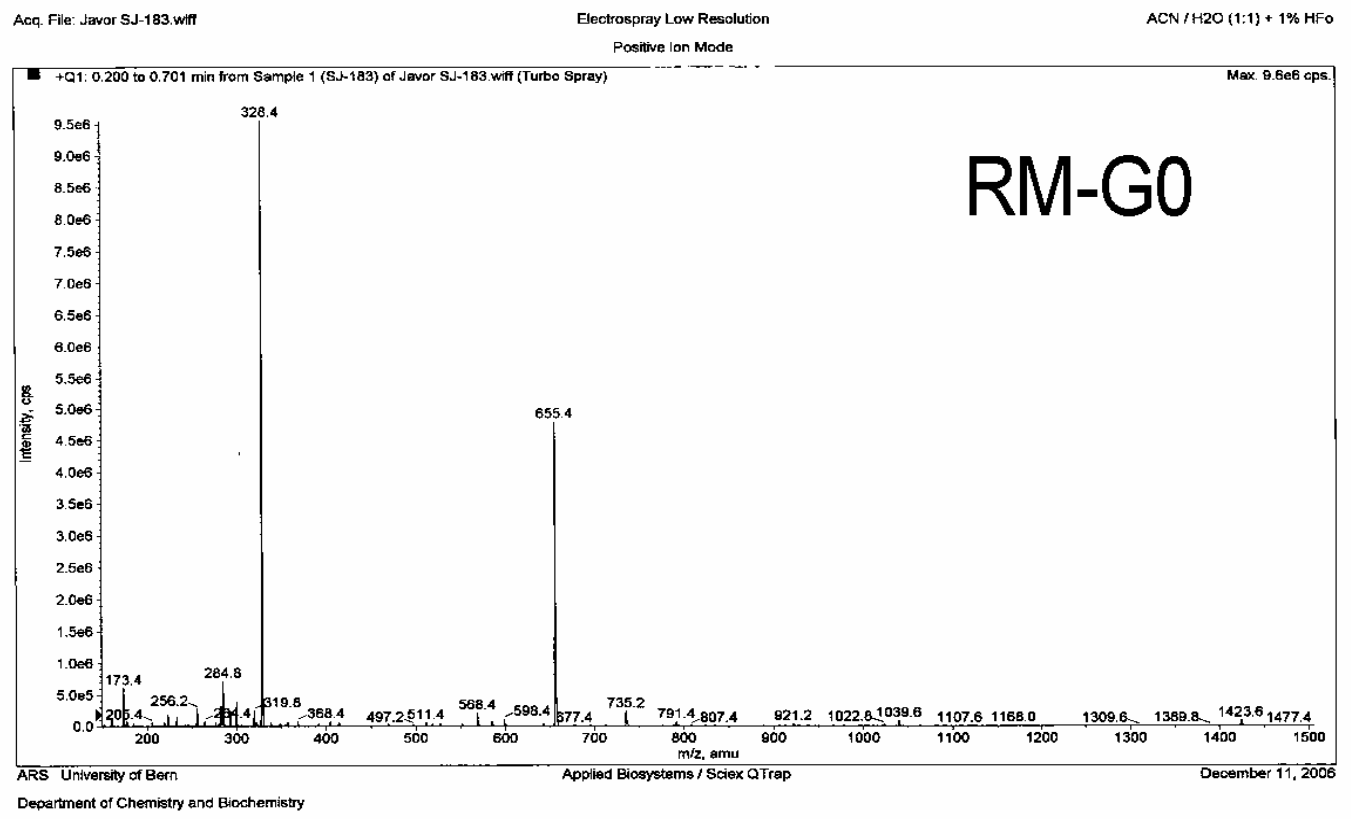


Michaelis-Menten plots for determination of $\boldsymbol{k}_{\text {cat }}$ and $\boldsymbol{K}_{\mathrm{M}}$
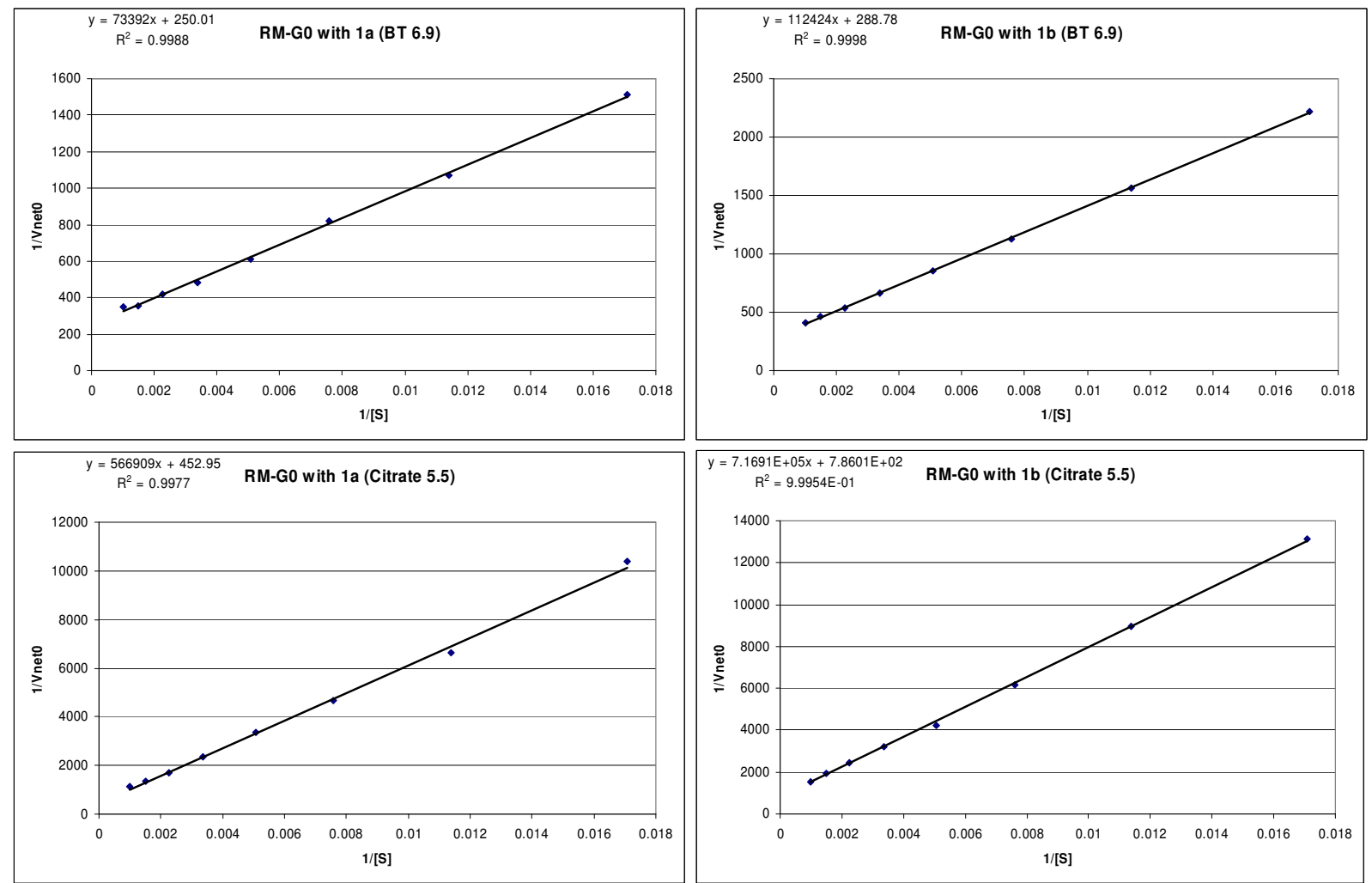


\section{Dendrimer RM-G1: (Ac-Arg-Ser-Gly) ${ }_{2}$ Dap-His-Ser-NH 2}

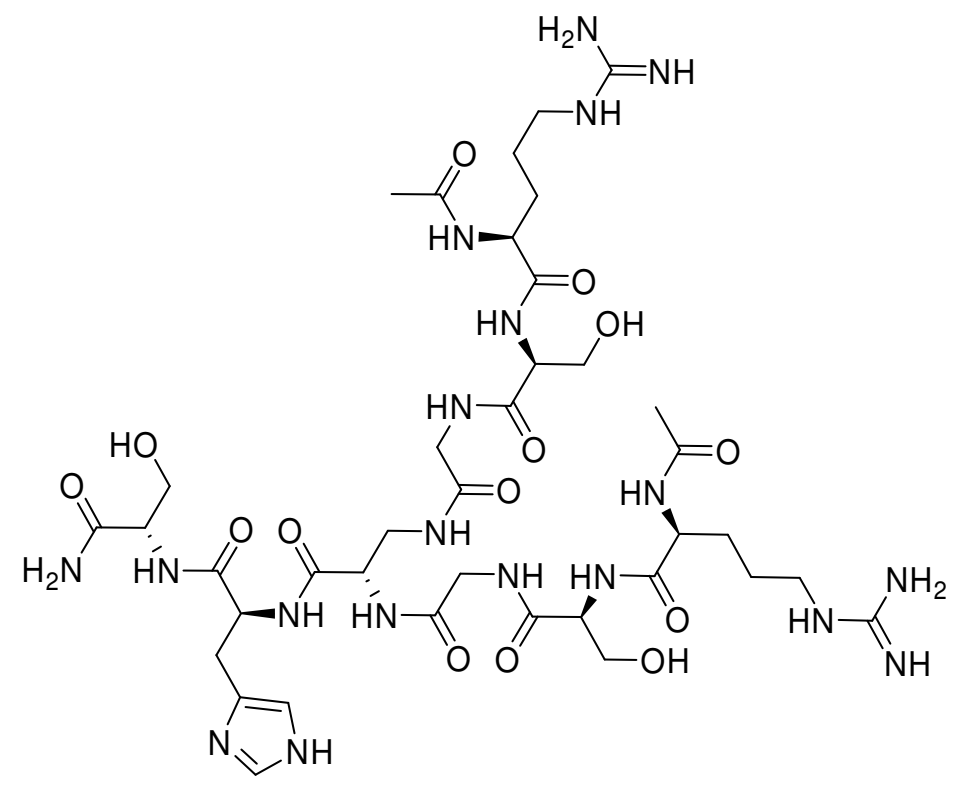

Starting with $250 \mathrm{mg}$ of NovaSyn ${ }^{\circledR}$ TGR resin $(0.23 \mathrm{mmol} / \mathrm{g})$, the dendrimer RM-G1 was obtained using procedure A as colorless foamy solid after cleavage from the resin and preparative RP-HPLC purification (40.4 mg, $51.9 \%$ ).

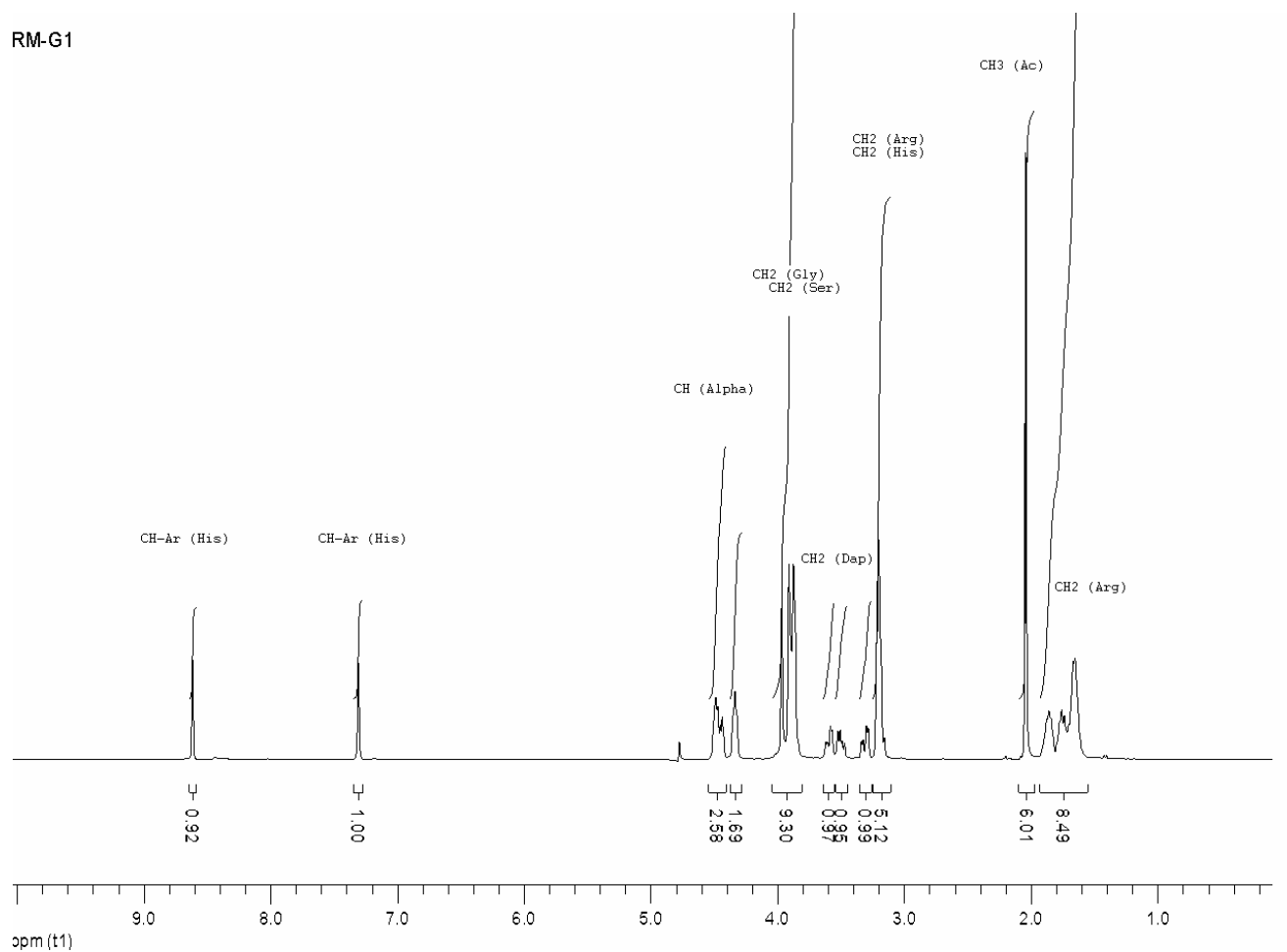


Preparative RP-HPLC: $t_{\mathrm{R}}=14 \mathrm{~min}(\mathrm{~A} / \mathrm{B}=100 / 0$ to $\mathrm{A} / \mathrm{B}=70 / 30$ in $30 \mathrm{~min})$

Analytical RP-HPLC: $t_{\mathrm{R}}=4.0 \mathrm{~min}(\mathrm{~A} / \mathrm{B}=100 / 0$ to $\mathrm{A} / \mathrm{B}=60 / 40$ in $8.0 \mathrm{~min})$

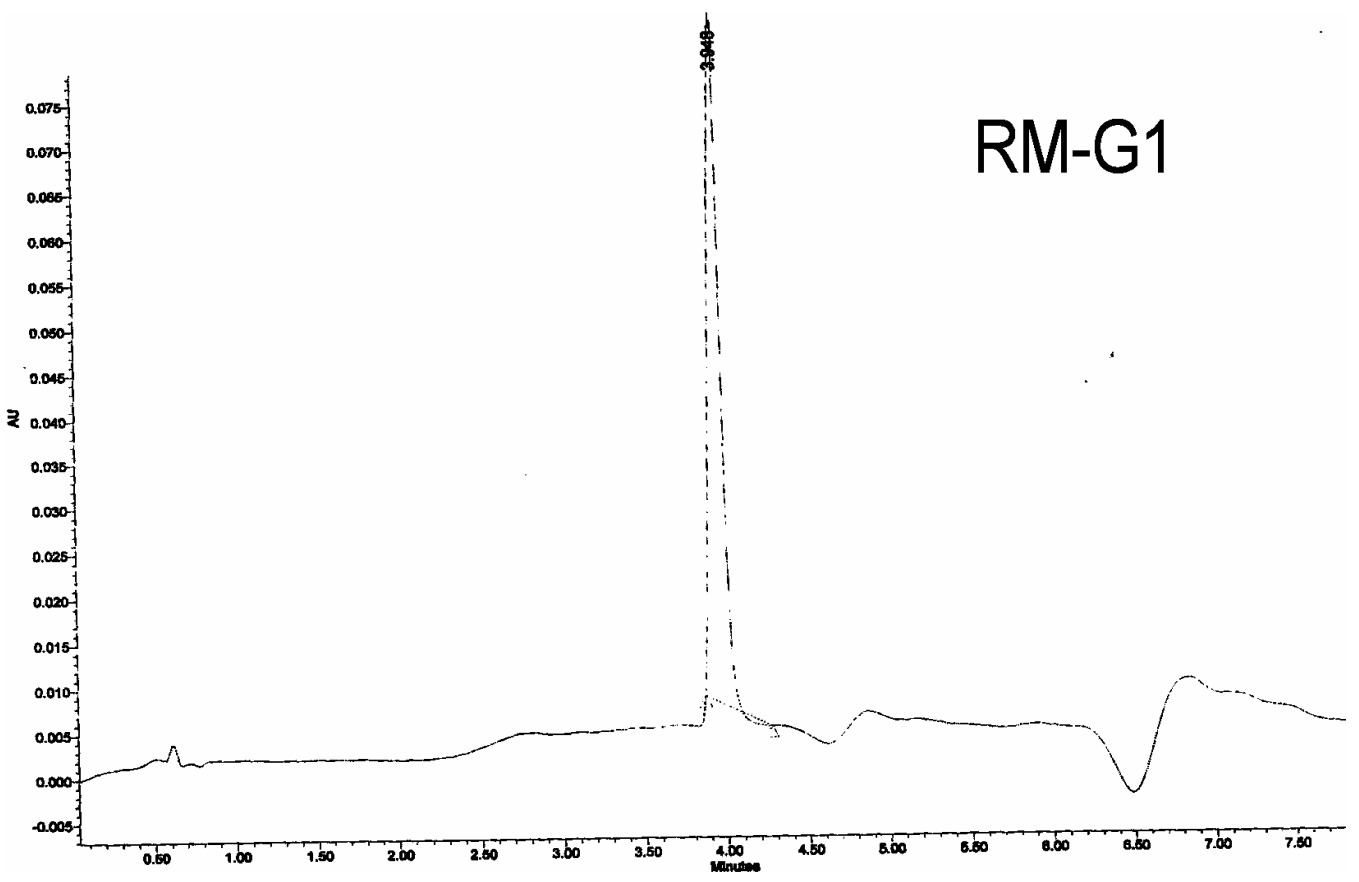

MS (ES+) calcd for $\mathrm{C}_{38} \mathrm{H}_{66} \mathrm{~N}_{19} \mathrm{O}_{14}[\mathrm{M}+\mathrm{H}]^{+}: 1012.5$, found: $1012.8 ;[\mathrm{M}+2 \mathrm{H}]^{2+} / 2: 506.2$, found: 507.0; $[\mathrm{M}+3 \mathrm{H}]^{3+} / 3: 338.2$, found: $338.4 ;[\mathrm{M}+\mathrm{TFA}]^{+}: 1125.5$, found: 1125.8 .

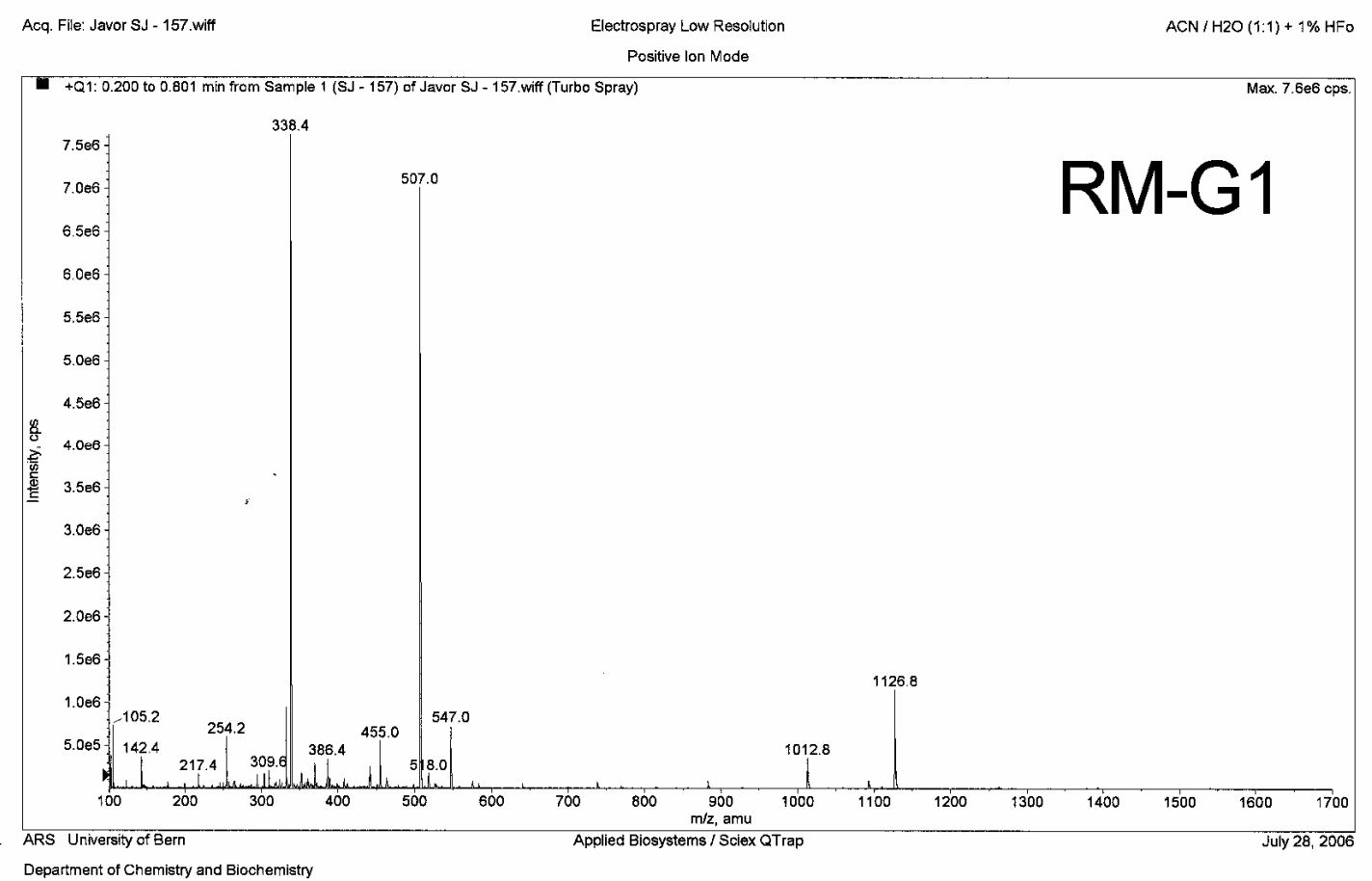


Michaelis-Menten plots for determination of $\boldsymbol{k}_{\text {cat }}$ and $\boldsymbol{K}_{\mathrm{M}}$
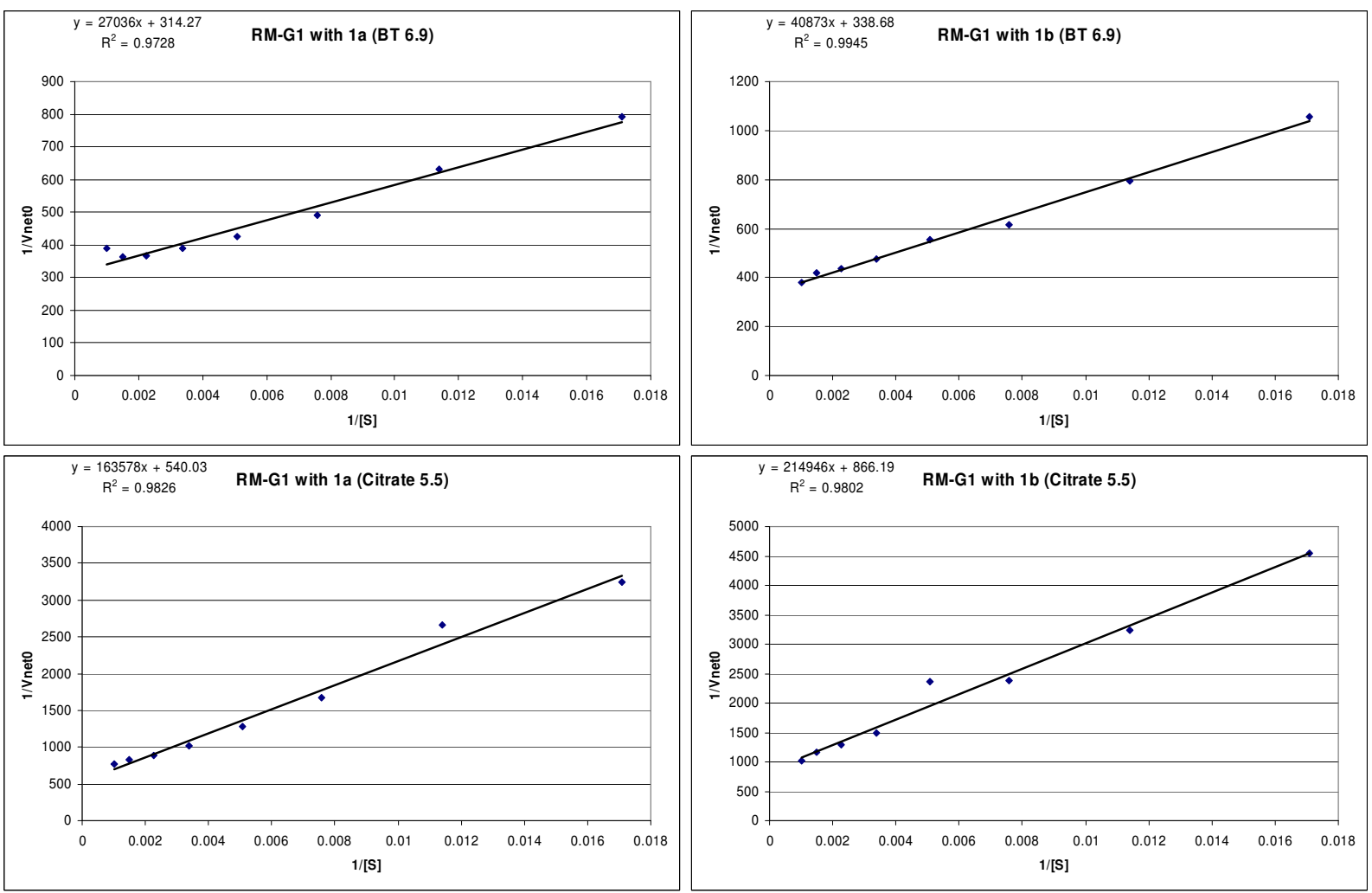


\section{Dendrimer RM-G2: ((Ac-Trp-Gly $)_{2}$ Dap-Arg-Ser-Gly $)_{2}$ Dap-His-Ser-NH ${ }_{2}$}

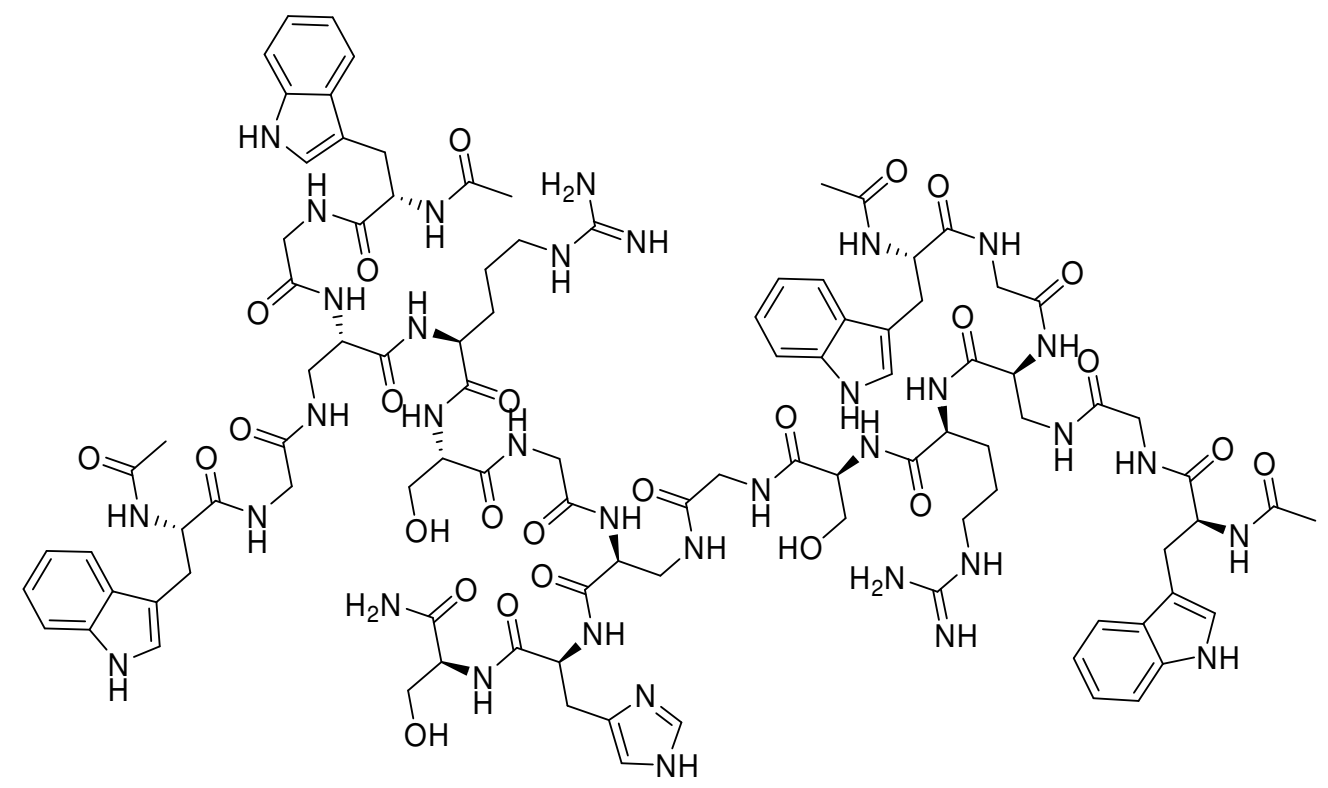

Starting with $250 \mathrm{mg}$ of NovaSyn ${ }^{\circledR}$ TGR resin $(0.23 \mathrm{mmol} / \mathrm{g})$, the dendrimer RM-G2 was obtained using procedure A as colorless foamy solid after cleavage from the resin and preparative RP-HPLC purification (7.7 mg, $5.2 \%)$.

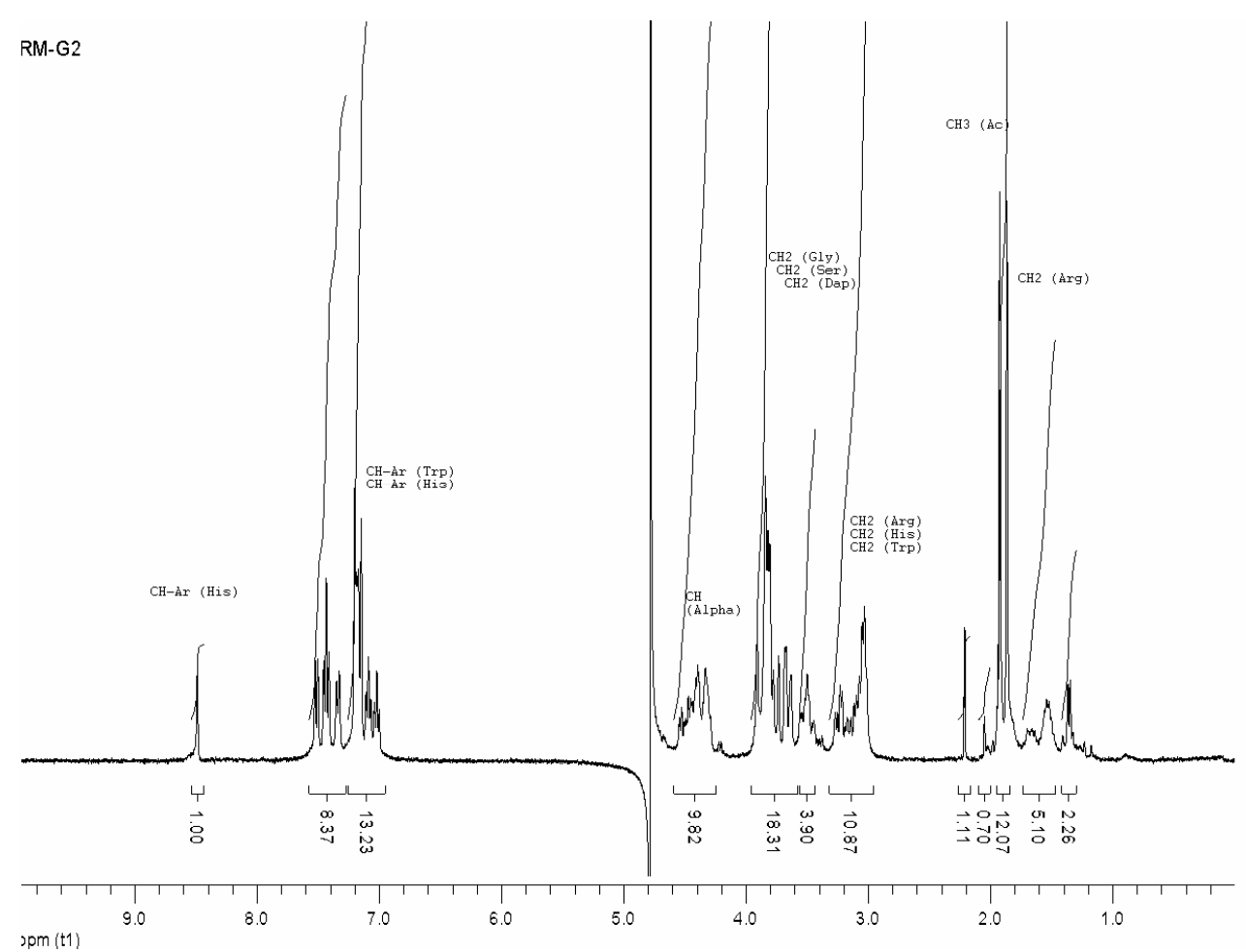


Preparative RP-HPLC: $t_{\mathrm{R}}=21 \mathrm{~min}(\mathrm{~A} / \mathrm{B}=70 / 30$ to $\mathrm{A} / \mathrm{B}=30 / 70$ in $40 \mathrm{~min})$

Analytical RP-HPLC: $t_{\mathrm{R}}=7.5 \min (\mathrm{A} / \mathrm{B}=70 / 30$ to $\mathrm{A} / \mathrm{B}=0 / 100$ in $15 \mathrm{~min})$

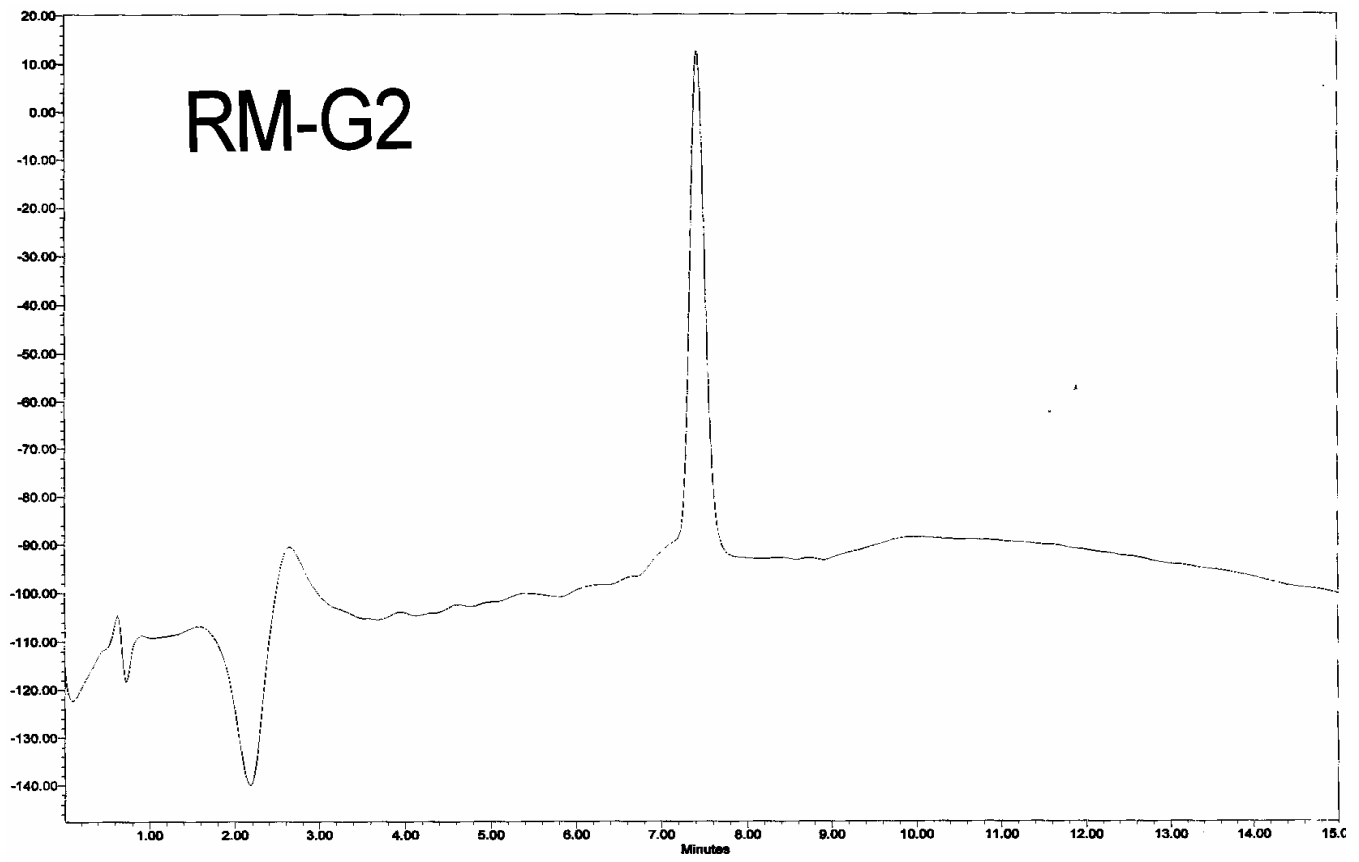

MS (ES+) calcd for $\mathrm{C}_{224} \mathrm{H}_{294} \mathrm{~N}_{59} \mathrm{O}_{66}[\mathrm{M}+\mathrm{H}]^{+}:$2241.0, found: 2241.5; [M+Na] $]^{+}: 2263.0$, found: 2264.0; [M+K $]^{+}:$2279.9, found: 2280.0 .

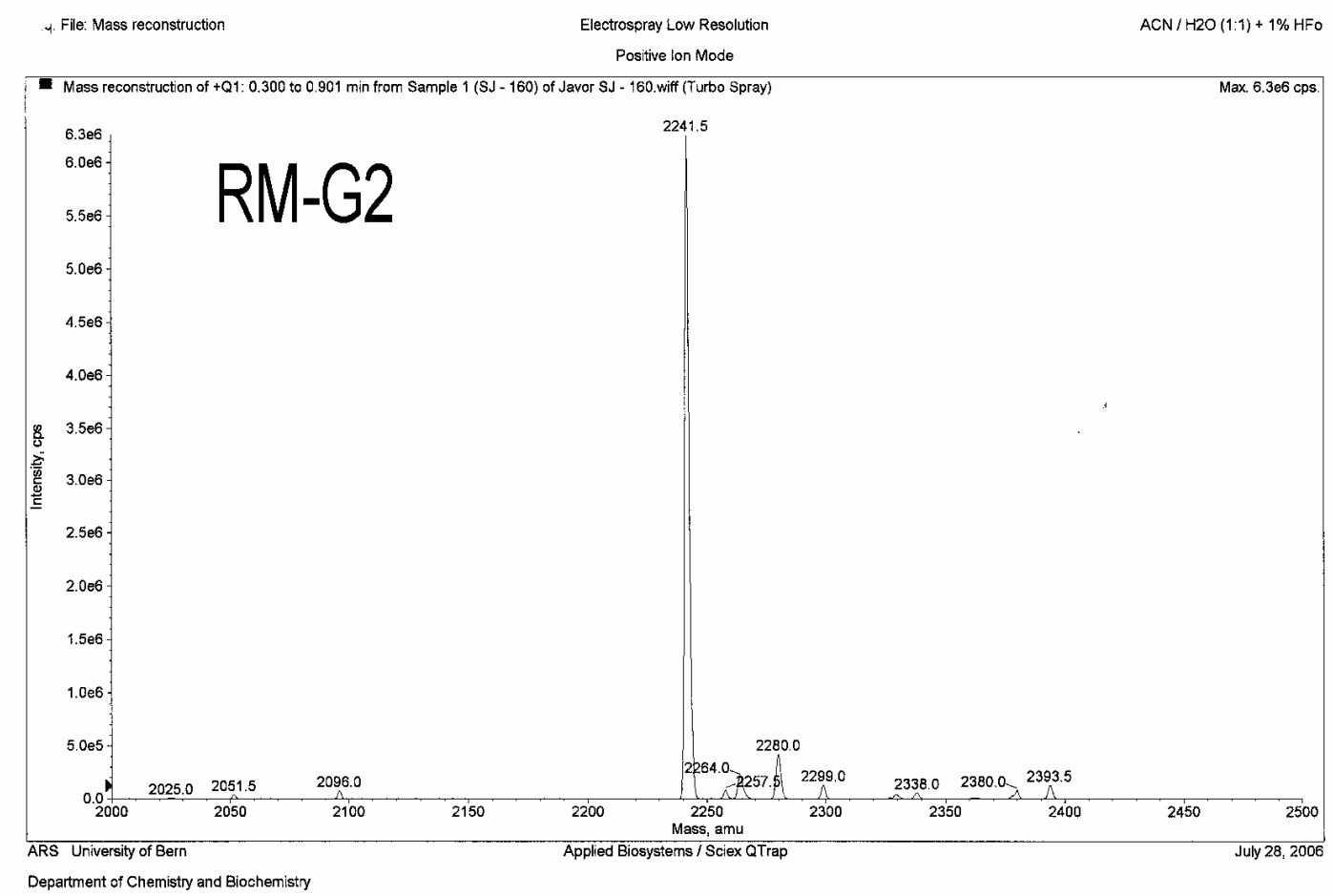


Michaelis-Menten plots for determination of $\boldsymbol{k}_{\text {cat }}$ and $\boldsymbol{K}_{\mathrm{M}}$
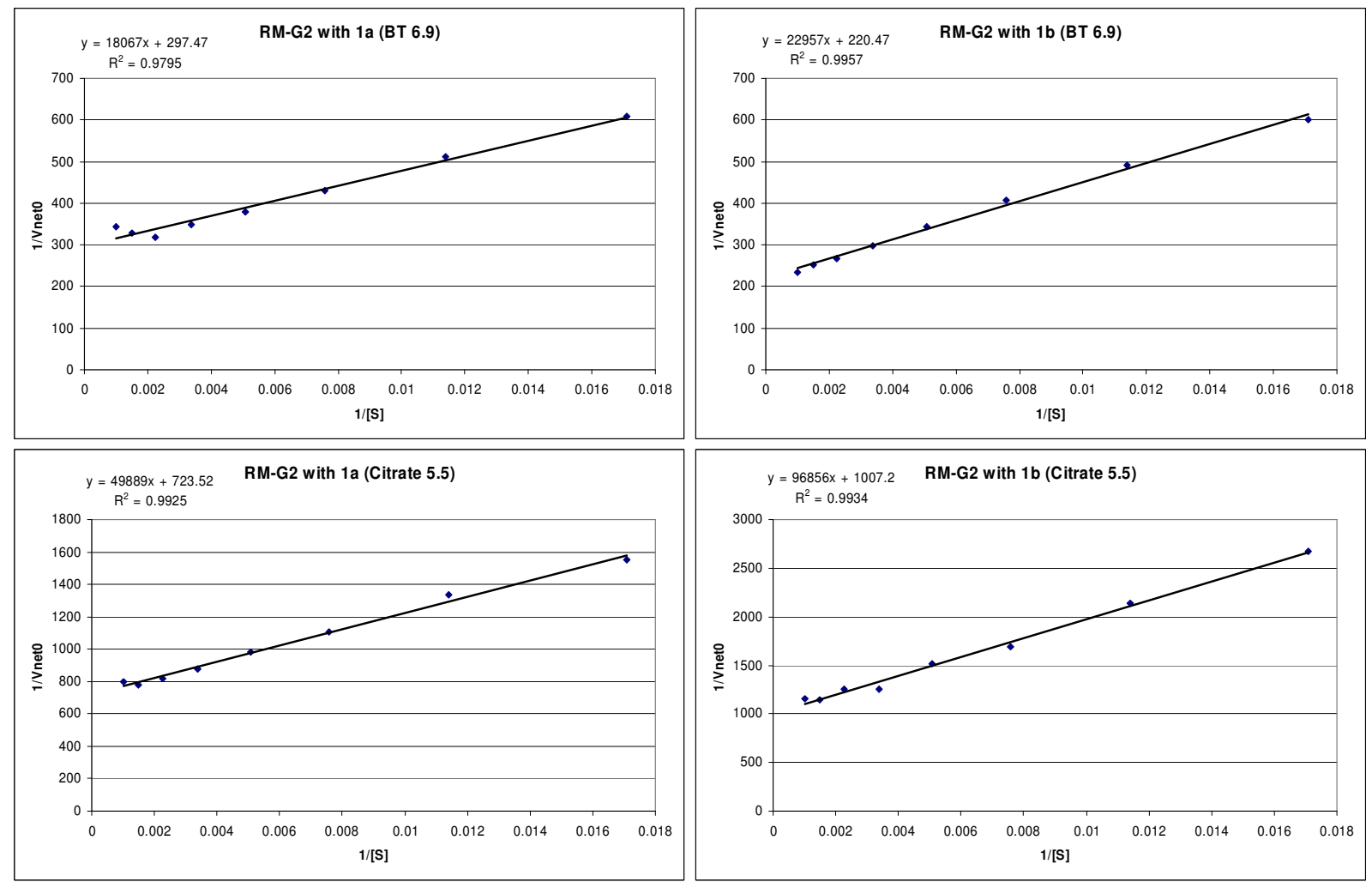


\section{Dendrimer RM-G3: (((Ac-Tyr-Thr $)_{2}$ Dap-Trp-Gly $)_{2}$ Dap-Arg-Ser-Gly $)_{2}$ Dap-His-Ser-NH ${ }_{2}$}

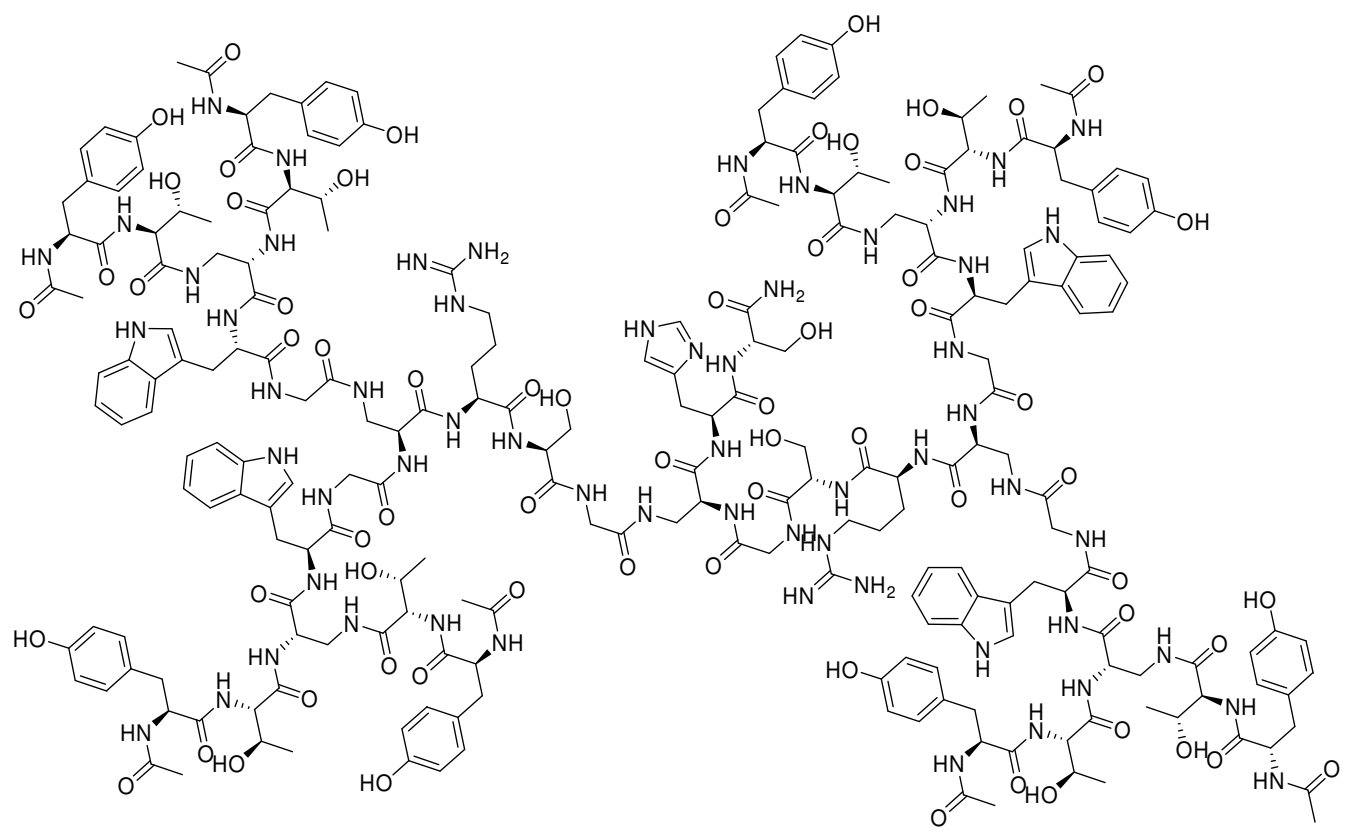

Starting with $250 \mathrm{mg}$ of NovaSyn ${ }^{\circledR}$ TGR resin $(0.26 \mathrm{mmol} / \mathrm{g})$, the dendrimer RM-G3 was obtained using procedure A as colorless foamy solid after cleavage from the resin and preparative RP-HPLC purification (24.8 mg, $7.3 \%)$.

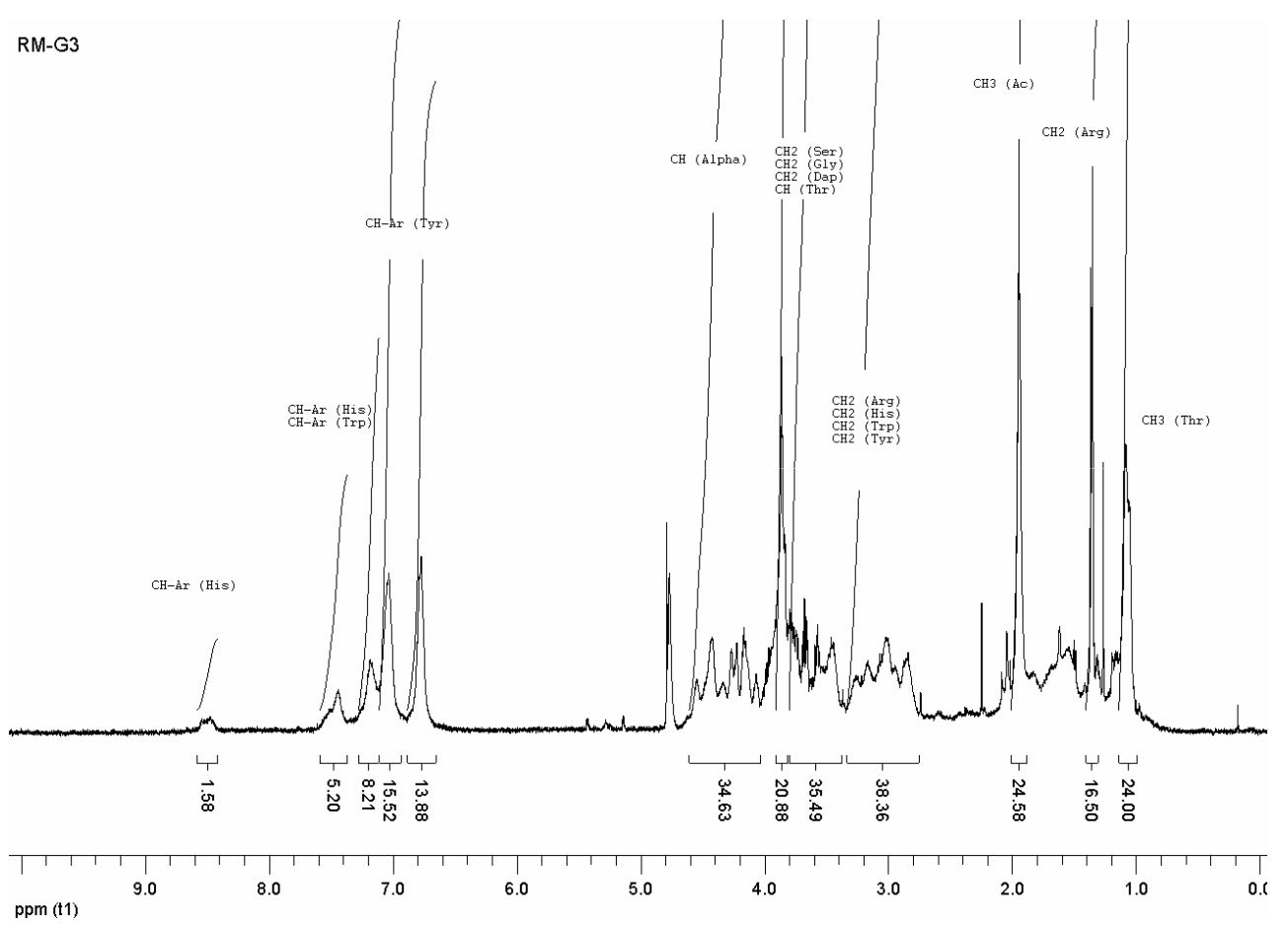


Preparative RP-HPLC: $t_{\mathrm{R}}=24 \min (\mathrm{A} / \mathrm{B}=70 / 30$ to $\mathrm{A} / \mathrm{B}=30 / 70$ in $40 \mathrm{~min})$

Analytical RP-HPLC: $t_{\mathrm{R}}=8.4 \mathrm{~min}(\mathrm{~A} / \mathrm{B}=70 / 30$ to $\mathrm{A} / \mathrm{B}=0 / 100$ in $15 \mathrm{~min})$

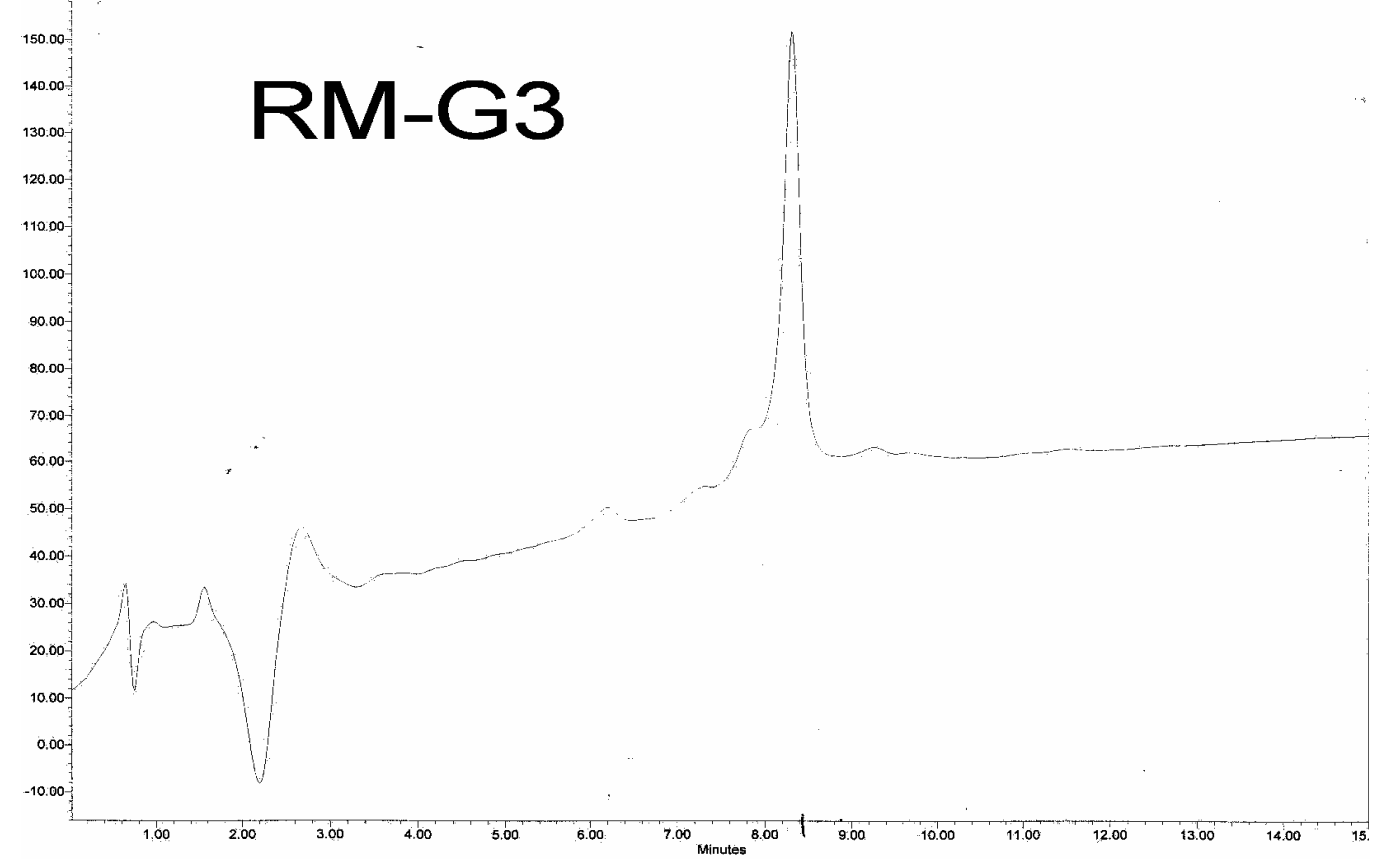

MS (ES+) calcd for $\mathrm{C}_{224} \mathrm{H}_{294} \mathrm{~N}_{59} \mathrm{O}_{66}[\mathrm{M}+\mathrm{H}]^{+}$: 4866.1, found: 4868.7; [M+Na] $]^{+}$: 4888.1, found: 4891.2; $[\mathrm{M}+\mathrm{K}]^{+}:$4904.2, found: 4908.2.

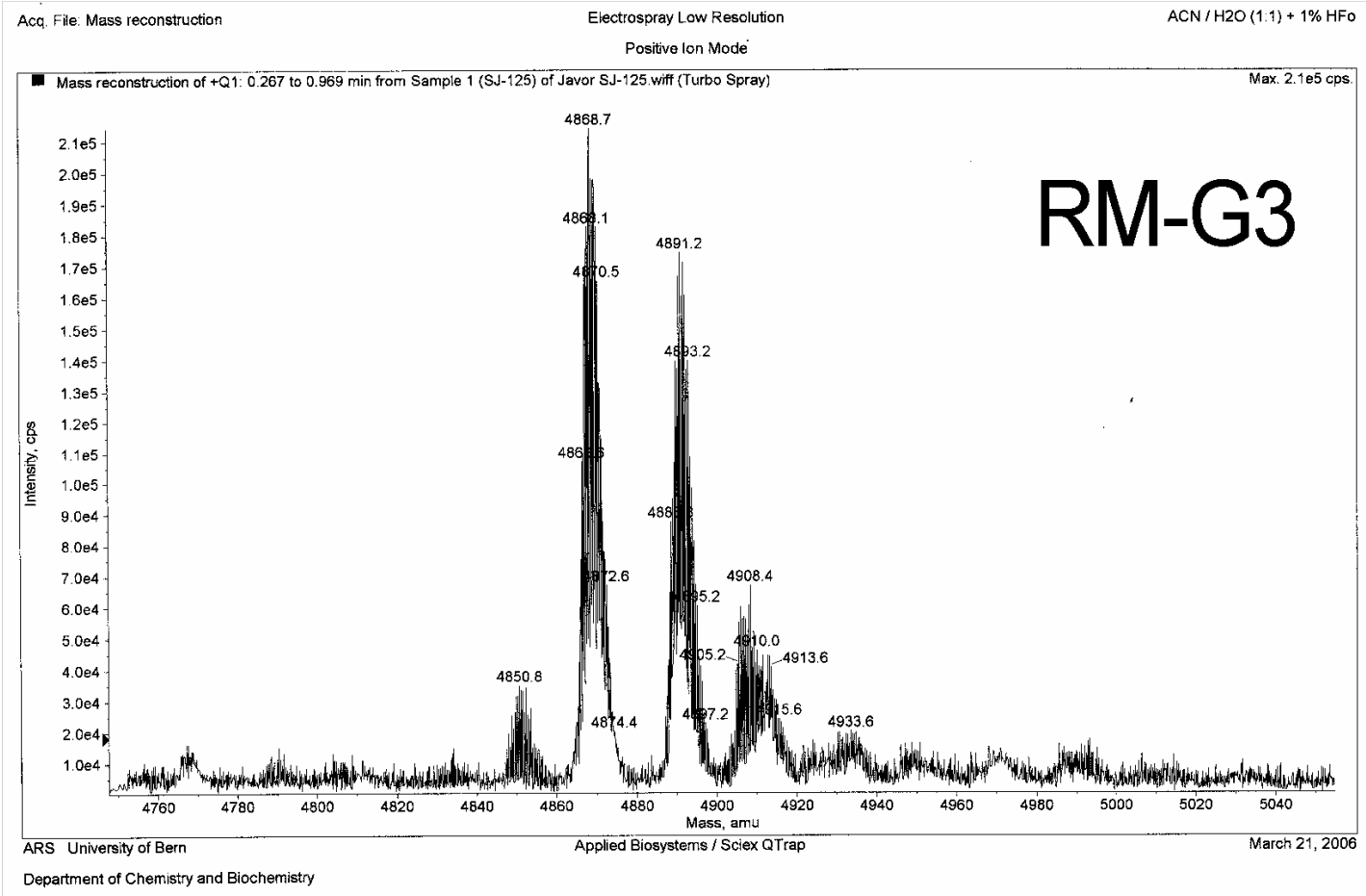


Michaelis-Menten plots for determination of $\boldsymbol{k}_{\text {cat }}$ and $\boldsymbol{K}_{\mathrm{M}}$
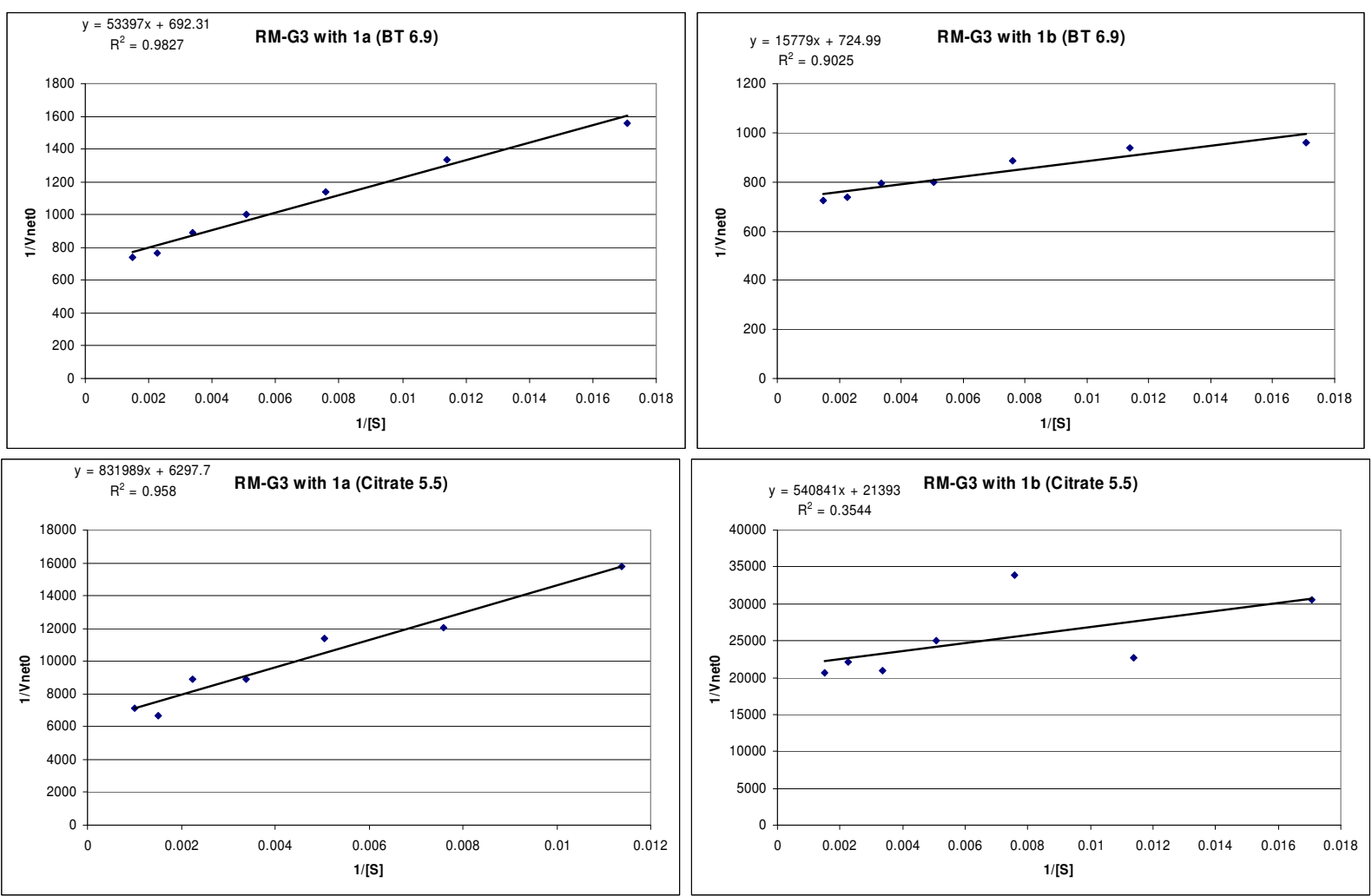


\section{Peptide H-G0: Ac-His-Ala-Ala-His-Leu-NH2}

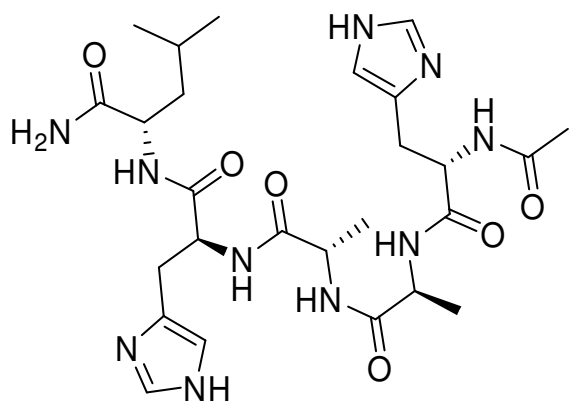

Starting with $250 \mathrm{mg}$ of Rink amide Novagel resin $(0.63 \mathrm{mmol} / \mathrm{g})$, the peptide H-G0 was obtained using procedure B as colorless solid after cleavage from the resin and preparative RPHPLC purification (78.8 mg, $61.4 \%)$.

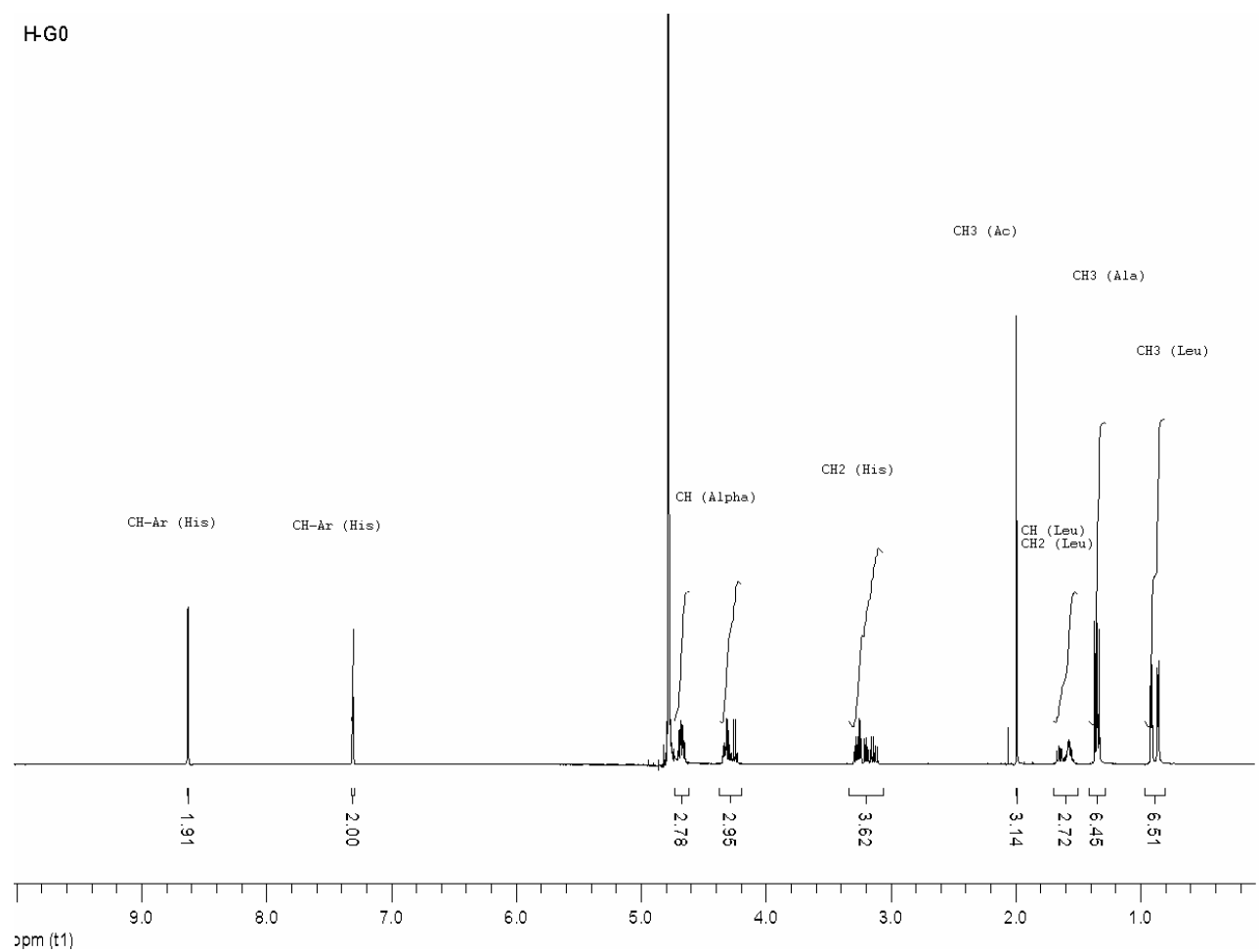


Preparative RP-HPLC: $t_{\mathrm{R}}=11 \min (\mathrm{A} / \mathrm{B}=90 / 10$ to $\mathrm{A} / \mathrm{B}=50 / 50$ in $40 \mathrm{~min})$

Analytical RP-HPLC: $t_{\mathrm{R}}=4.3 \min (\mathrm{A} / \mathrm{B}=100 / 0$ to $\mathrm{A} / \mathrm{B}=0 / 100$ in $10 \mathrm{~min})$

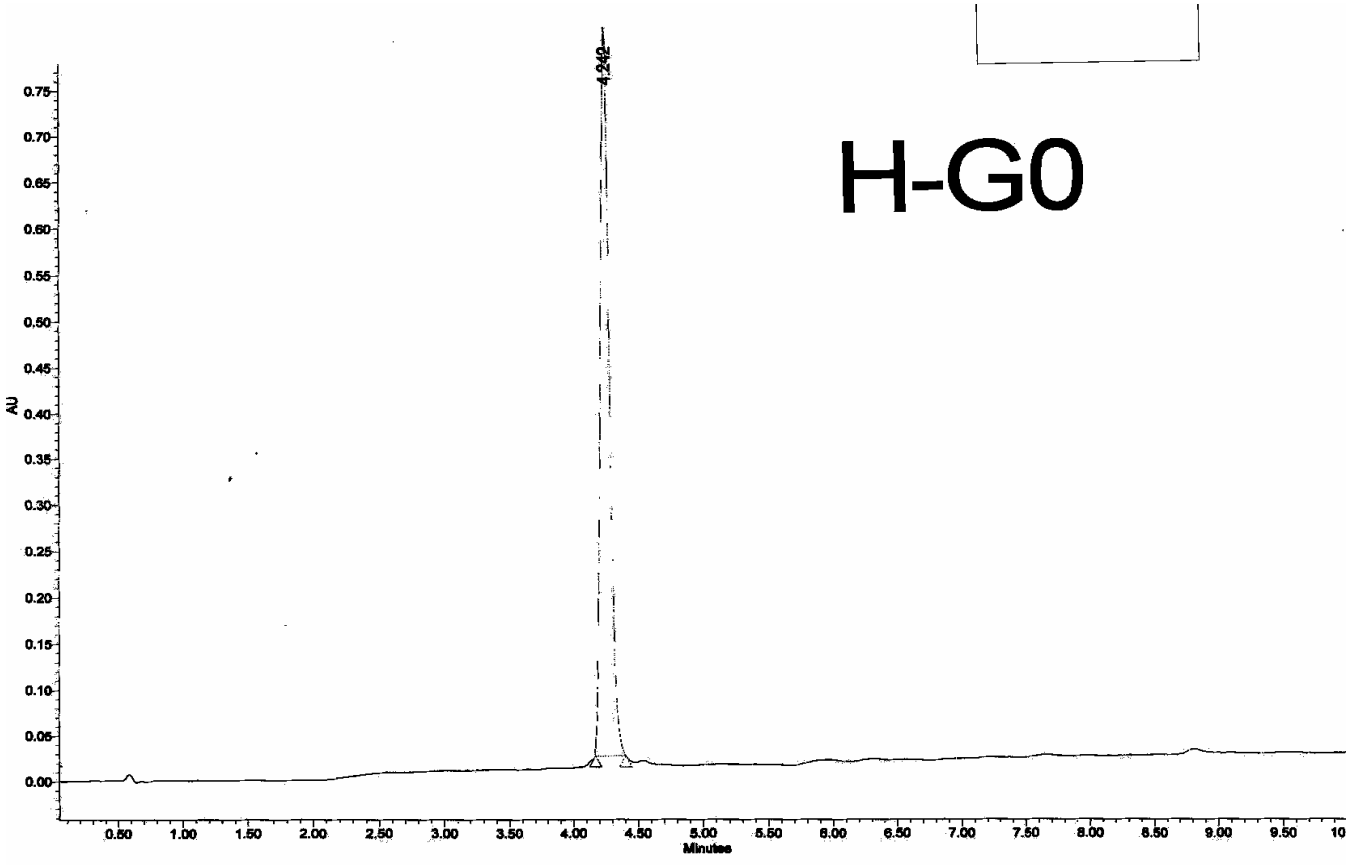

MS (ES+) calcd for $\mathrm{C}_{26} \mathrm{H}_{41} \mathrm{~N}_{10} \mathrm{O}_{6}[\mathrm{M}+\mathrm{H}]^{+}:$589.3, found: 589.4; [M+Na] $]^{+}$: 611.3, found: 611.4;

$[\mathrm{M}+2 \mathrm{H}]^{2+} / 2$ : 295.2, found: 295.4 .

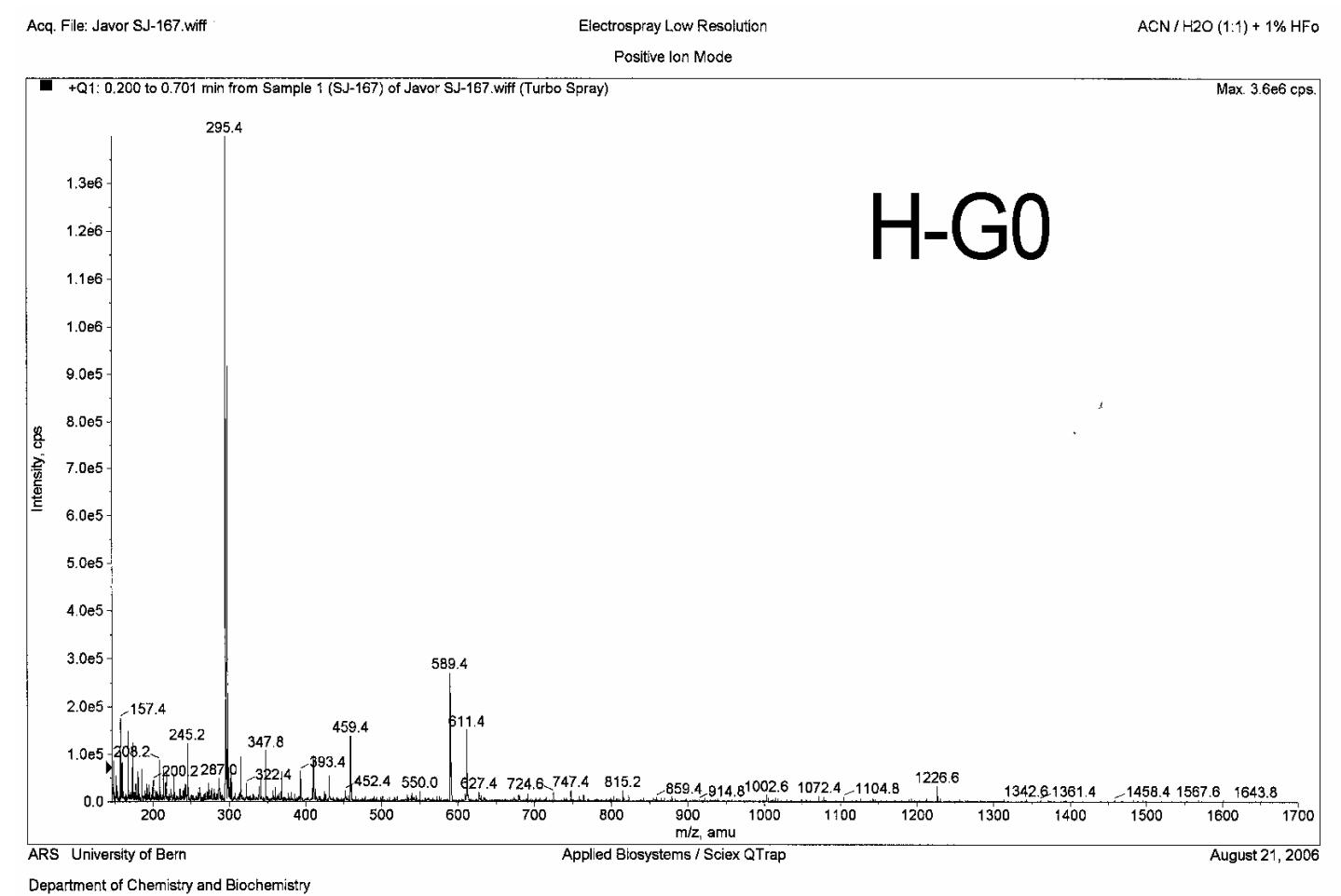


Michaelis-Menten plots for determination of $\boldsymbol{k}_{\text {cat }}$ and $\boldsymbol{K}_{\mathrm{M}}$
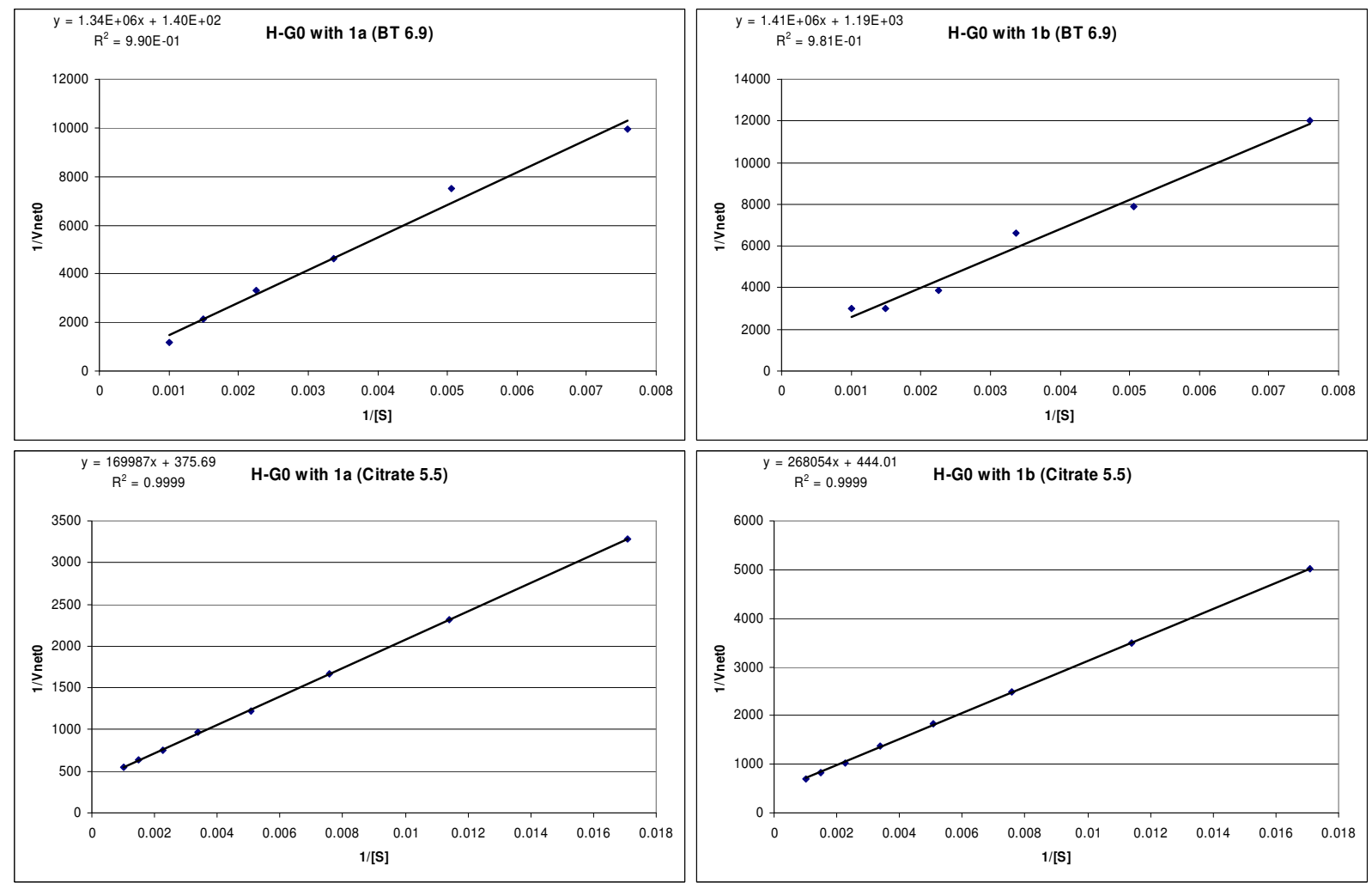


\section{Peptide H-G0’: Ac-His-Ala-Ala-His-NH2}

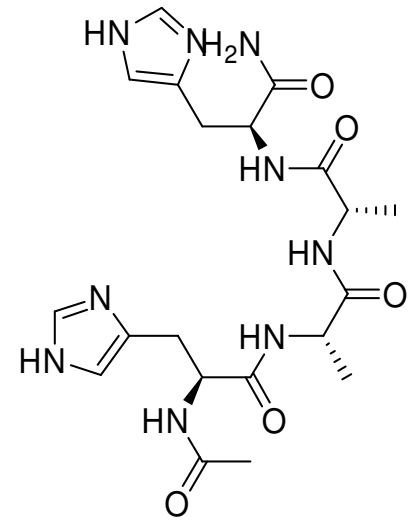

Starting with $250 \mathrm{mg}$ of Rink amide Novagel resin $(0.63 \mathrm{mmol} / \mathrm{g})$, the peptide H-G0' was obtained using procedure B as colorless solid after cleavage from the resin and preparative RPHPLC purification $(67.3 \mathrm{mg}, 60.9 \%)$.

$H G 0^{\prime}$

$$
\text { CH3 (AC) CH3 (Ala) }
$$
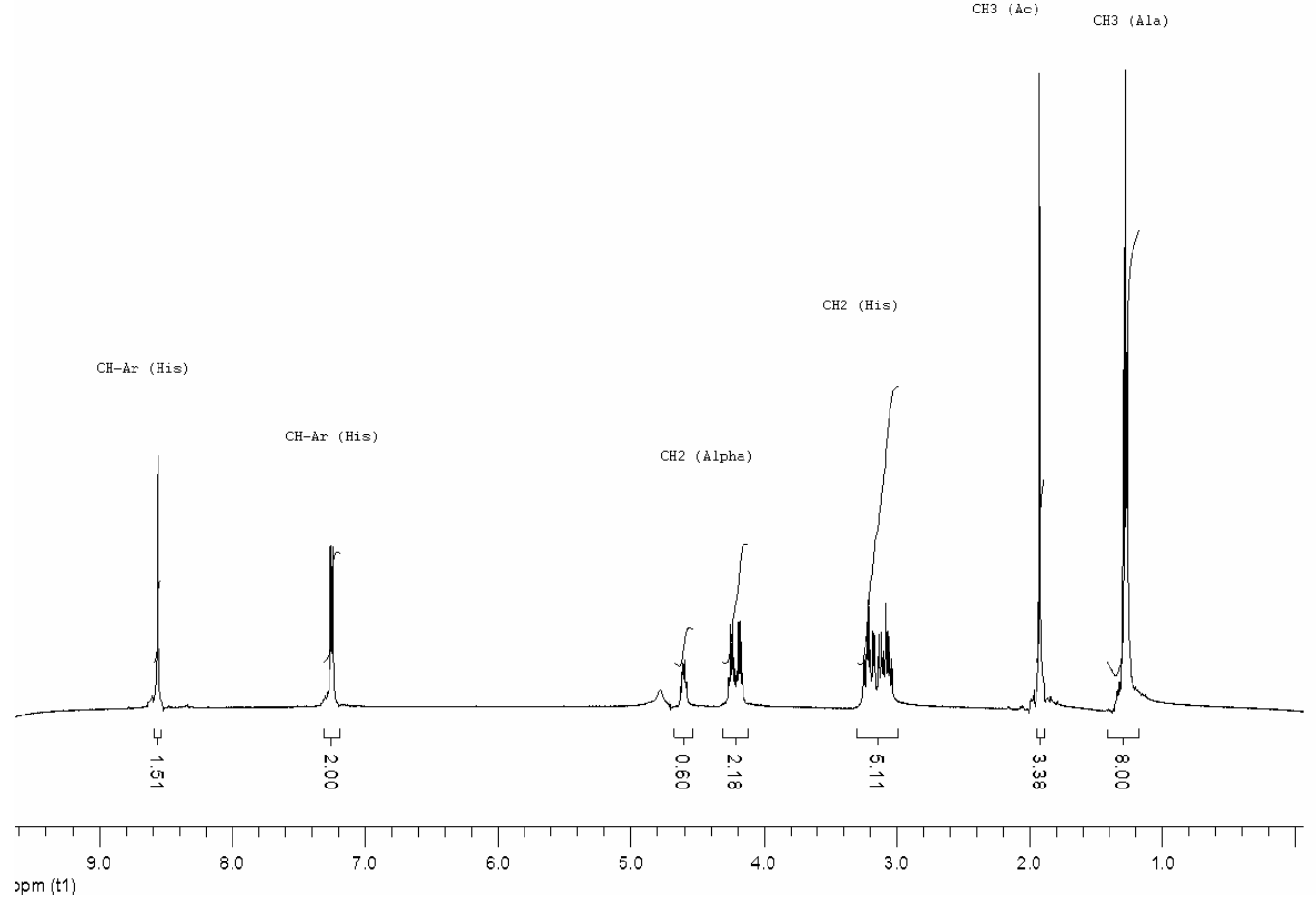
Preparative RP-HPLC: $t_{\mathrm{R}}=10 \mathrm{~min}(\mathrm{~A} / \mathrm{B}=100 / 0$ to $\mathrm{A} / \mathrm{B}=70 / 30$ in $30 \mathrm{~min})$

Analytical RP-HPLC: $t_{\mathrm{R}}=2.5 \mathrm{~min}(\mathrm{~A} / \mathrm{B}=100 / 0$ to $\mathrm{A} / \mathrm{B}=0 / 100$ in $10 \mathrm{~min})$

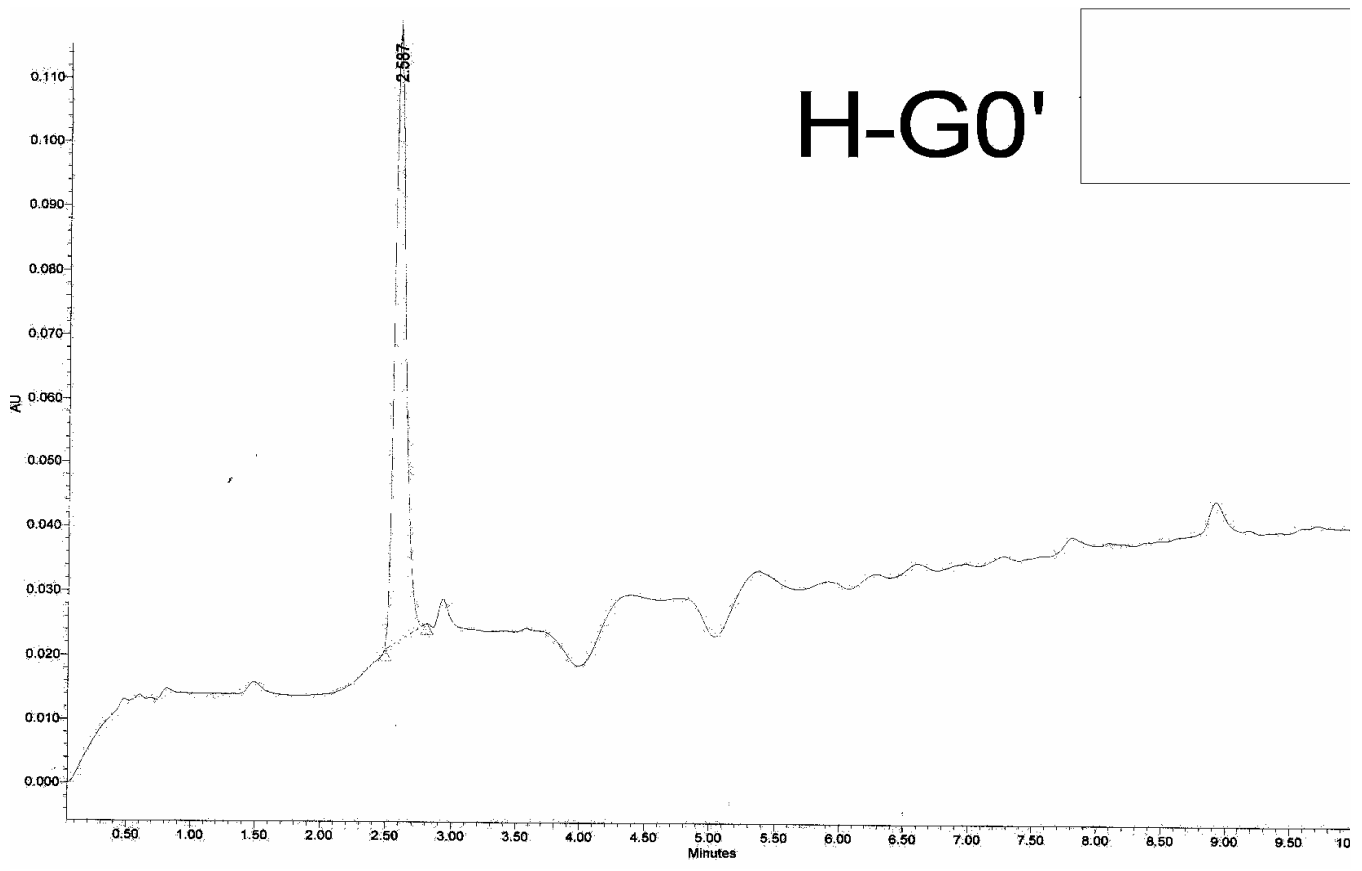

MS (ES+) calcd for $\mathrm{C}_{20} \mathrm{H}_{30} \mathrm{~N}_{9} \mathrm{O}_{5}[\mathrm{M}+\mathrm{H}]^{+}:$476.2, found: 476.4; [M+Na] $]^{+}$: 498.2, found: 498.4; $[\mathrm{M}+2 \mathrm{H}]^{2+} / 2: 238.6$, found: 238.8 .

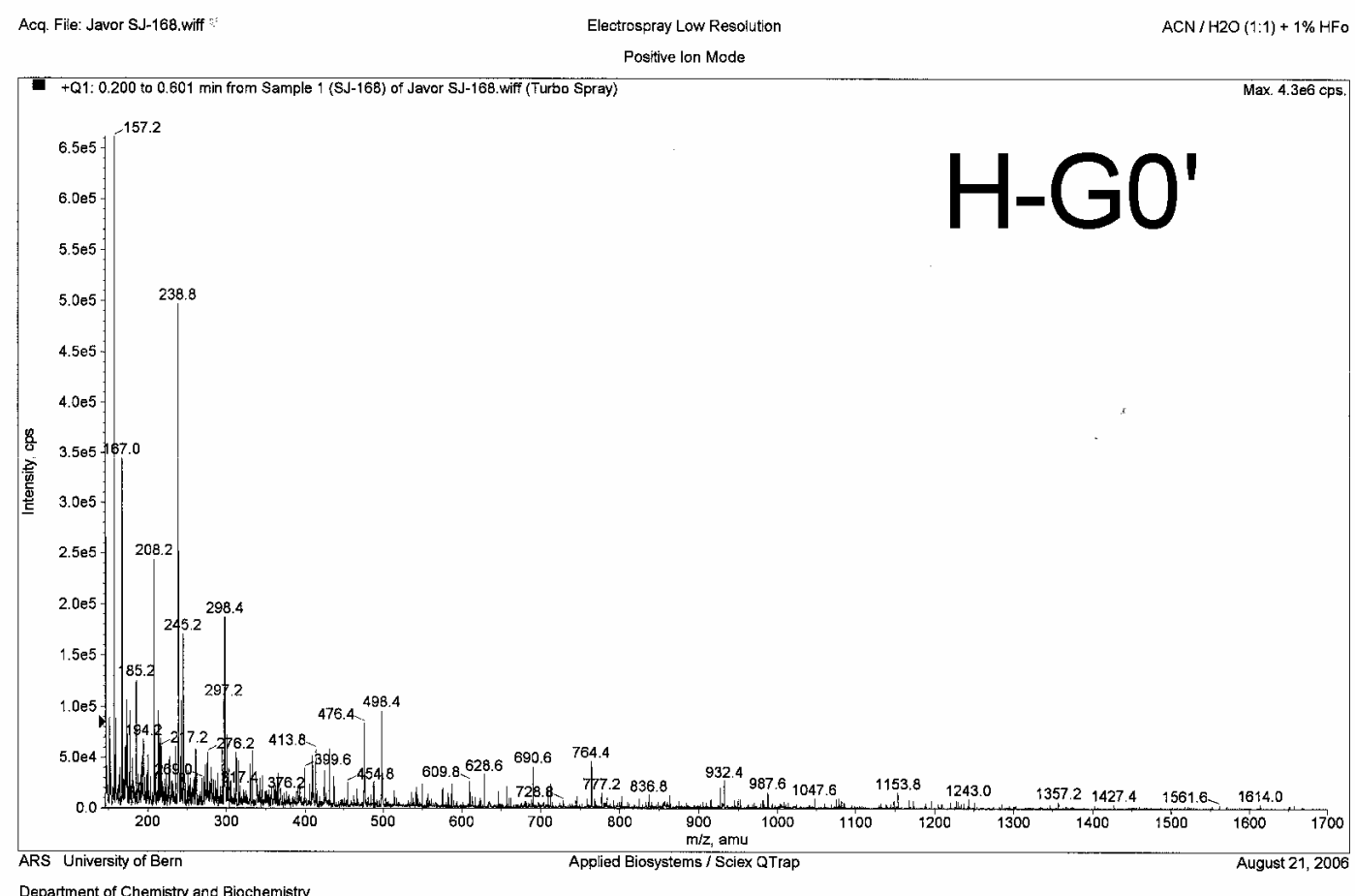


Michaelis-Menten plots for determination of $\boldsymbol{k}_{\text {cat }}$ and $\boldsymbol{K}_{\mathrm{M}}$
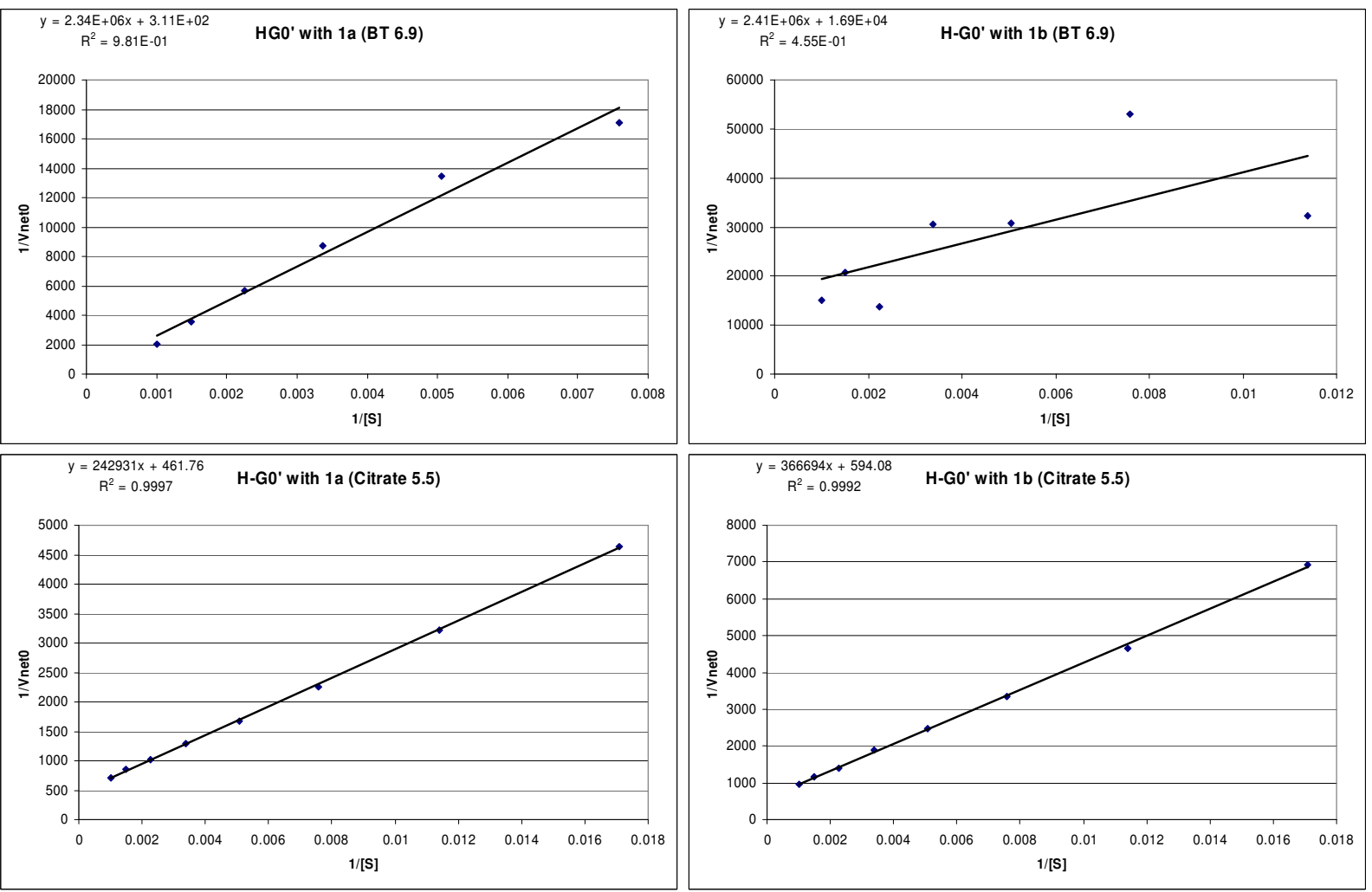


\section{Dendrimer H-G1: (Ac-His-Ala) ${ }_{2}$ Dap-His-Leu-NH 2}

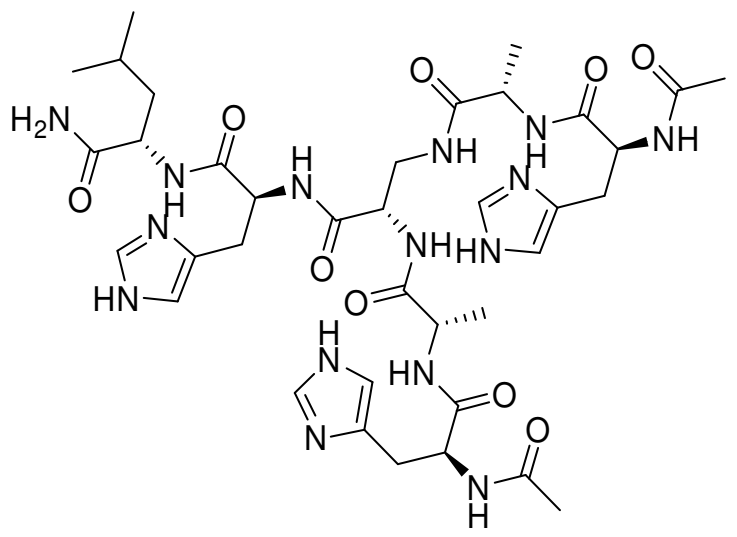

Starting with $250 \mathrm{mg}$ of NovaSyn ${ }^{\circledR}$ TGR resin $(0.23 \mathrm{mmol} / \mathrm{g})$, the dendrimer H-G1 was obtained using procedure A as colorless foamy solid after cleavage from the resin and preparative RPHPLC purification (40.4 mg, $58.7 \%$ ).

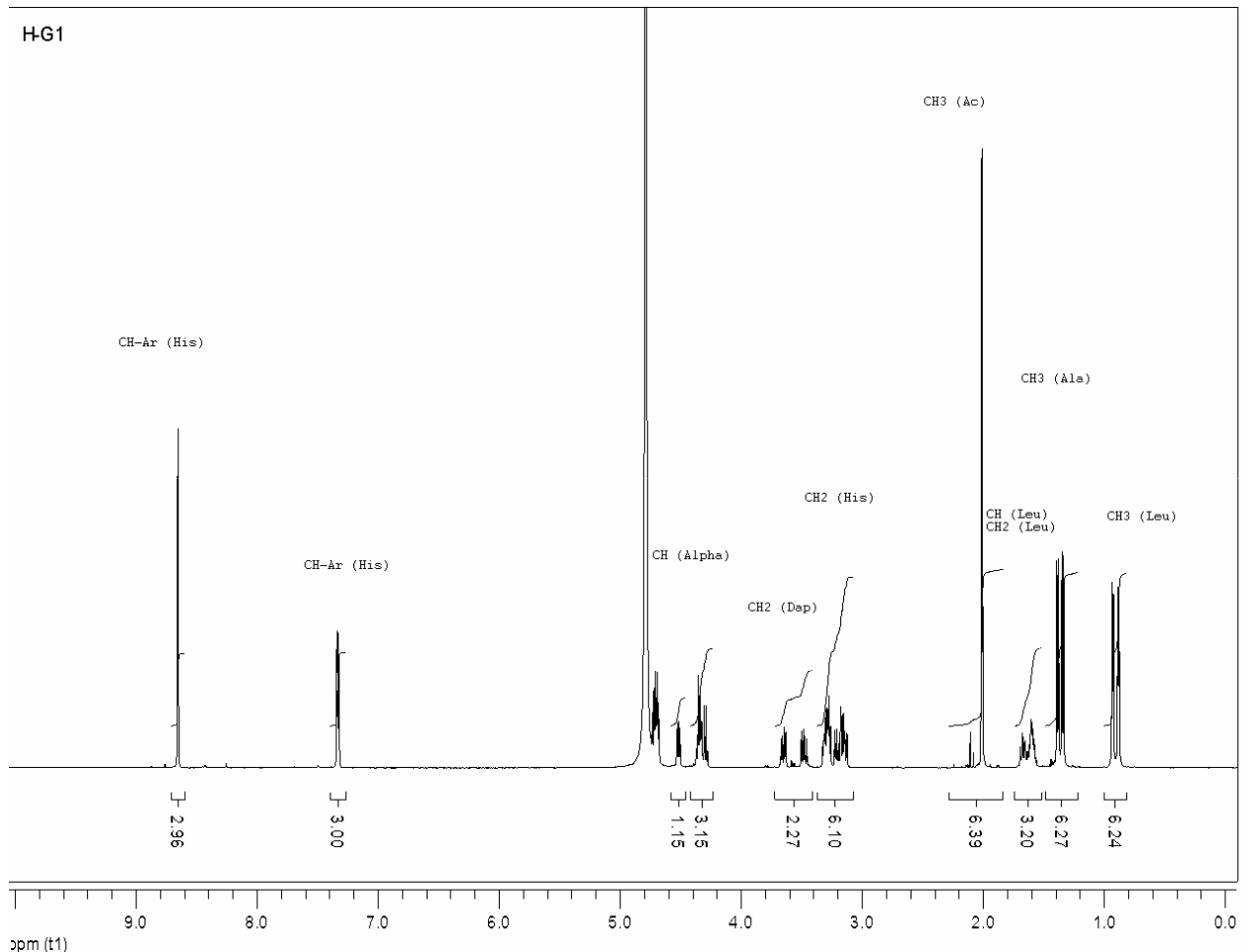


Preparative RP-HPLC: $t_{\mathrm{R}}=11 \mathrm{~min}(\mathrm{~A} / \mathrm{B}=95 / 5$ to $\mathrm{A} / \mathrm{B}=65 / 35$ in $30 \mathrm{~min})$

Analytical RP-HPLC: $t_{\mathrm{R}}=6.2 \min (\mathrm{A} / \mathrm{B}=100 / 0$ to $\mathrm{A} / \mathrm{B}=60 / 40$ in $8 \mathrm{~min})$

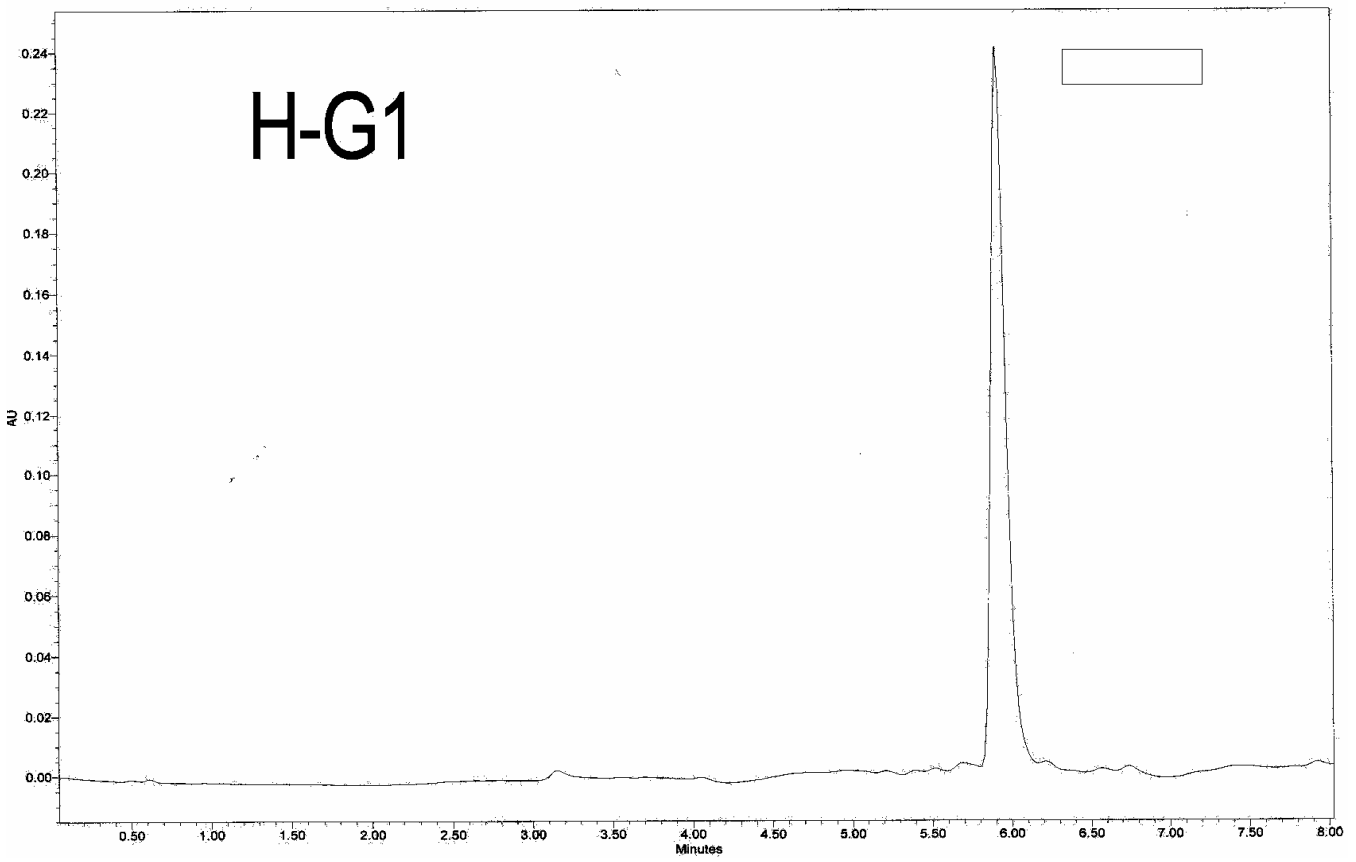

MS (ES+) calcd for $\mathrm{C}_{37} \mathrm{H}_{56} \mathrm{~N}_{15} \mathrm{O}_{9}[\mathrm{M}+\mathrm{H}]^{+}$: 854.4, found: 854.6; [M+Na] $]^{+}$: 876.4, found: 876.4;

$[\mathrm{M}+2 \mathrm{H}]^{2+} / 2: 427.7$, found: $428.0 ;[\mathrm{M}+3 \mathrm{H}]^{3+} / 3: 285.5$, found: 285.8 .

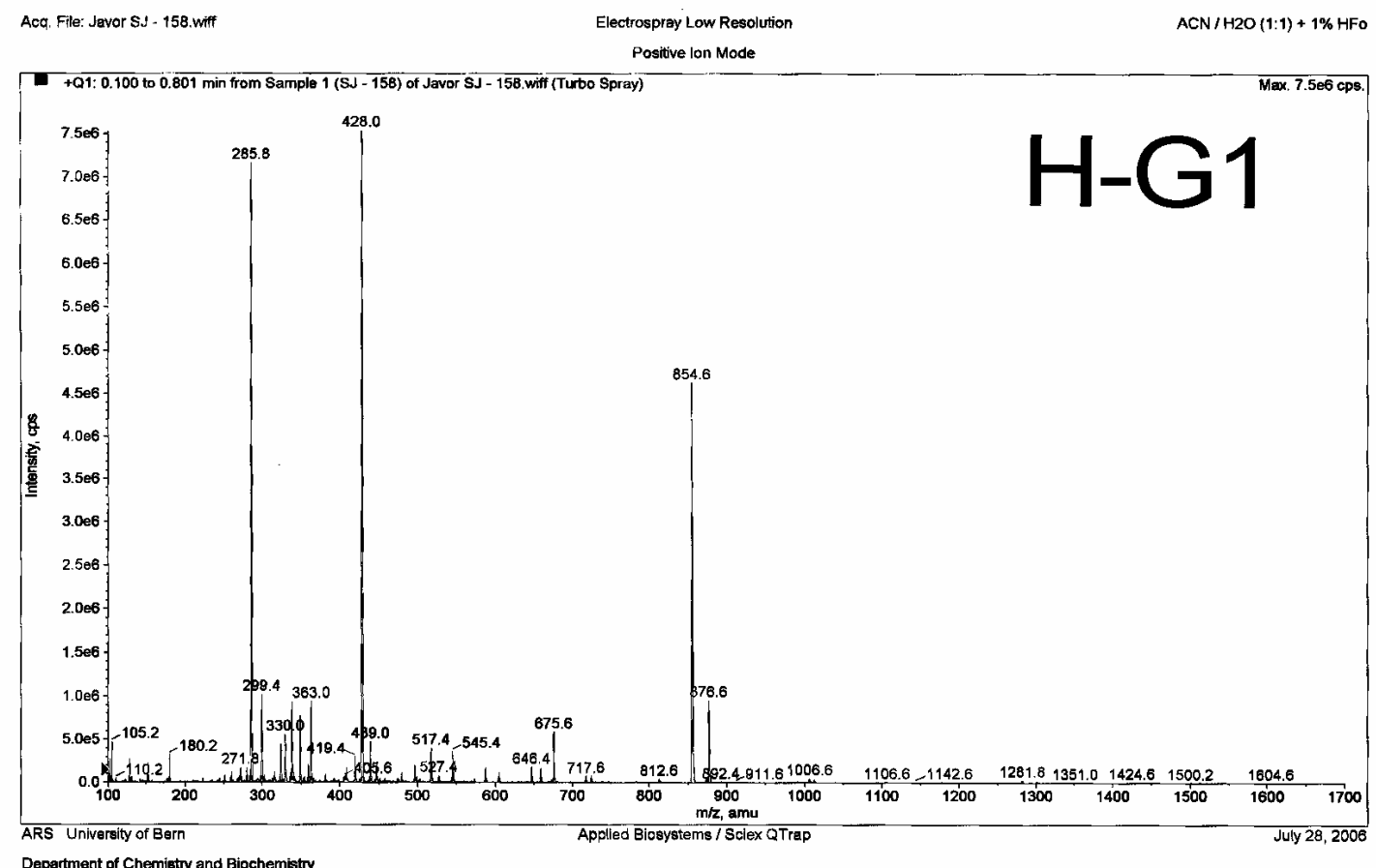


Michaelis-Menten plots for determination of $\boldsymbol{k}_{c a t}$ and $\boldsymbol{K}_{M}$
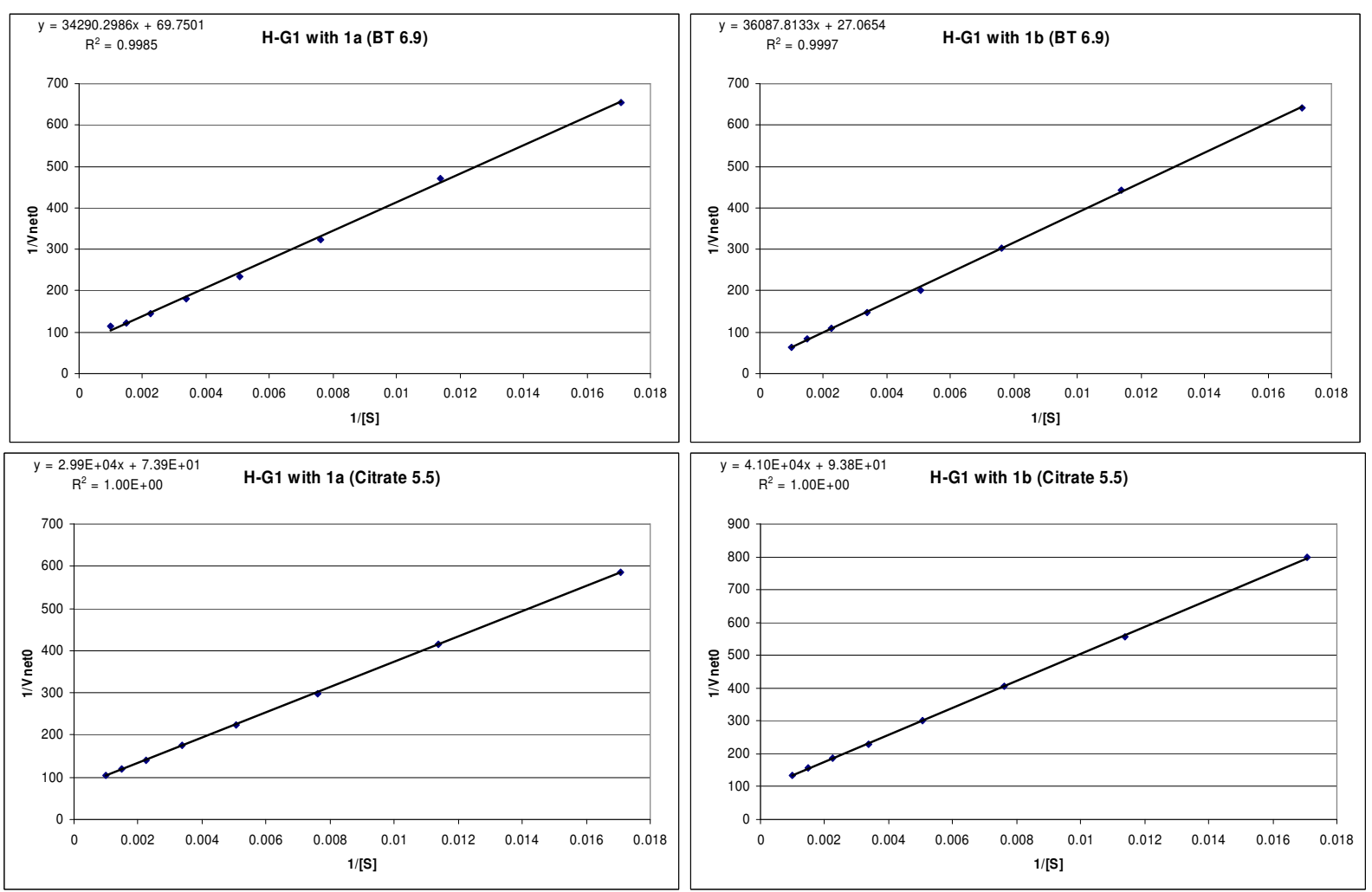


\section{Dendrimer H-G1': (Ac-His-Ala) ${ }_{2}$ Dap-Ala-Leu-NH ${ }_{2}$}

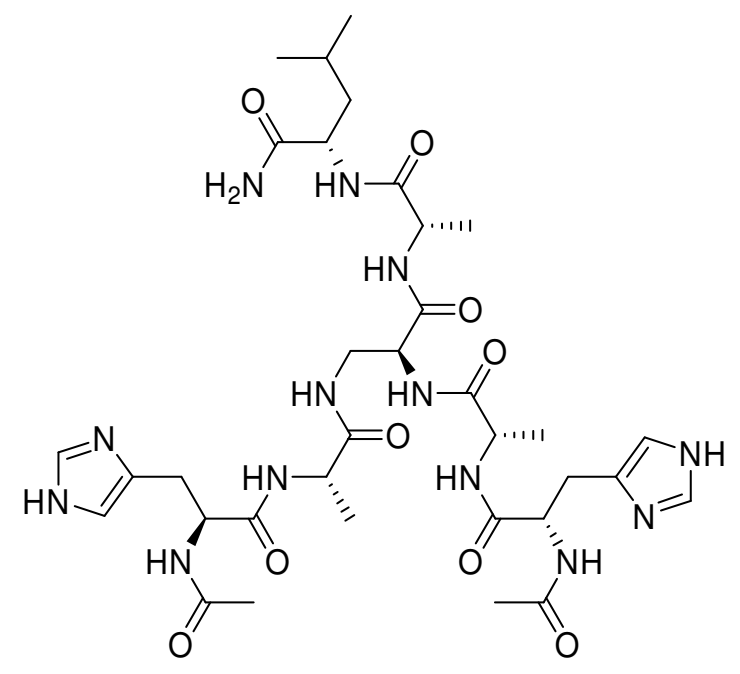

Starting with $250 \mathrm{mg}$ of Rink amide Novagel resin $(0.63 \mathrm{mmol} / \mathrm{g})$, the dendrimer H-G1' was obtained using procedure B as colorless solid after cleavage from the resin and preparative RPHPLC purification $(73.3 \mathrm{mg}, 45.9 \%)$.

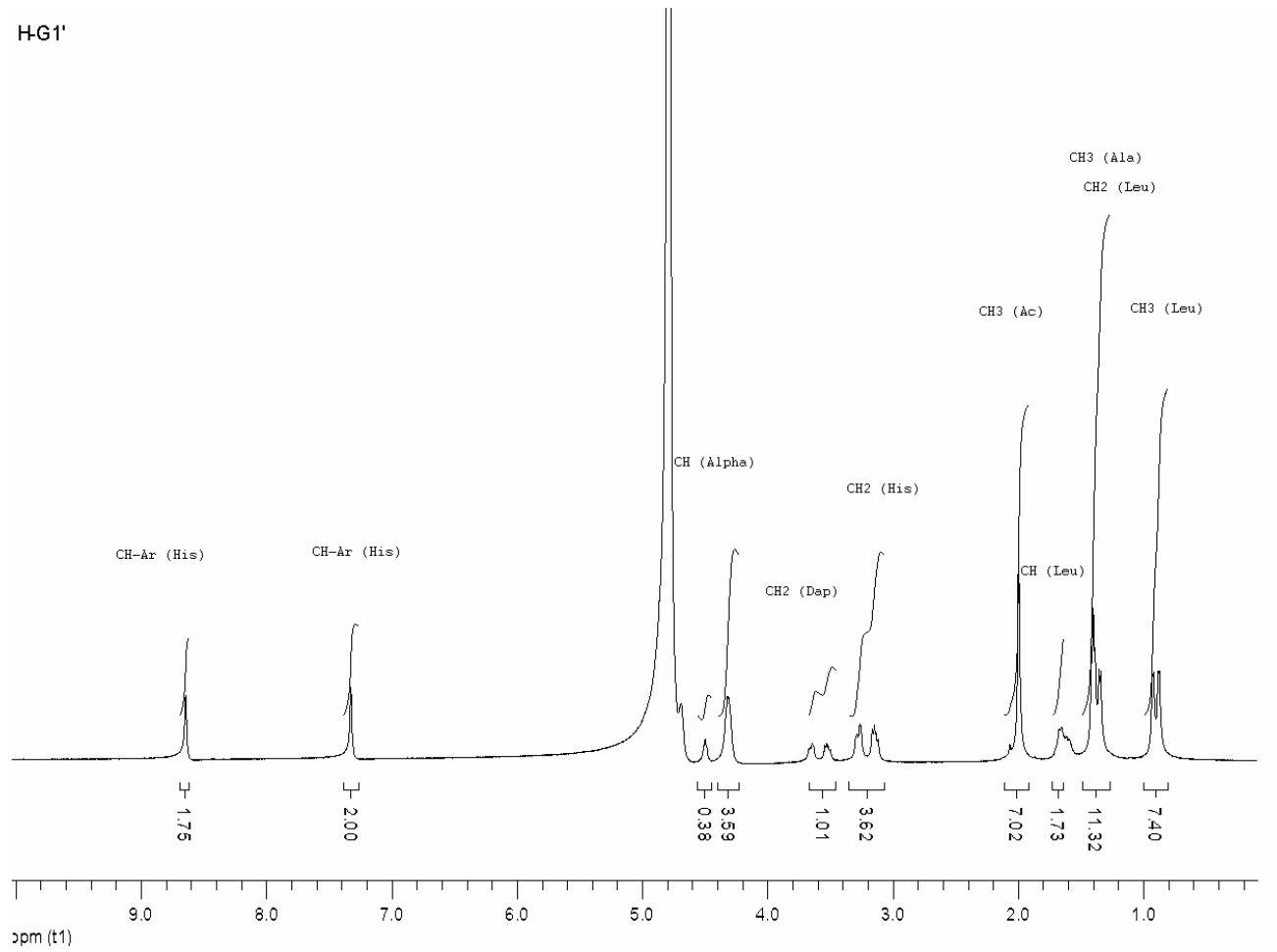


Preparative RP-HPLC: $t_{\mathrm{R}}=12 \min (\mathrm{A} / \mathrm{B}=90 / 10$ to $\mathrm{A} / \mathrm{B}=50 / 50$ in $40 \mathrm{~min})$ Analytical RP-HPLC: $t_{\mathrm{R}}=4.4 \min (\mathrm{A} / \mathrm{B}=100 / 0$ to $\mathrm{A} / \mathrm{B}=0 / 100$ in $10 \mathrm{~min})$

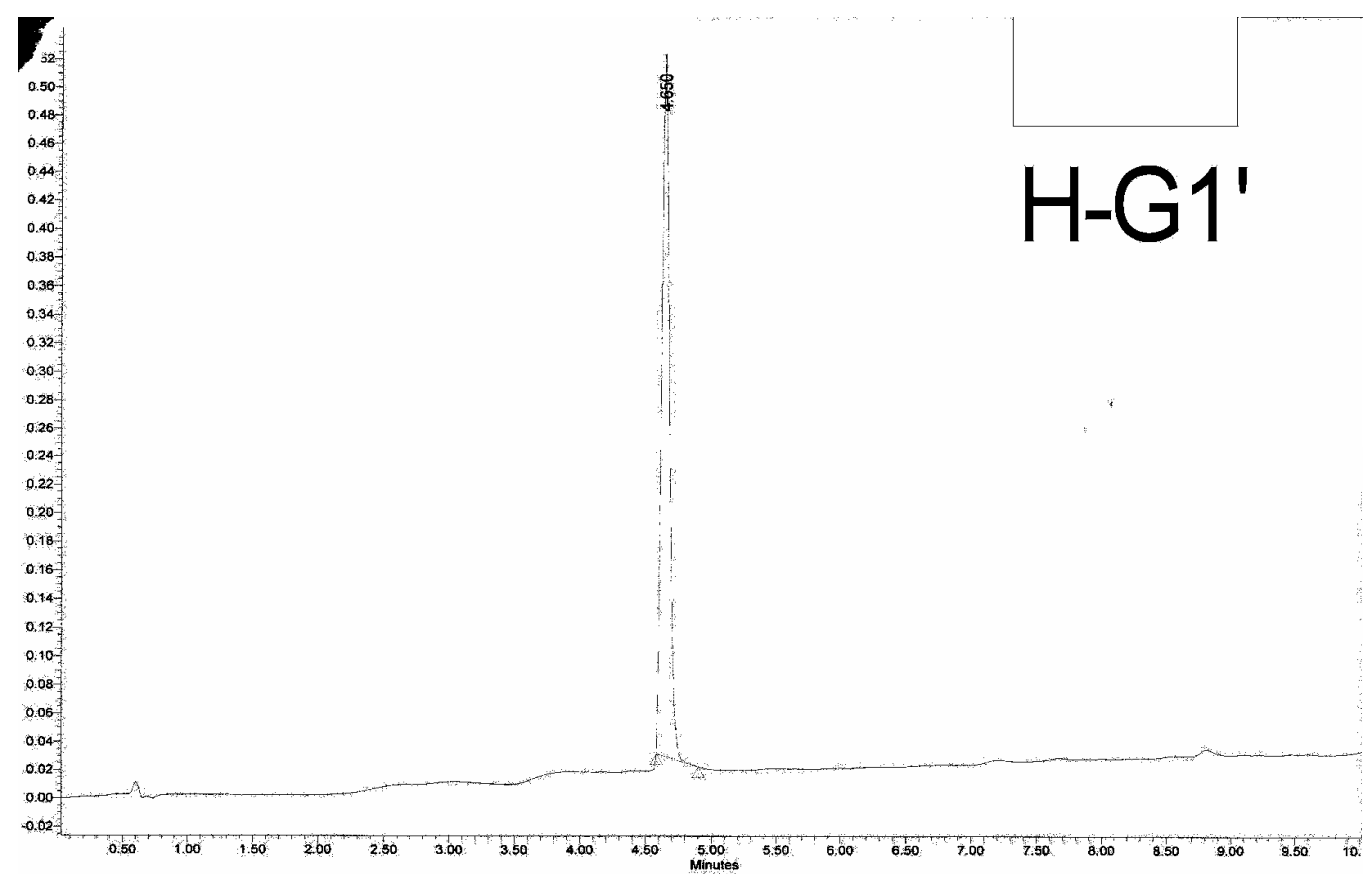

MS (ES+) calcd for $\mathrm{C}_{34} \mathrm{H}_{53} \mathrm{~N}_{13} \mathrm{O}_{9}[\mathrm{M}+\mathrm{H}]^{+}$: 788.4, found: 788.6; [M+H] $]^{+}$: 810.4, found: 810.6;

$[\mathrm{M}+2 \mathrm{H}]^{2+} / 2$ : 394.7, found: 395.0.

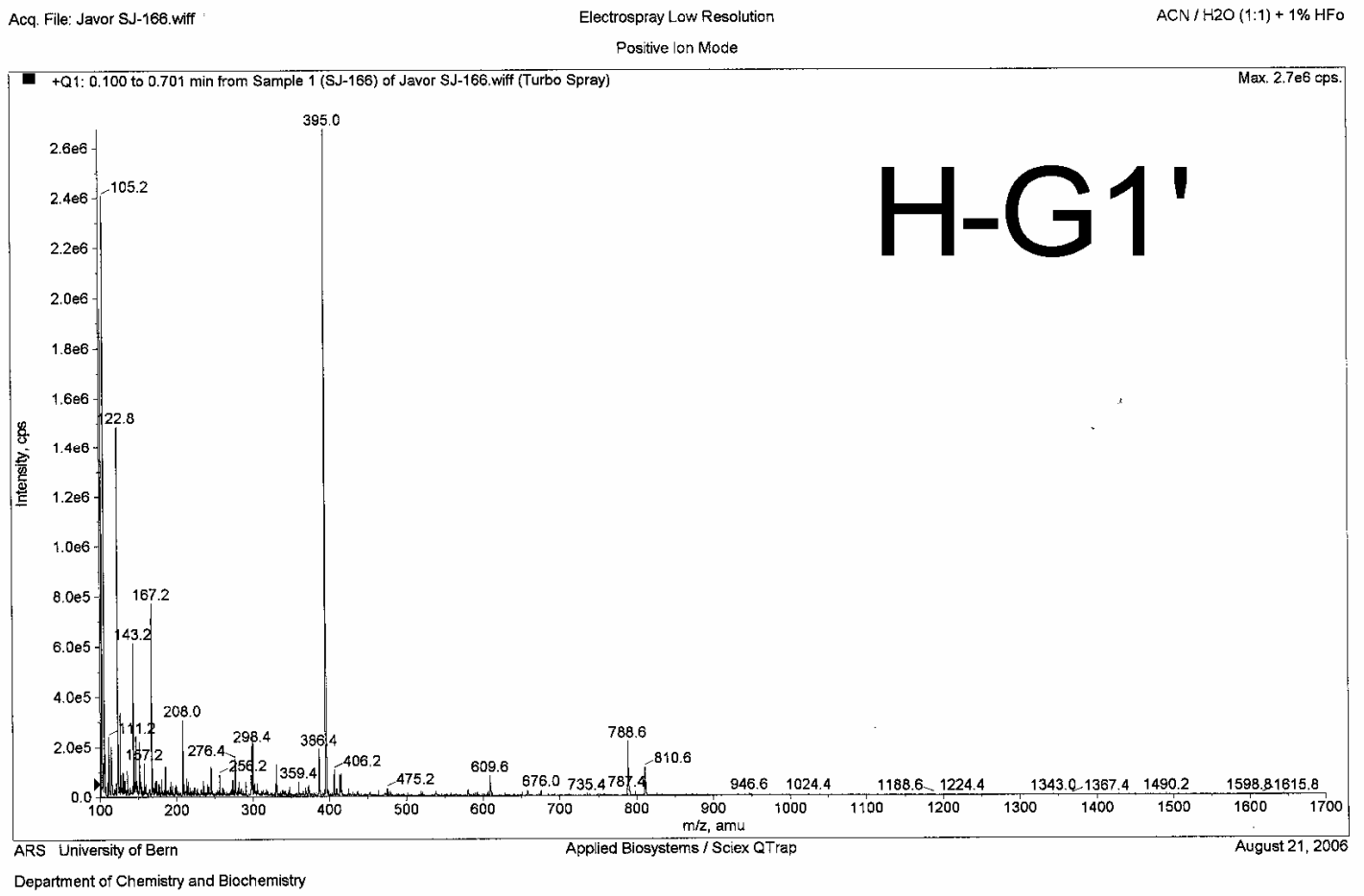


Michaelis-Menten plots for determination of $\boldsymbol{k}_{\text {cat }}$ and $\boldsymbol{K}_{\mathbf{M}}$
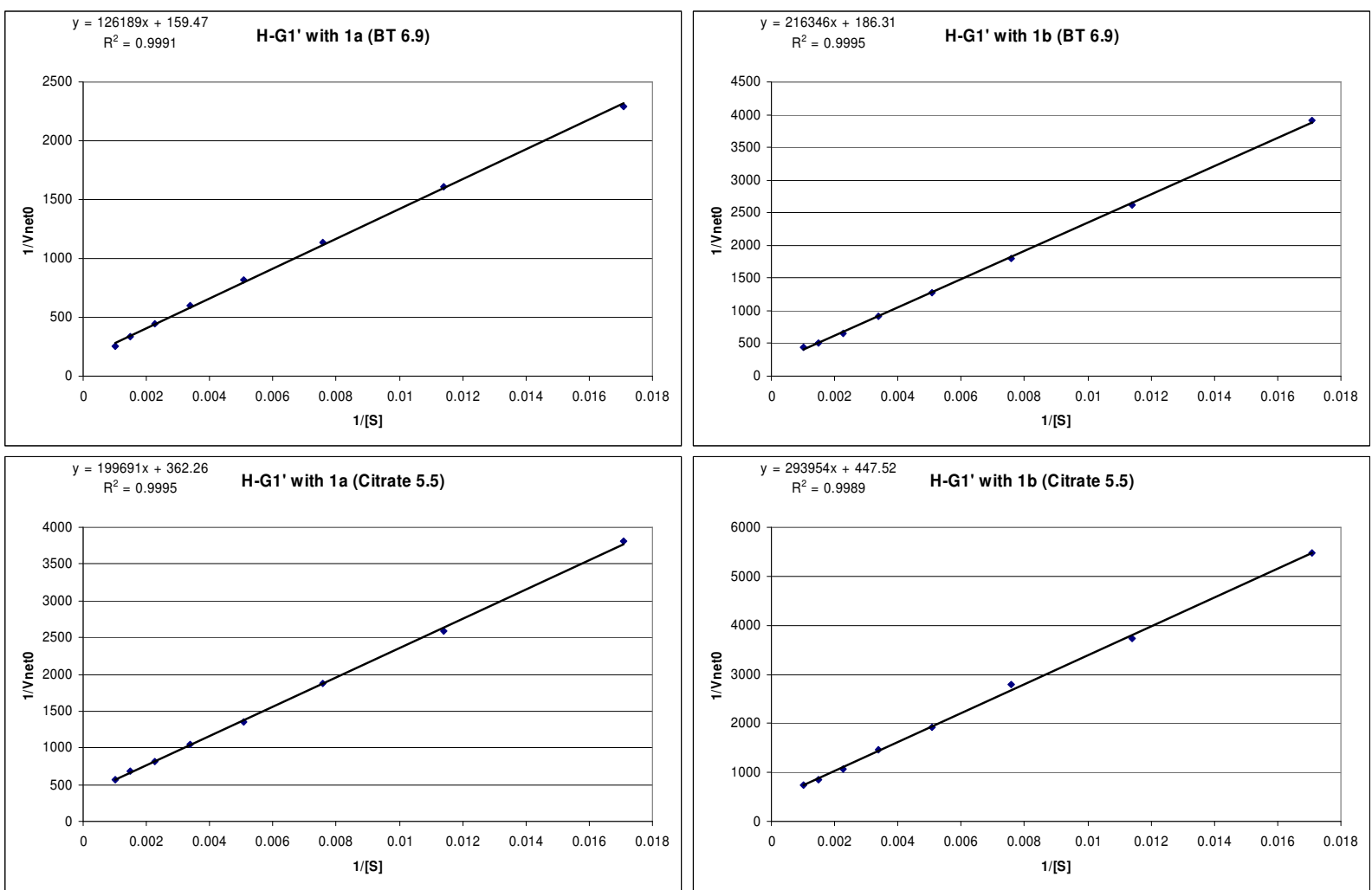


\section{Dendrimer H-G2: ((Ac-Ile-Thr $)_{2}$ Dap-His-Ala $)_{2}$ Dap-His-Leu-NH ${ }_{2}$}

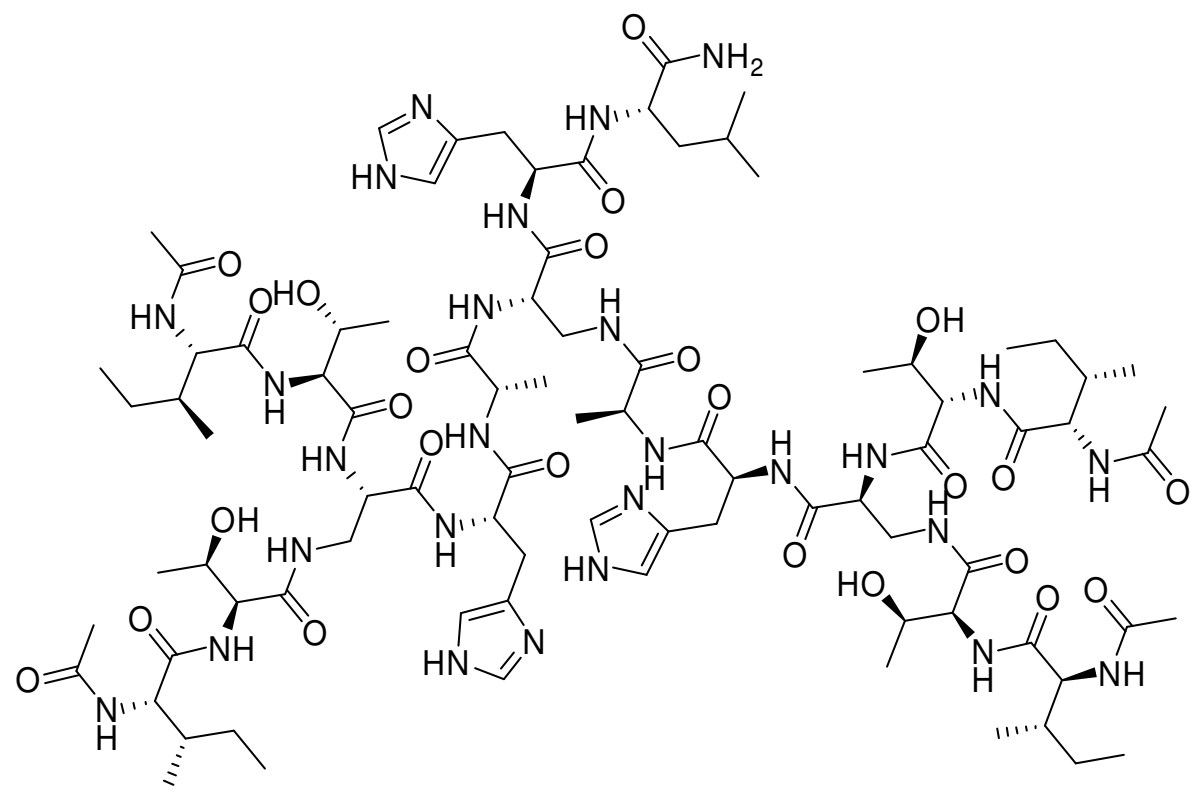

Starting with $250 \mathrm{mg}$ of NovaSyn ${ }^{\circledR}$ TGR resin $(0.23 \mathrm{mmol} / \mathrm{g})$, the dendrimer H-G2 was obtained using procedure A as colorless foamy solid after cleavage from the resin and preparative RPHPLC purification (10.2 mg, $7.7 \%)$.

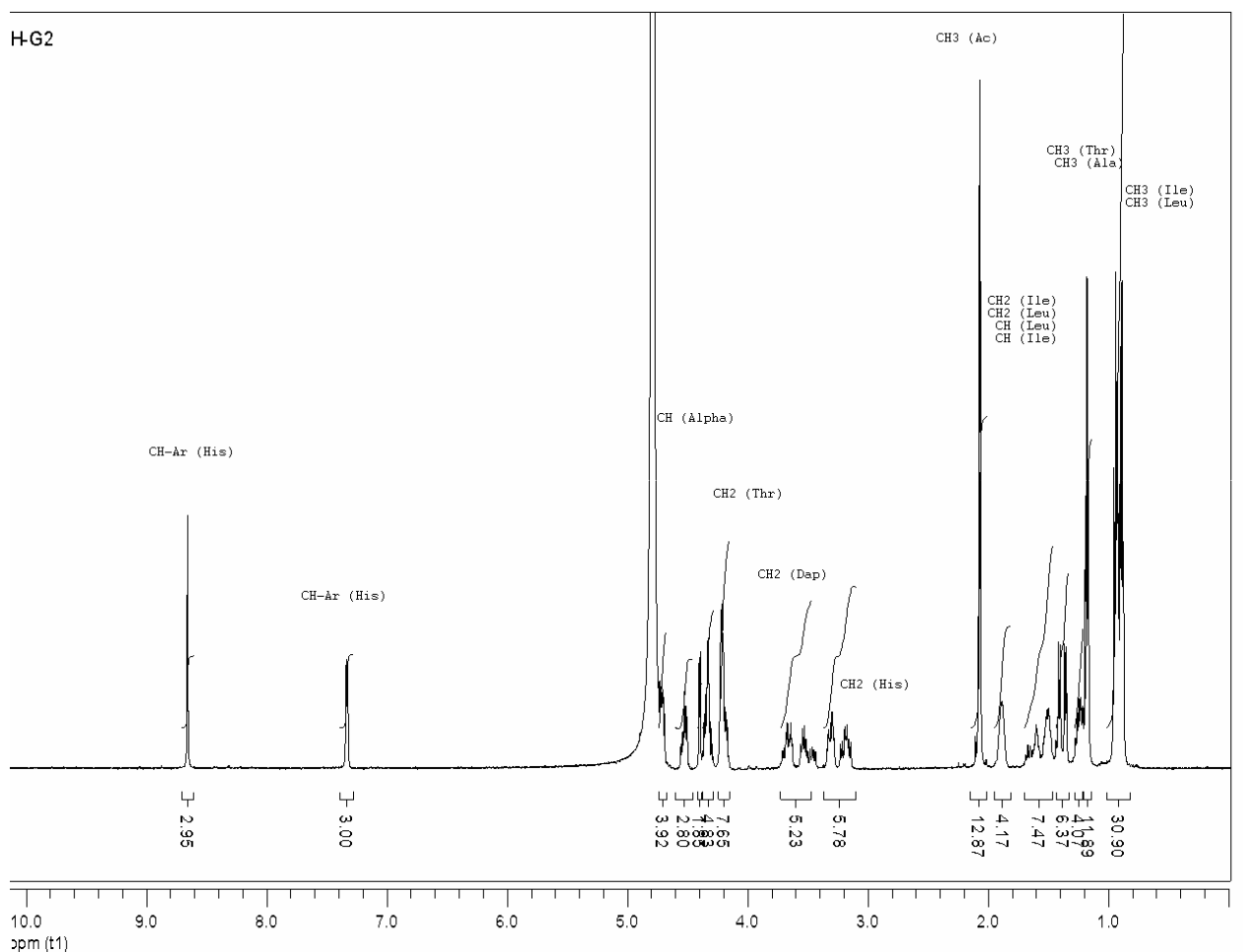


Preparative RP-HPLC: $t_{\mathrm{R}}=15 \min (\mathrm{A} / \mathrm{B}=70 / 30$ to $\mathrm{A} / \mathrm{B}=30 / 70$ in $40 \mathrm{~min})$ Analytical RP-HPLC: $t_{\mathrm{R}}=6.1 \mathrm{~min}(\mathrm{~A} / \mathrm{B}=70 / 30$ to $\mathrm{A} / \mathrm{B}=35 / 65$ in $7.5 \mathrm{~min})$

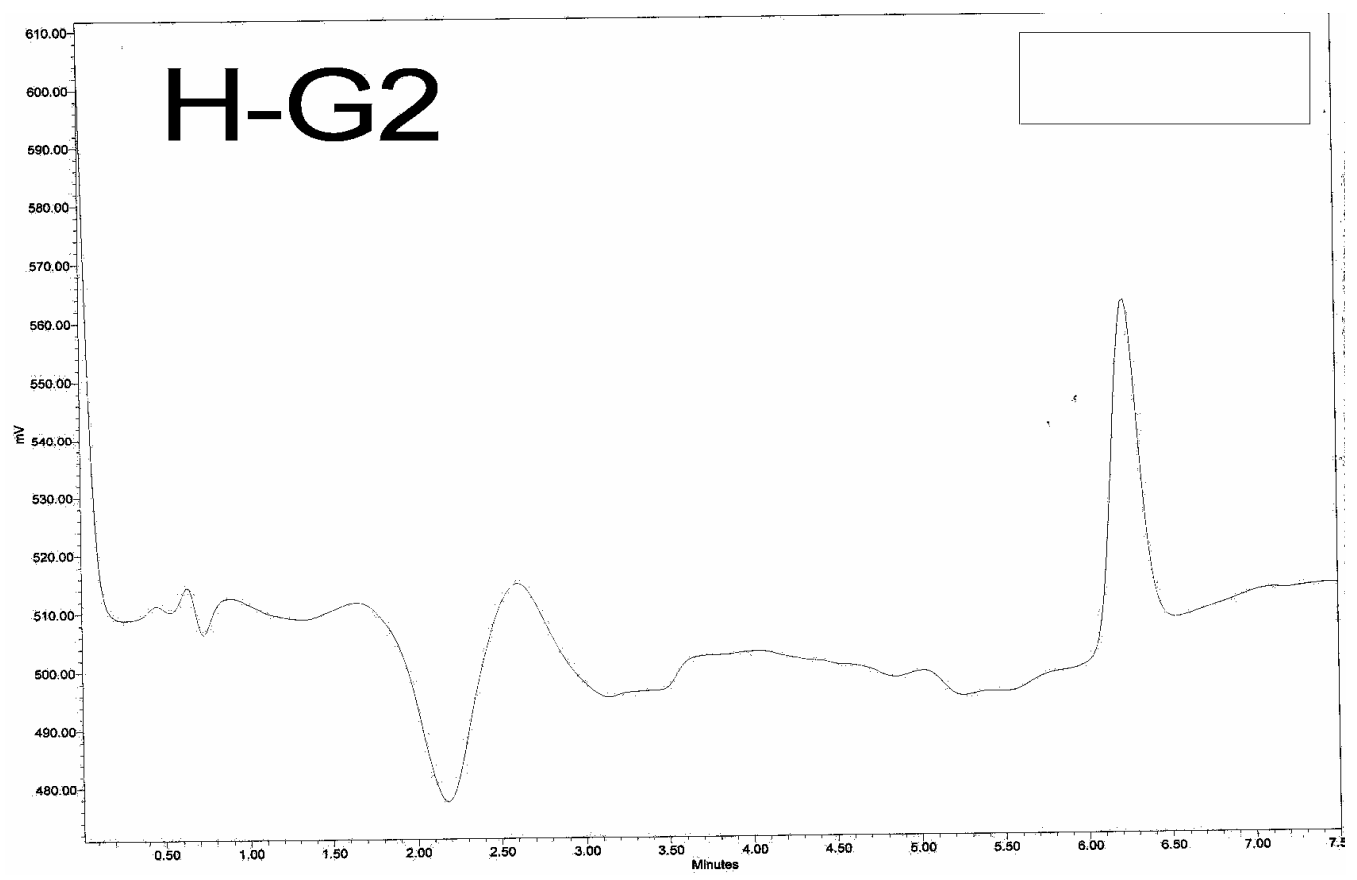

MS (ES+) calcd for $\mathrm{C}_{87} \mathrm{H}_{144} \mathrm{~N}_{27} \mathrm{O}_{25}[\mathrm{M}+\mathrm{H}]^{+}:$1967.1, found: 1967.4; [M+Na $]^{+}:$1989.1, found: 1989.0; [M+TFA] $]^{+}: 2080.1$, found: 2081.4 .

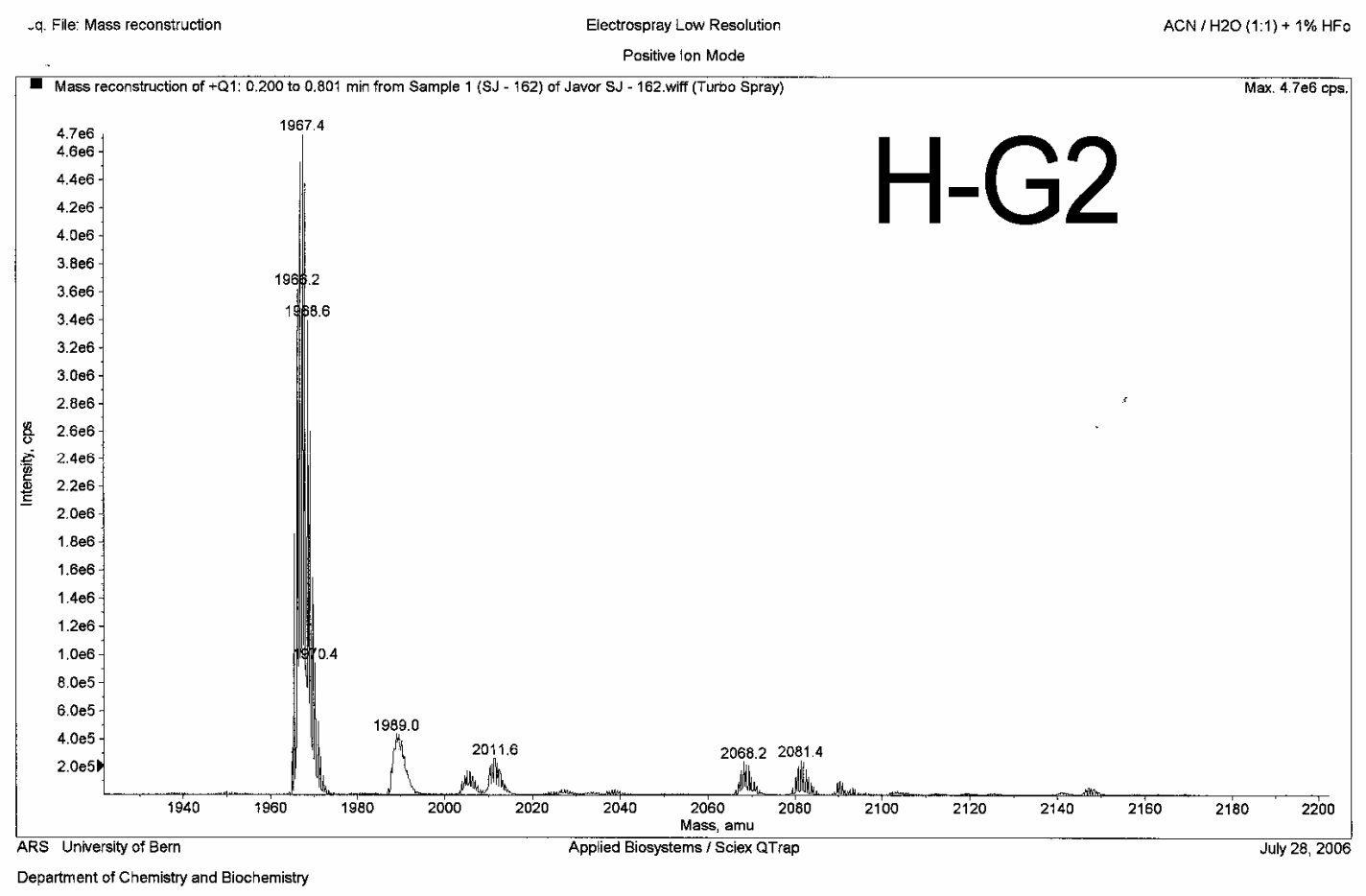


Michaelis-Menten plots for determination of $\boldsymbol{k}_{c a t}$ and $\boldsymbol{K}_{M}$
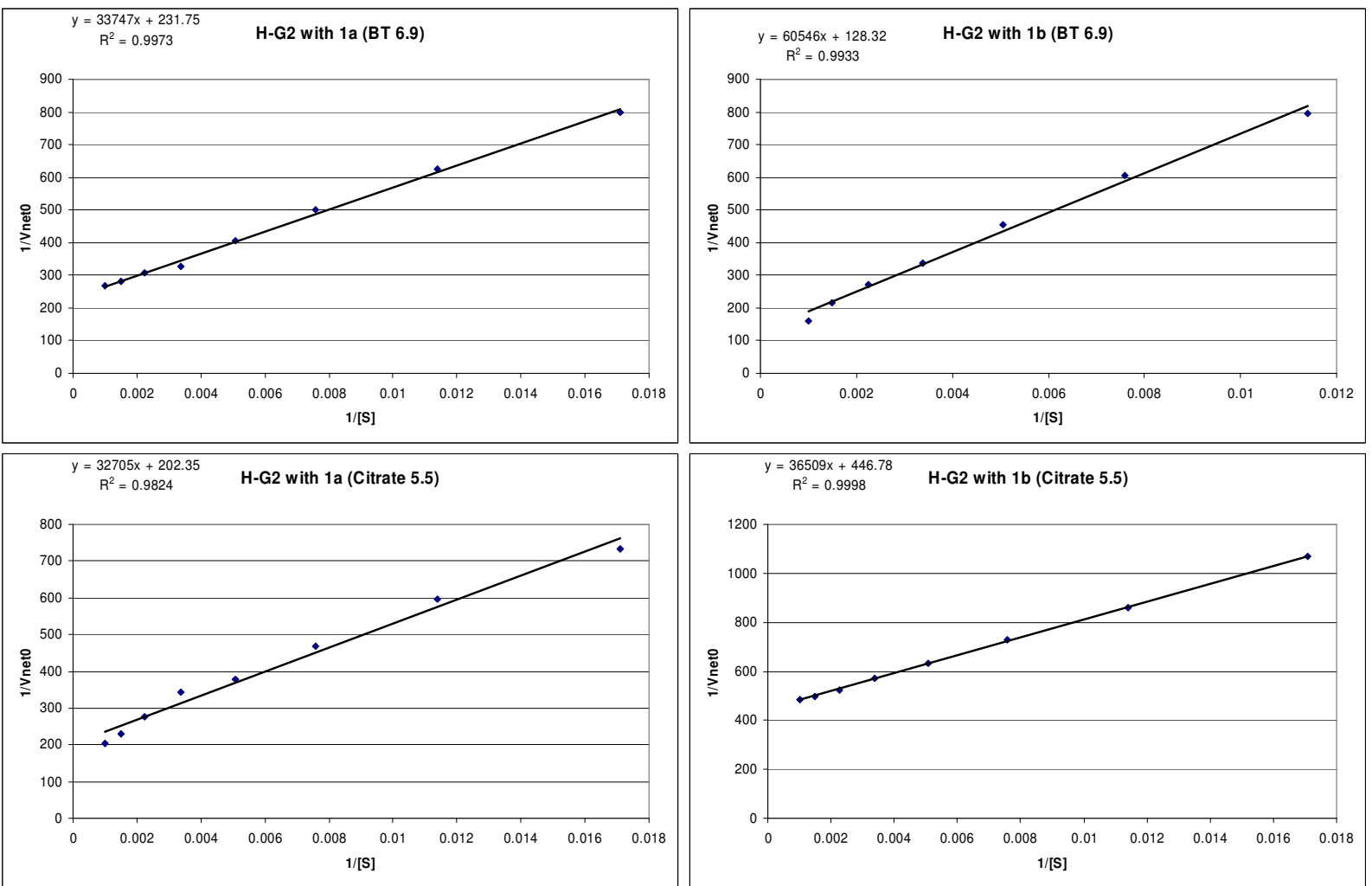


\section{Dendrimer H-G3: (((Ac-Ile-Pro $)_{2}$ Dap-Ile-Thr $)_{2}$ Dap-His-Ala $)_{2}$ Dap-His-Leu-NH ${ }_{2}$}

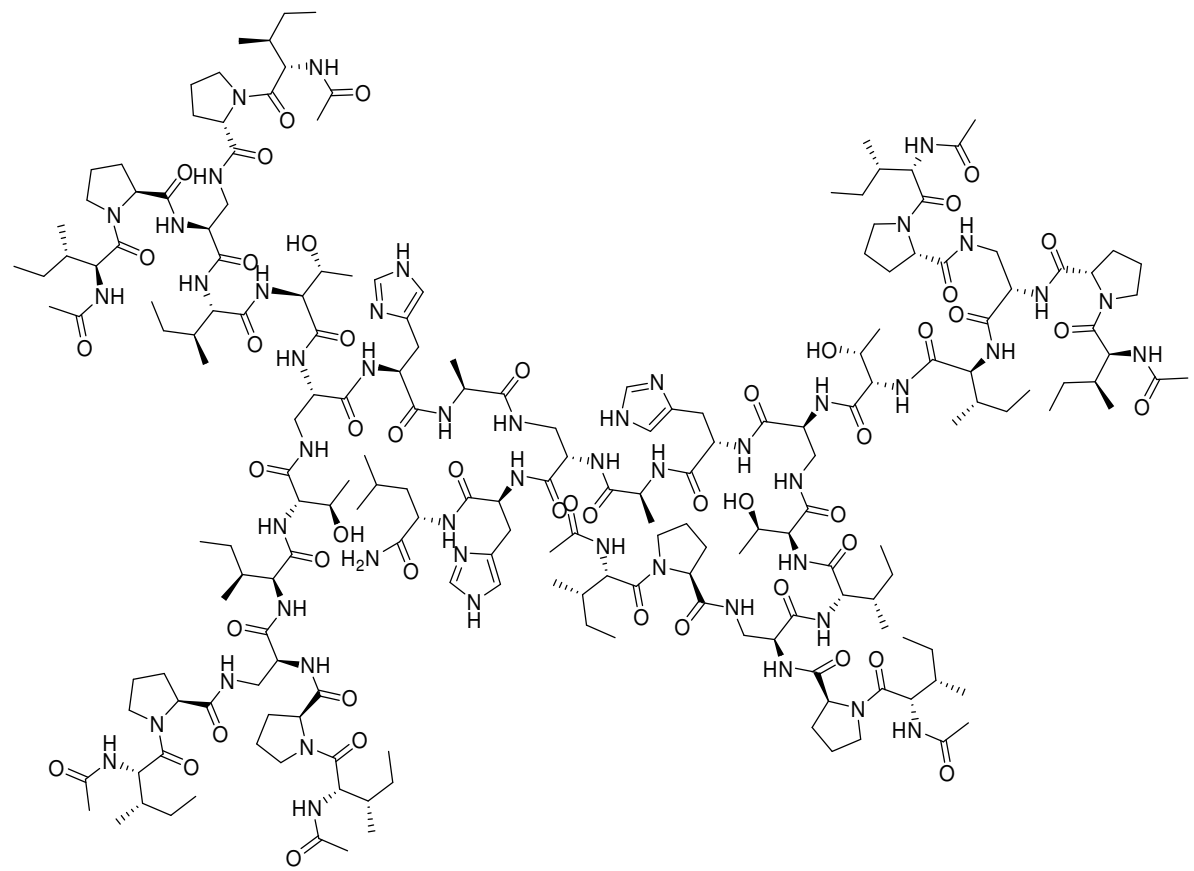

Starting with $250 \mathrm{mg}$ of NovaSyn ${ }^{\circledR}$ TGR resin $(0.26 \mathrm{mmol} / \mathrm{g})$, the dendrimer H-G3 was obtained using procedure A as colorless foamy solid after cleavage from the resin and preparative RPHPLC purification (46.7 mg, $16.0 \%$ ).

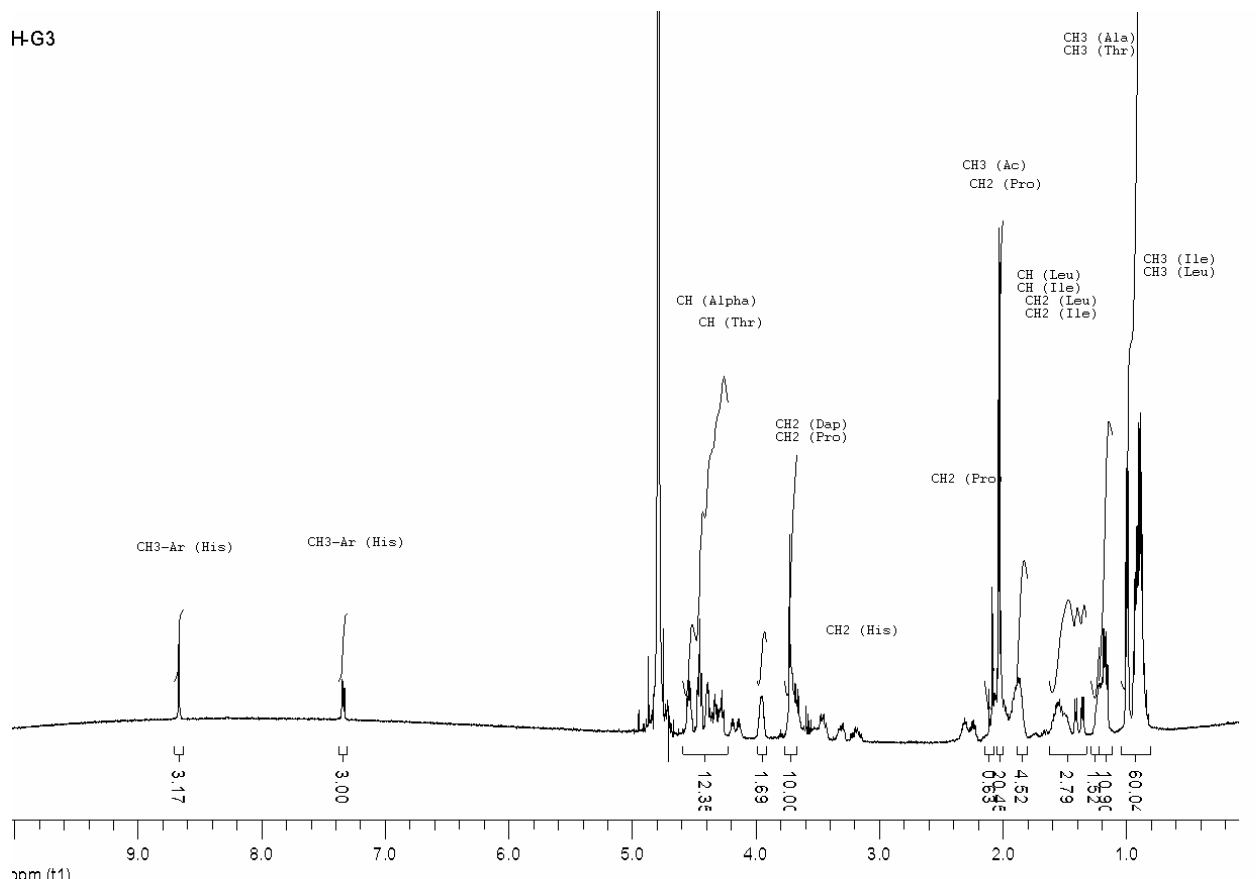


Preparative RP-HPLC: $t_{\mathrm{R}}=25 \mathrm{~min}(\mathrm{~A} / \mathrm{B}=50 / 50$ to $\mathrm{A} / \mathrm{B}=10 / 90$ in $40 \mathrm{~min})$

Analytical RP-HPLC: $t_{\mathrm{R}}=9.2 \mathrm{~min}(\mathrm{~A} / \mathrm{B}=50 / 50$ to $\mathrm{A} / \mathrm{B}=0 / 100$ in $15 \mathrm{~min})$

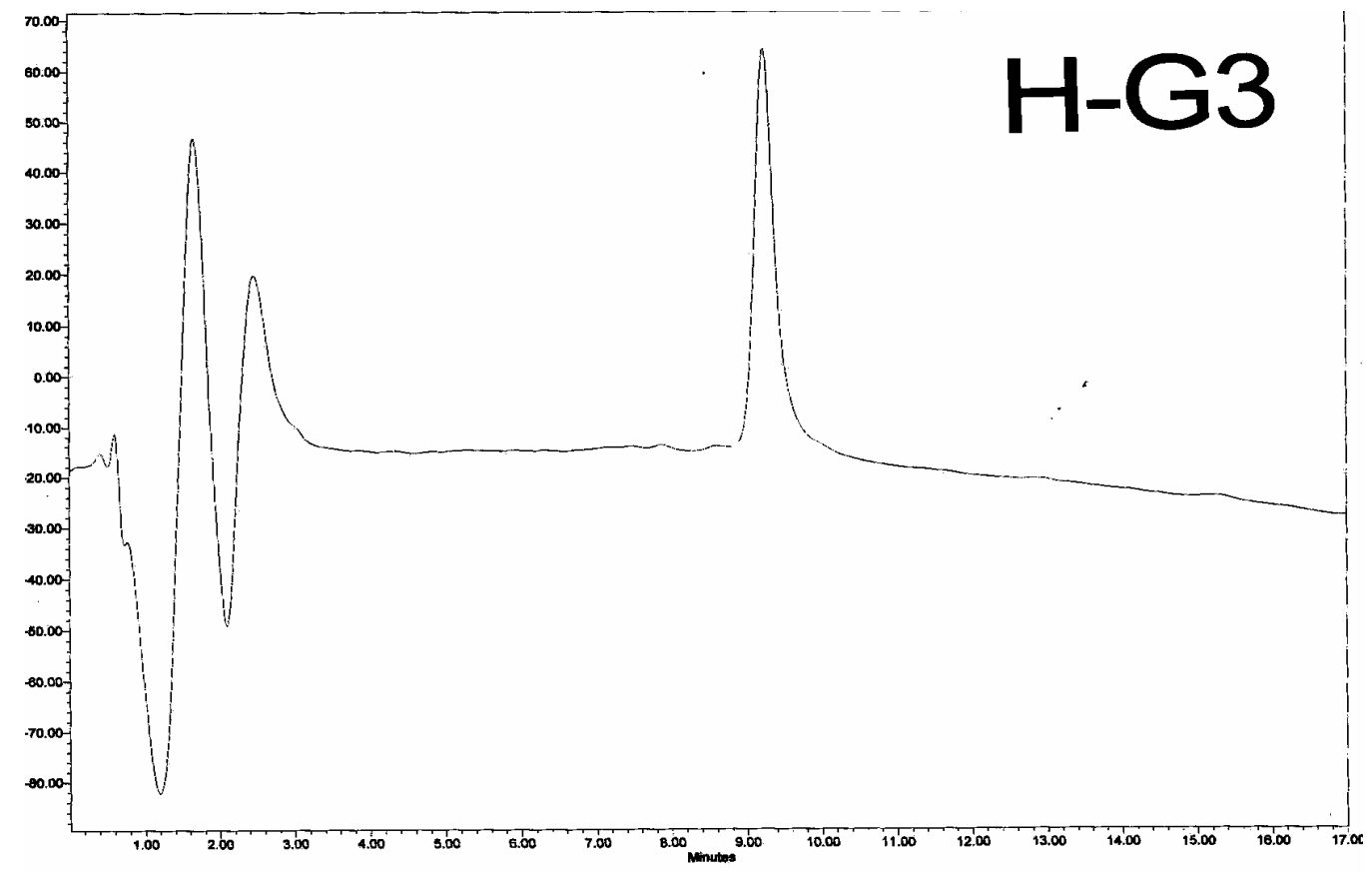

MS (ES+) calcd for $\mathrm{C}_{195} \mathrm{H}_{320} \mathrm{~N}_{51} \mathrm{O}_{49}[\mathrm{M}+\mathrm{H}]^{+}:$4160.4, found: 4162.2; $[\mathrm{M}+\mathrm{Na}]^{+}:$4182.2, found:

4183.8; $[\mathrm{M}+\mathrm{K}]^{+}:$4198.3, found: 4200.3.

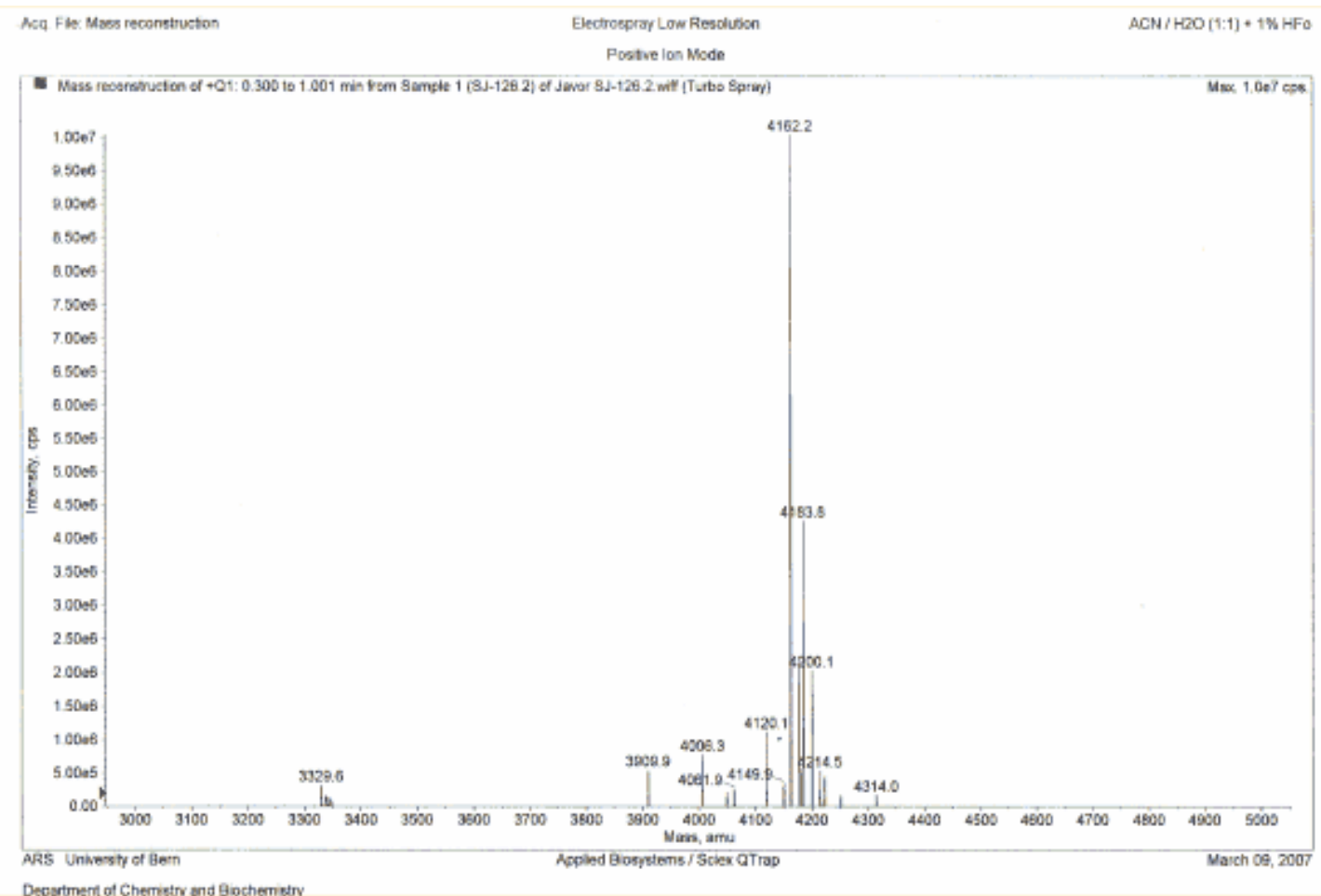


Michaelis-Menten plots for determination of $\boldsymbol{k}_{\text {cat }}$ and $\boldsymbol{K}_{\mathrm{M}}$
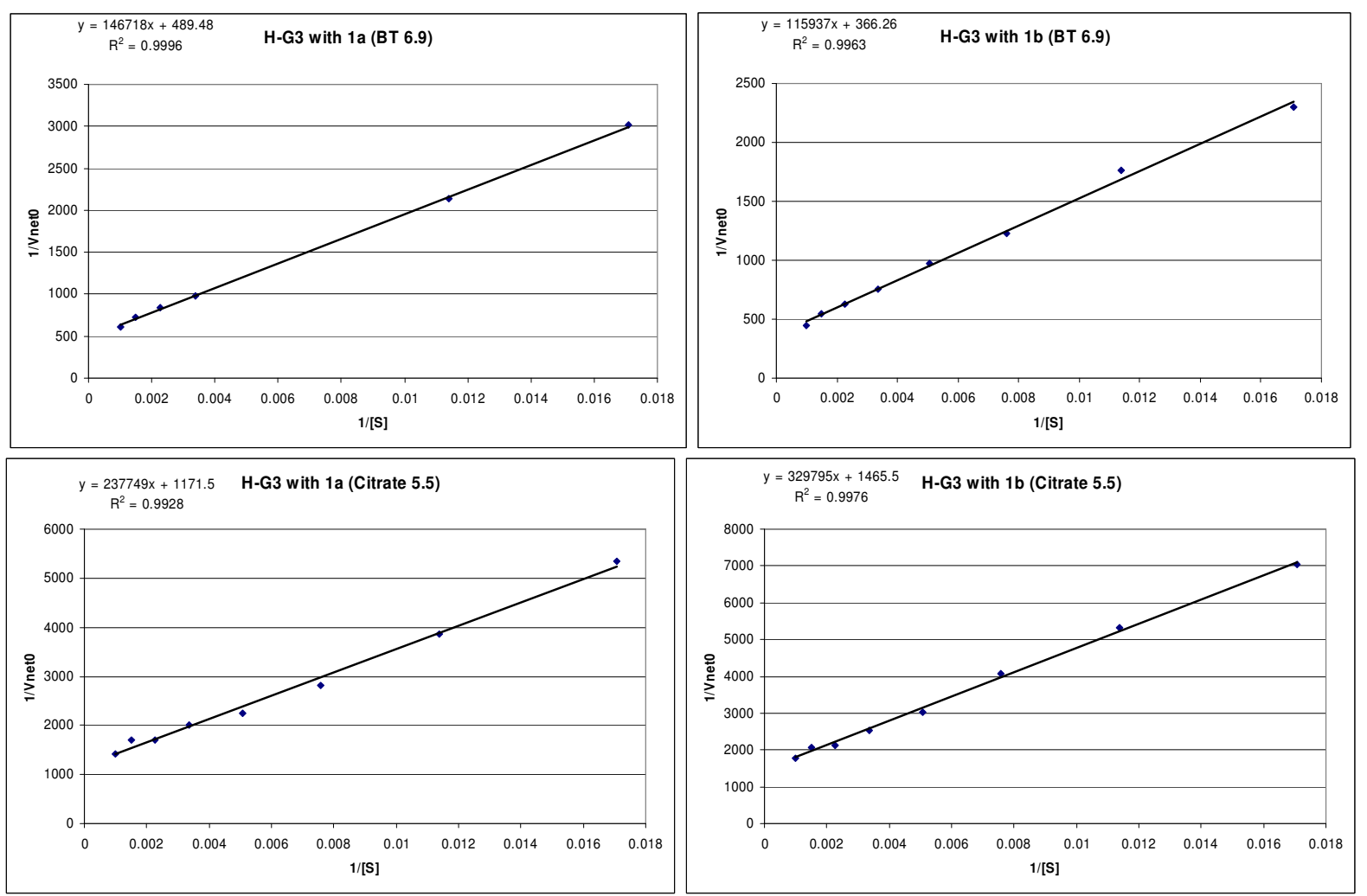


\section{Dendrimer HM-G1: (Ac-His-Ala-Gly) ${ }_{2}$ Dap-His-Leu-NH}

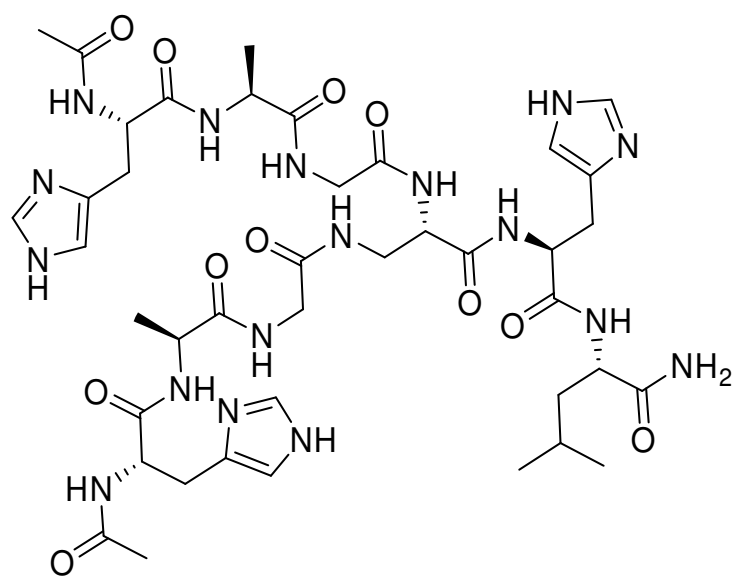

Starting with $250 \mathrm{mg}$ of NovaSyn ${ }^{\circledR}$ TGR resin $(0.23 \mathrm{mmol} / \mathrm{g})$, the dendrimer HM-G1 was obtained using procedure A as colorless foamy solid after cleavage from the resin and preparative RP-HPLC purification (40.1 mg, $53.2 \%$ ).

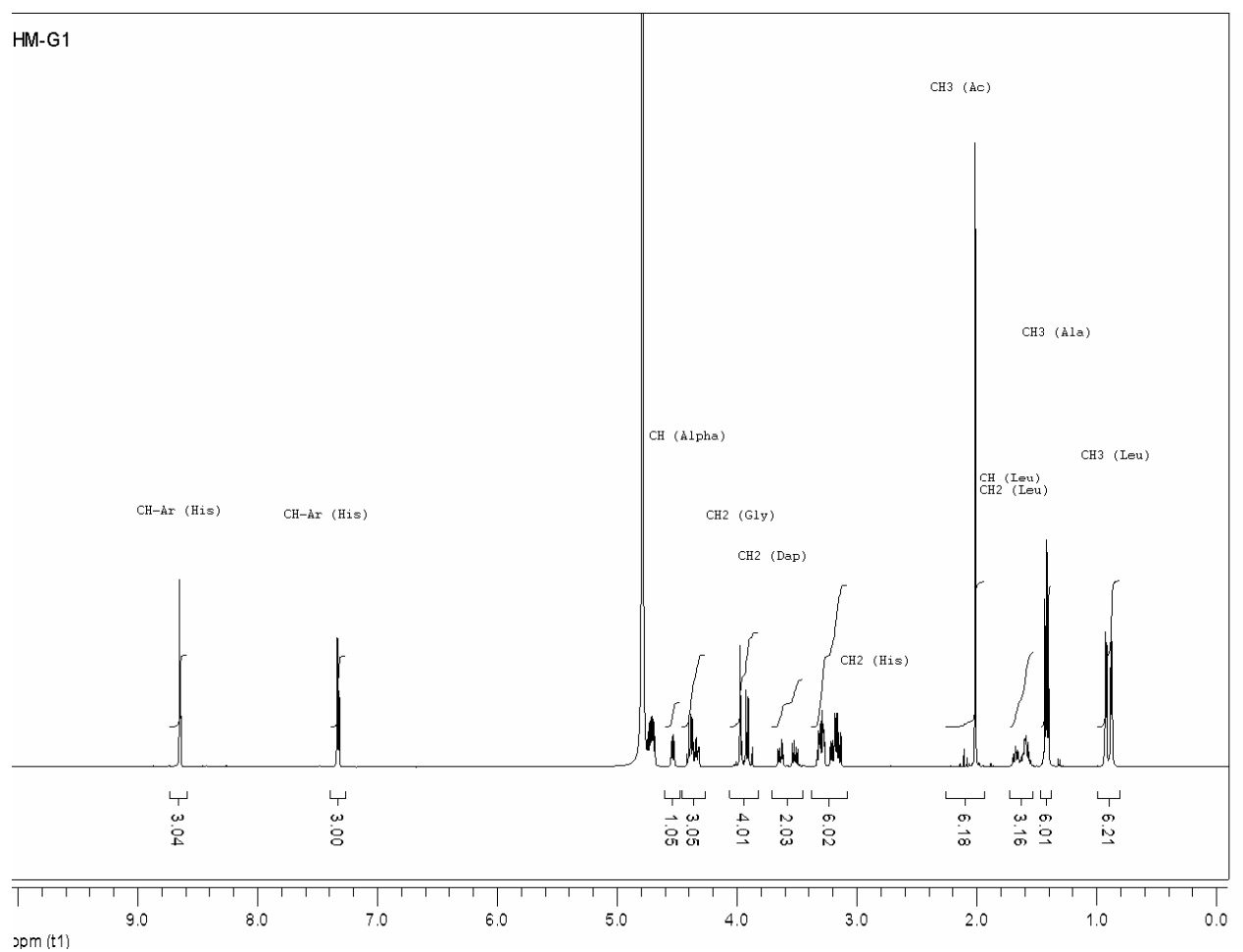


Preparative RP-HPLC: $t_{\mathrm{R}}=15 \min (\mathrm{A} / \mathrm{B}=95 / 5$ to $\mathrm{A} / \mathrm{B}=65 / 35$ in $30 \mathrm{~min})$

Analytical RP-HPLC: $t_{\mathrm{R}}=6.4 \mathrm{~min}(\mathrm{~A} / \mathrm{B}=100 / 0$ to $\mathrm{A} / \mathrm{B}=60 / 40$ in $8 \mathrm{~min})$

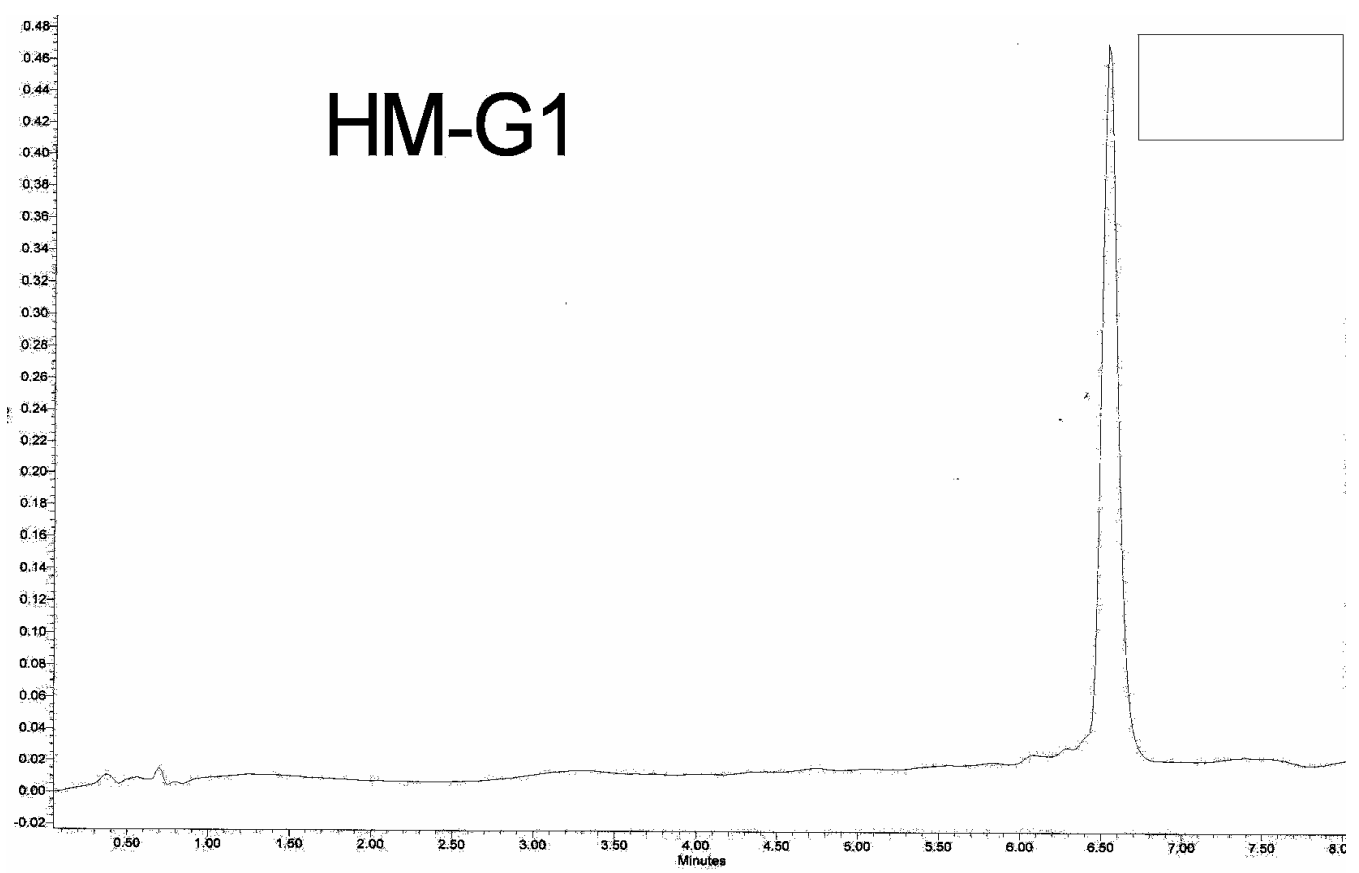

MS (ES+) calcd for $\mathrm{C}_{41} \mathrm{H}_{62} \mathrm{~N}_{17} \mathrm{O}_{11}[\mathrm{M}+\mathrm{H}]^{+}$: 968.5, found: 968.6; [M+Na]+: 990.5, found: 990.6;

$[\mathrm{M}+2 \mathrm{H}]^{2+} / 2: 484.8$, found: $485.0 ;[\mathrm{M}+3 \mathrm{H}]^{3+} / 3: 323.5$, found: 323.8 .

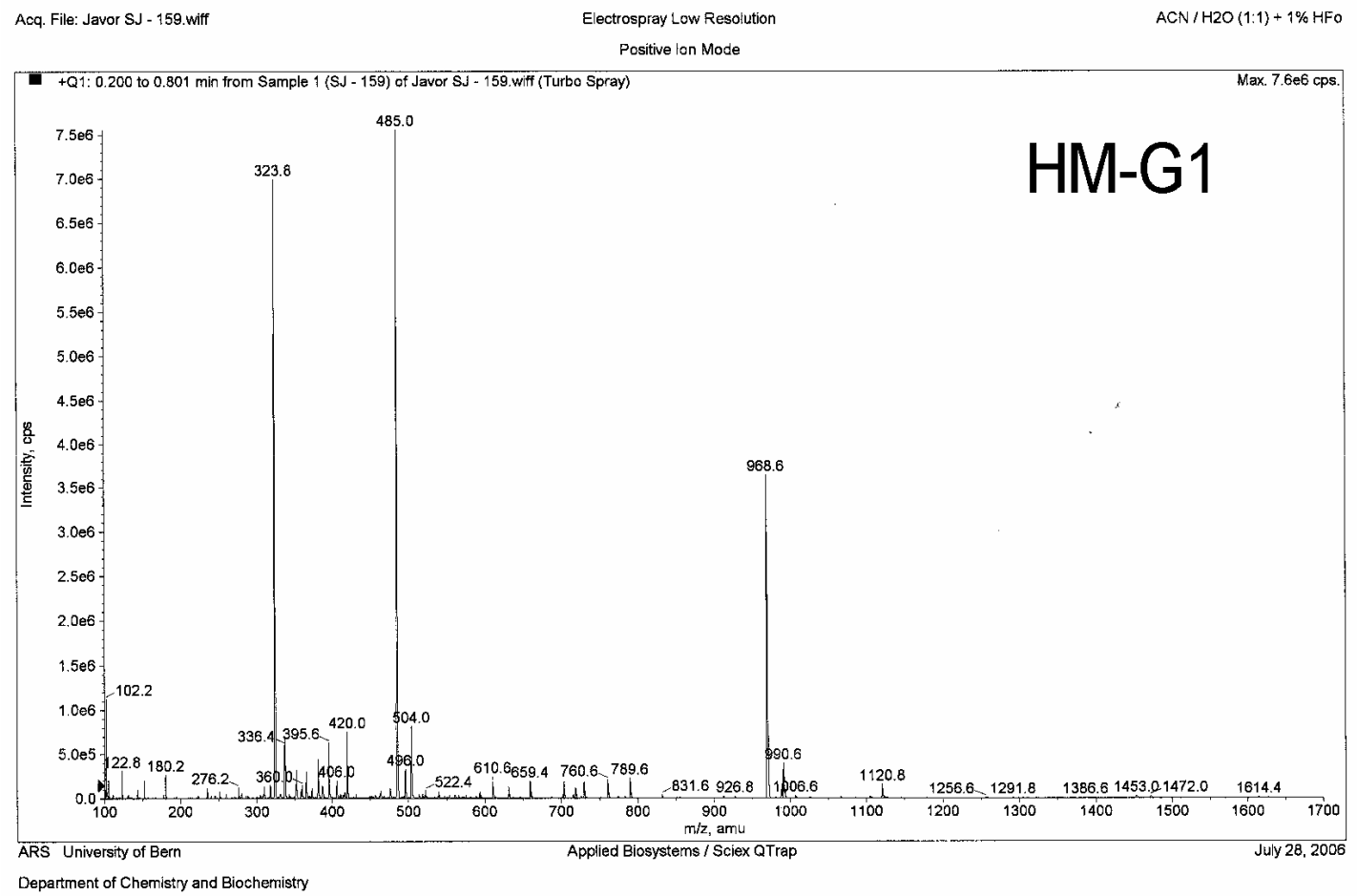


Michaelis-Menten plots for determination of $\boldsymbol{k}_{\text {cat }}$ and $\boldsymbol{K}_{\mathbf{M}}$
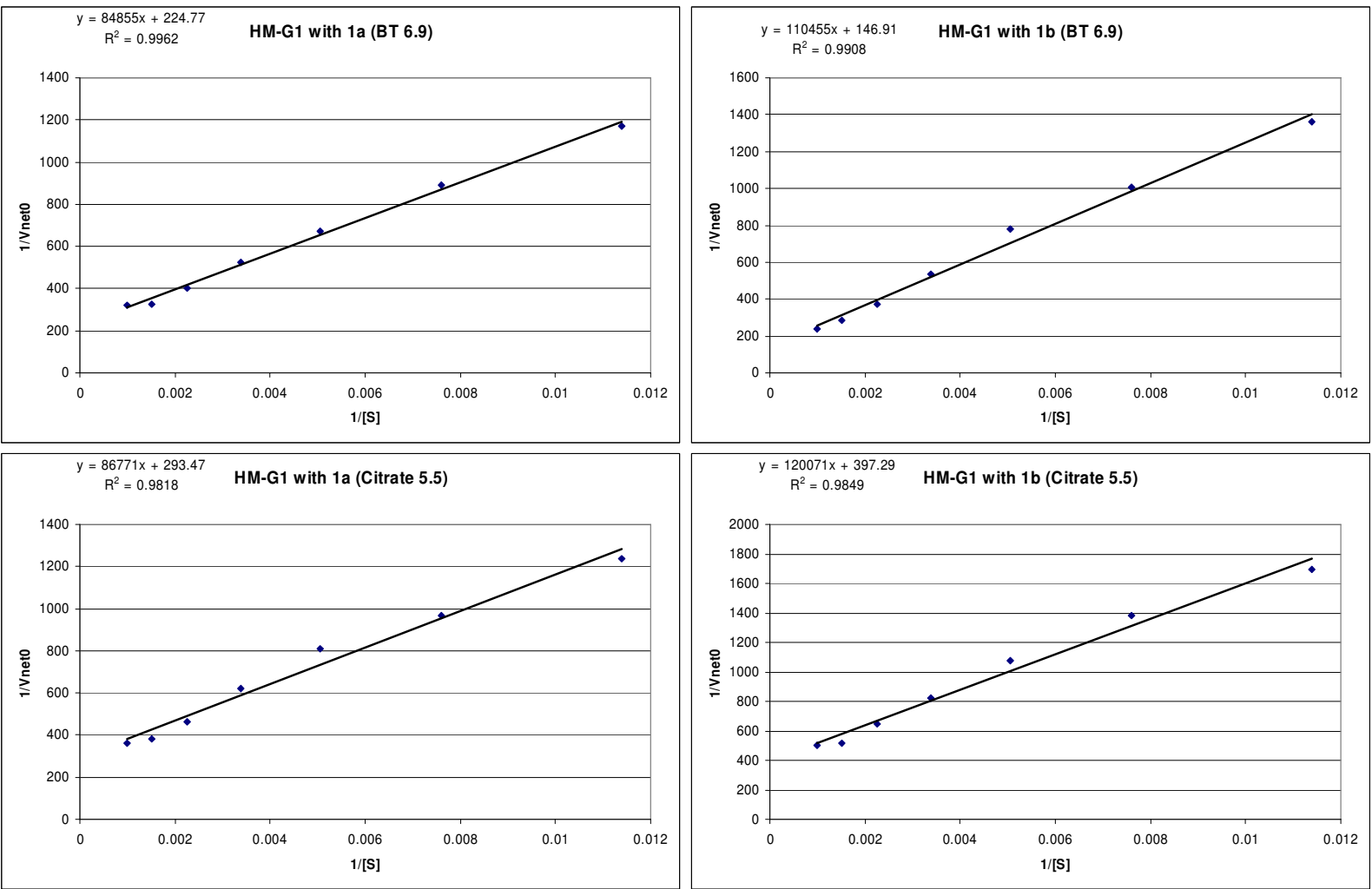


\section{Dendrimer HM-G2: ((Ac- Ile-Thr $)_{2}$ Dap-His-Ala-Gly $)_{2}$ Dap-His-Leu-NH}

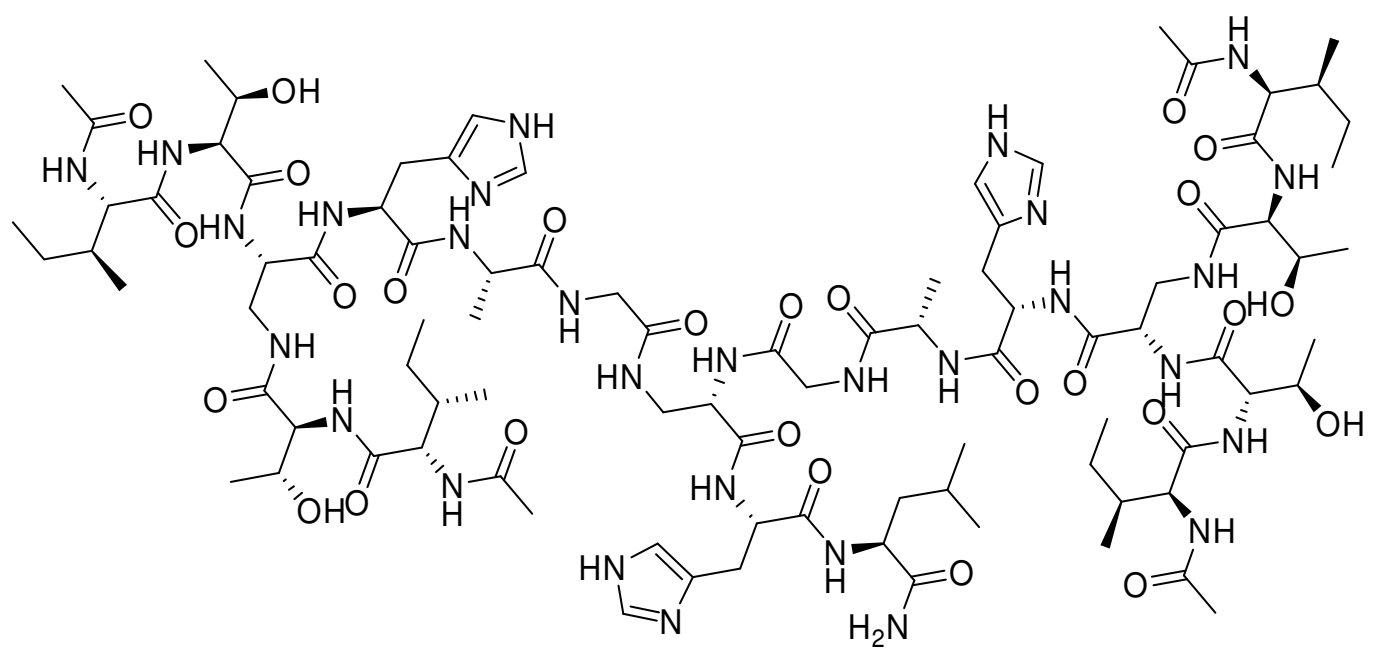

Starting with $250 \mathrm{mg}$ of NovaSyn ${ }^{\circledR}$ TGR resin $(0.23 \mathrm{mmol} / \mathrm{g})$, the dendrimer HM-G2 was obtained using procedure A as colorless foamy solid after cleavage from the resin and preparative RP-HPLC purification (35.5 mg, $25.5 \%$ ).

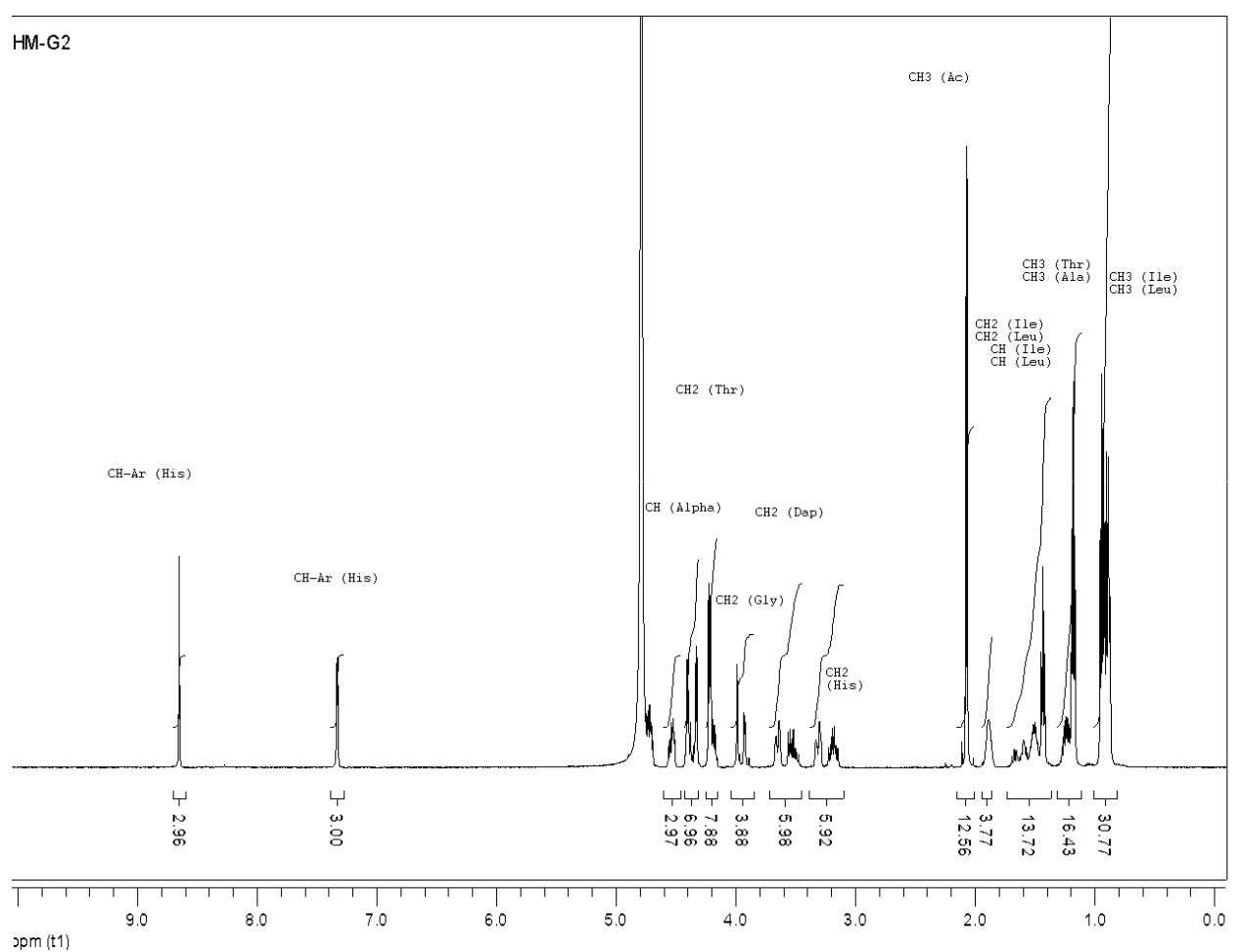


Preparative RP-HPLC: $t_{\mathrm{R}}=25 \min (\mathrm{A} / \mathrm{B}=70 / 30$ to $\mathrm{A} / \mathrm{B}=30 / 70$ in $40 \mathrm{~min})$ Analytical RP-HPLC: $t_{\mathrm{R}}=6.2 \mathrm{~min}(\mathrm{~A} / \mathrm{B}=70 / 30$ to $\mathrm{A} / \mathrm{B}=35 / 65$ in $7.5 \mathrm{~min})$

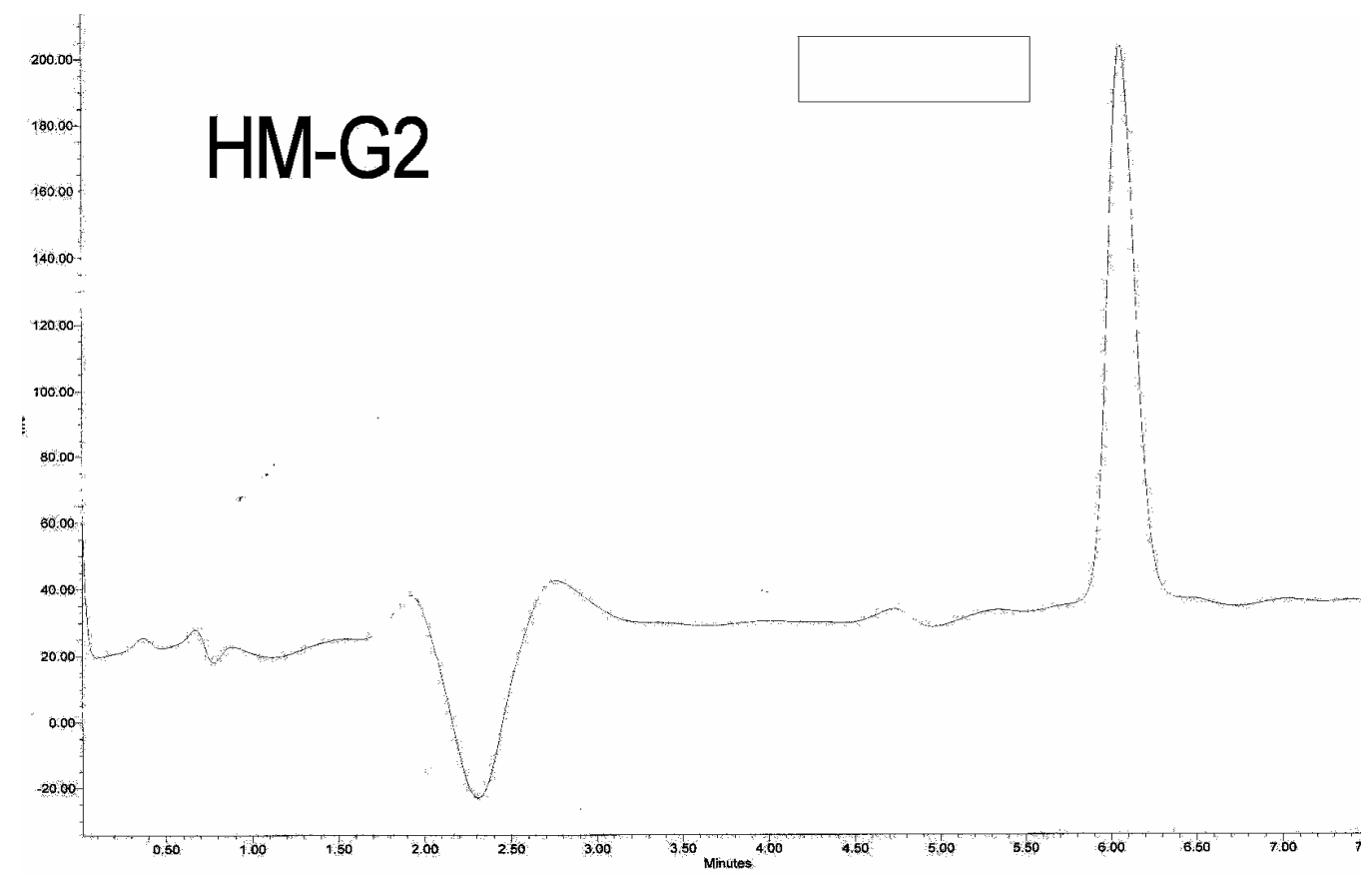

MS (ES+) calcd for $\mathrm{C}_{91} \mathrm{H}_{150} \mathrm{~N}_{29} \mathrm{O}_{27}[\mathrm{M}+\mathrm{H}]^{+}:$2081.1, found: 2081.4; [M+Na] $]^{+}:$2103.1, found: 2103.6; $[\mathrm{M}+\mathrm{K}]^{+}:$2119.2, found: 2119.2 .

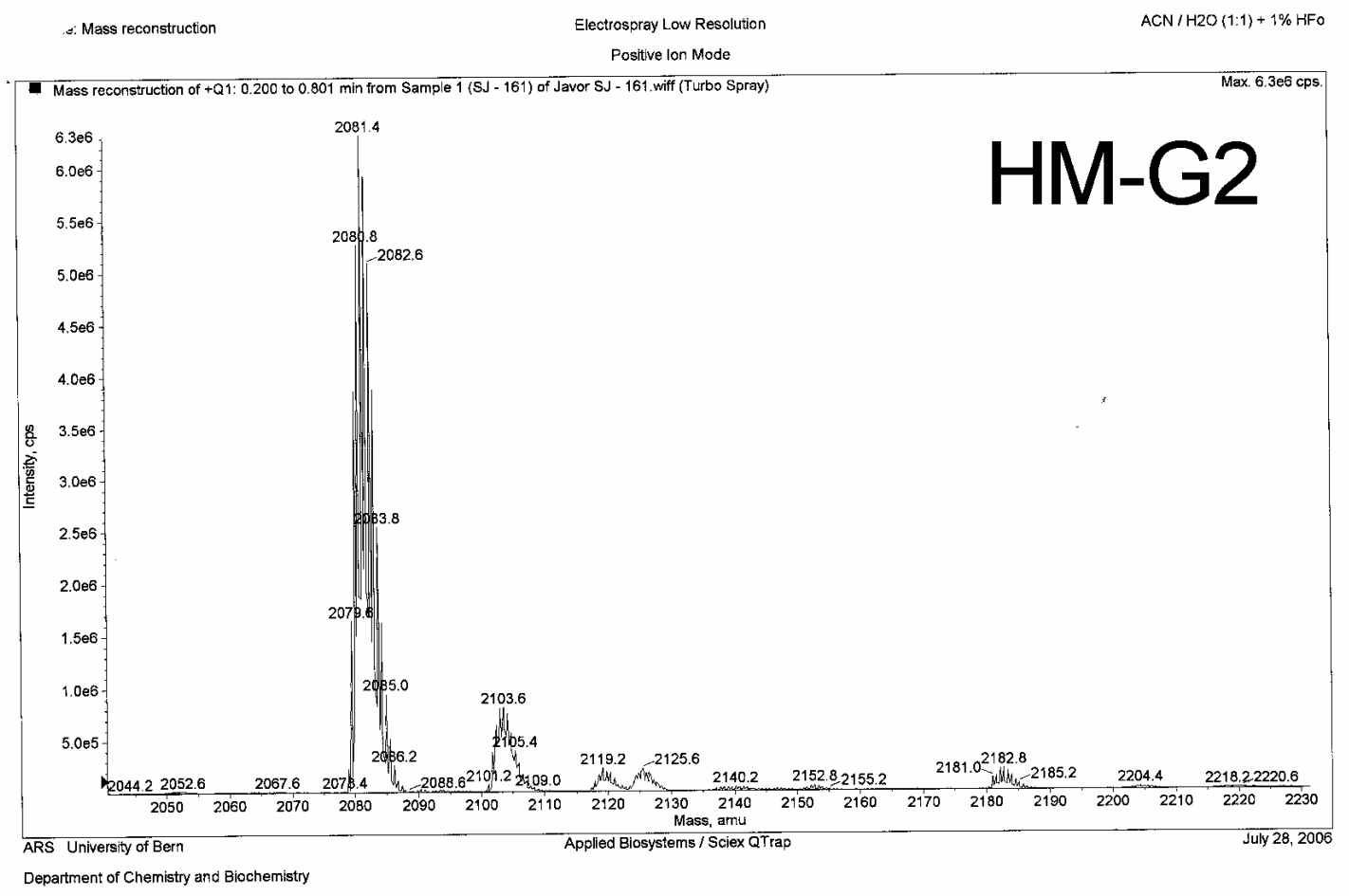


Michaelis-Menten plots for determination of $\boldsymbol{k}_{c a t}$ and $\boldsymbol{K}_{M}$
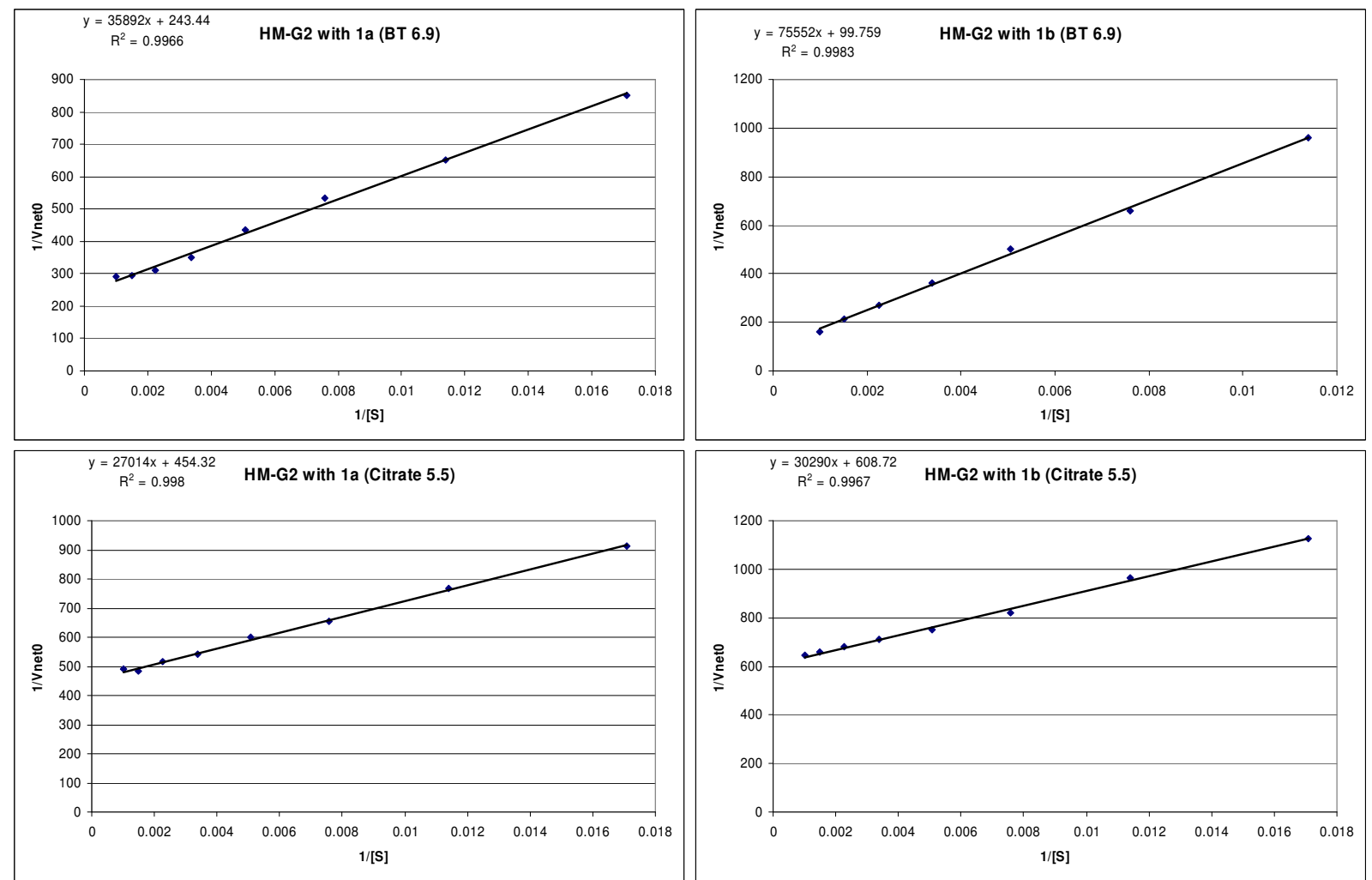


\section{Dendrimer HM-G3: (((Ac-Ile-Pro $)_{2}$ Dap-Ile-Thr $)_{2}$ Dap-His-Ala-Gly $)_{2}$ Dap-His-Leu-NH ${ }_{2}$}

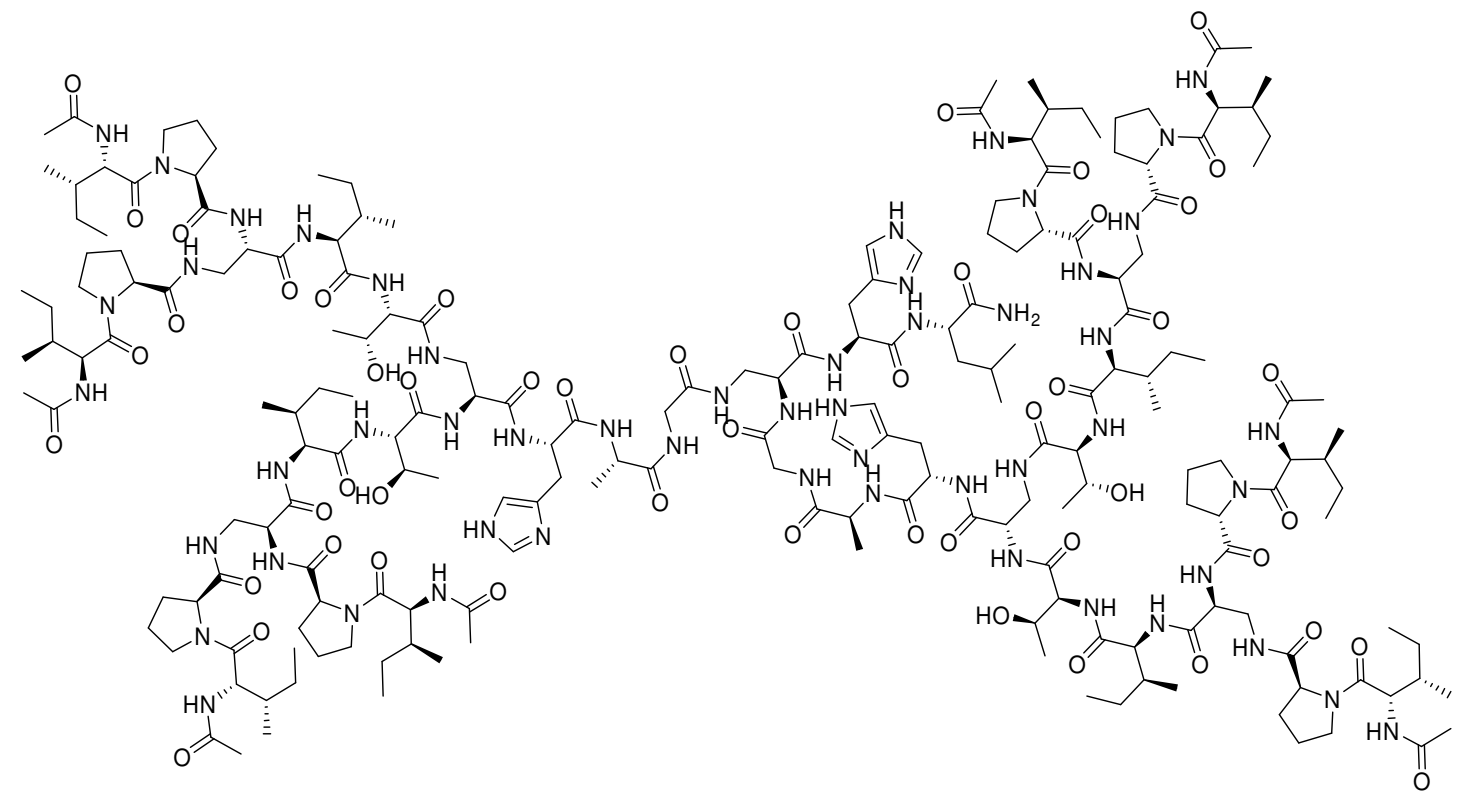

Starting with $250 \mathrm{mg}$ of NovaSyn ${ }^{\circledR}$ TGR resin $(0.26 \mathrm{mmol} / \mathrm{g})$, the dendrimer HM-G3 was obtained using procedure A as colorless foamy solid after cleavage from the resin and preparative RP-HPLC purification (28.6 mg, $9.5 \%$ ).

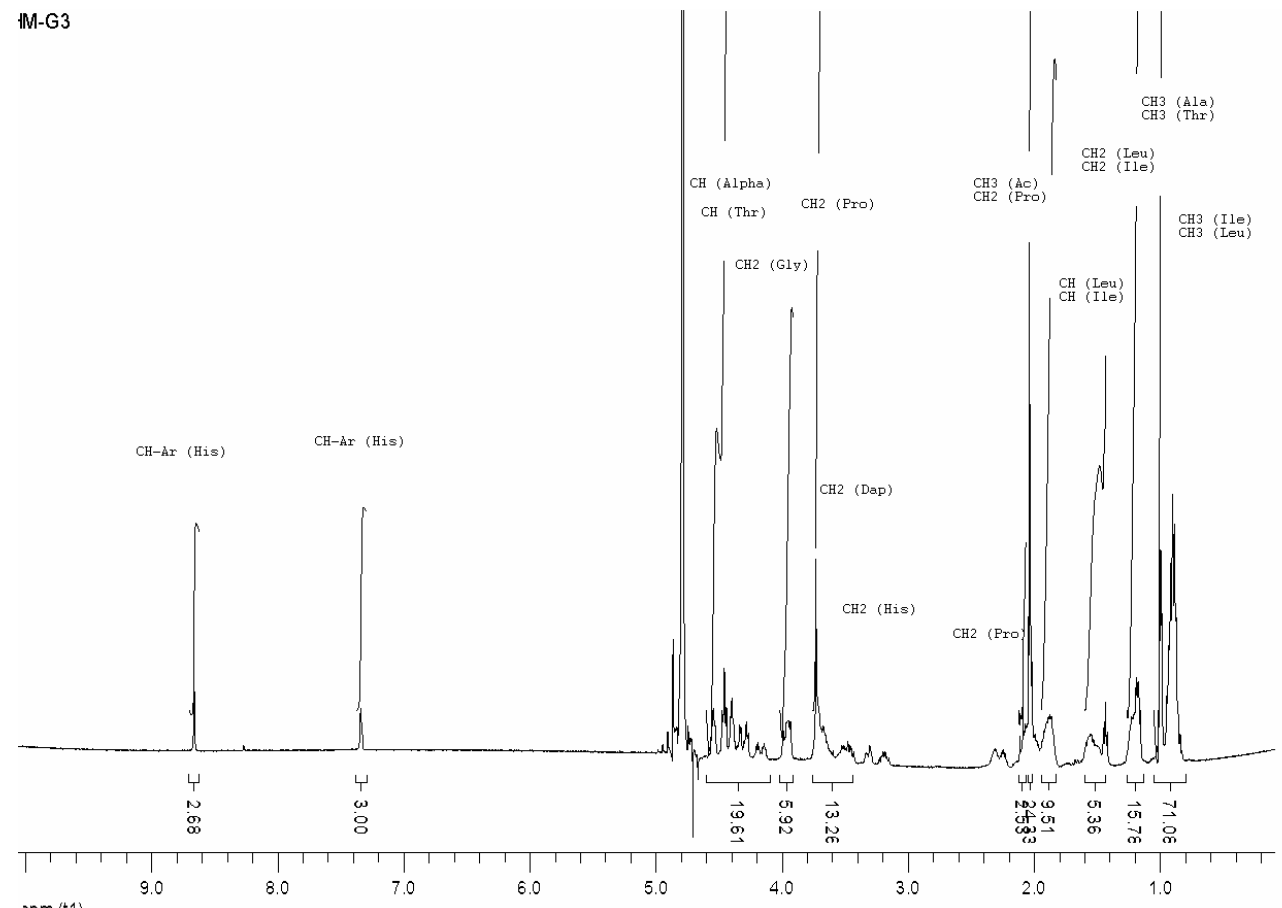


Preparative RP-HPLC: $t_{\mathrm{R}}=25 \mathrm{~min}(\mathrm{~A} / \mathrm{B}=50 / 50$ to $\mathrm{A} / \mathrm{B}=10 / 90$ in $40 \mathrm{~min})$

Analytical RP-HPLC: $t_{\mathrm{R}}=9.3 \mathrm{~min}(\mathrm{~A} / \mathrm{B}=50 / 50$ to $\mathrm{A} / \mathrm{B}=0 / 100$ in $15 \mathrm{~min})$

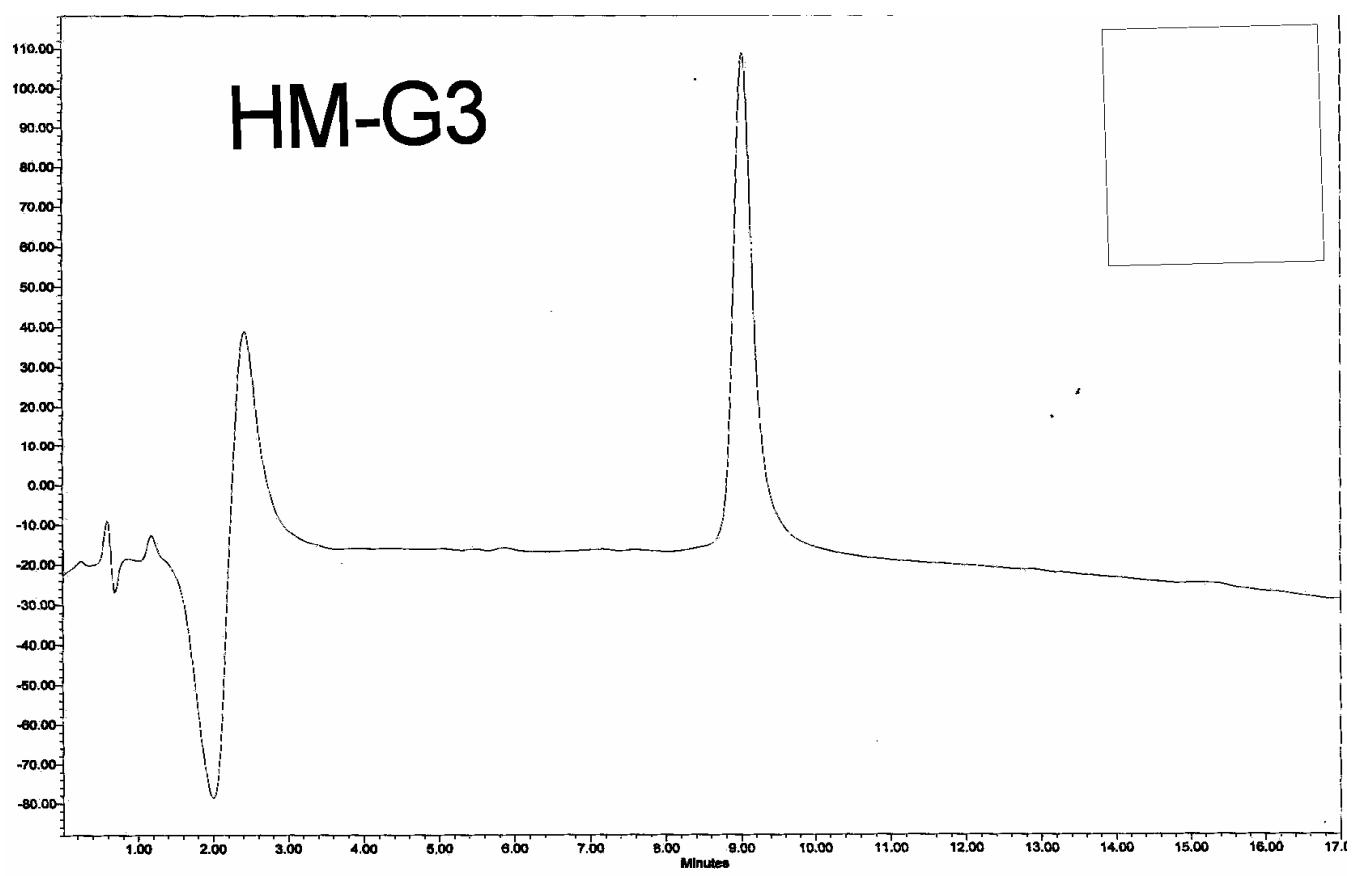

MS (ES+) calcd for $\mathrm{C}_{199} \mathrm{H}_{326} \mathrm{~N}_{53} \mathrm{O}_{51}[\mathrm{M}+\mathrm{H}]^{+}:$4274.5, found: 4277.4; $[\mathrm{M}+\mathrm{Na}]^{+}$: 4296.5, found: 4299.2; $[\mathrm{M}+\mathrm{K}]^{+}:$4312.6, found: 4315.2.

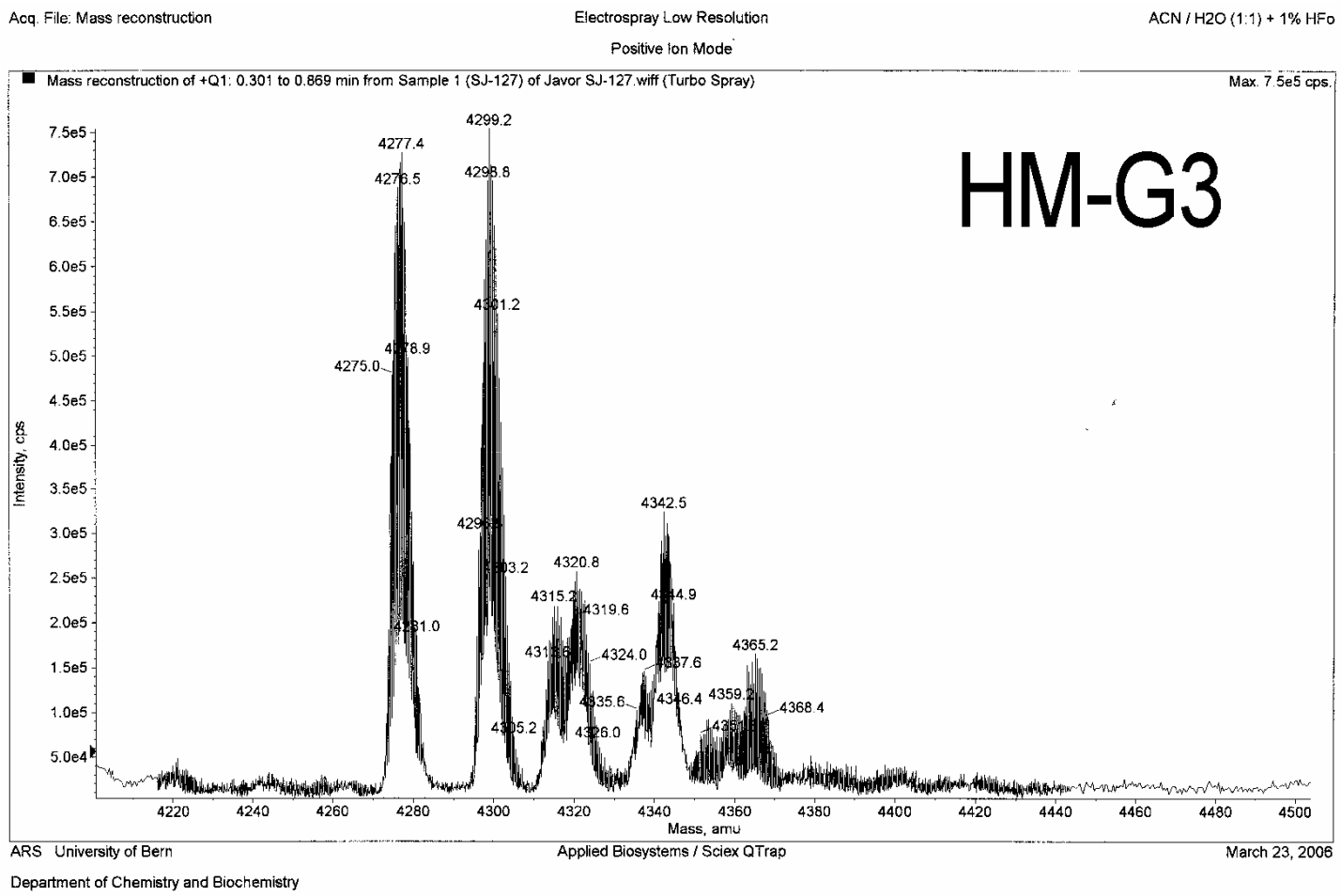


Michaelis-Menten plots for determination of $\boldsymbol{k}_{c a t}$ and $\boldsymbol{K}_{M}$
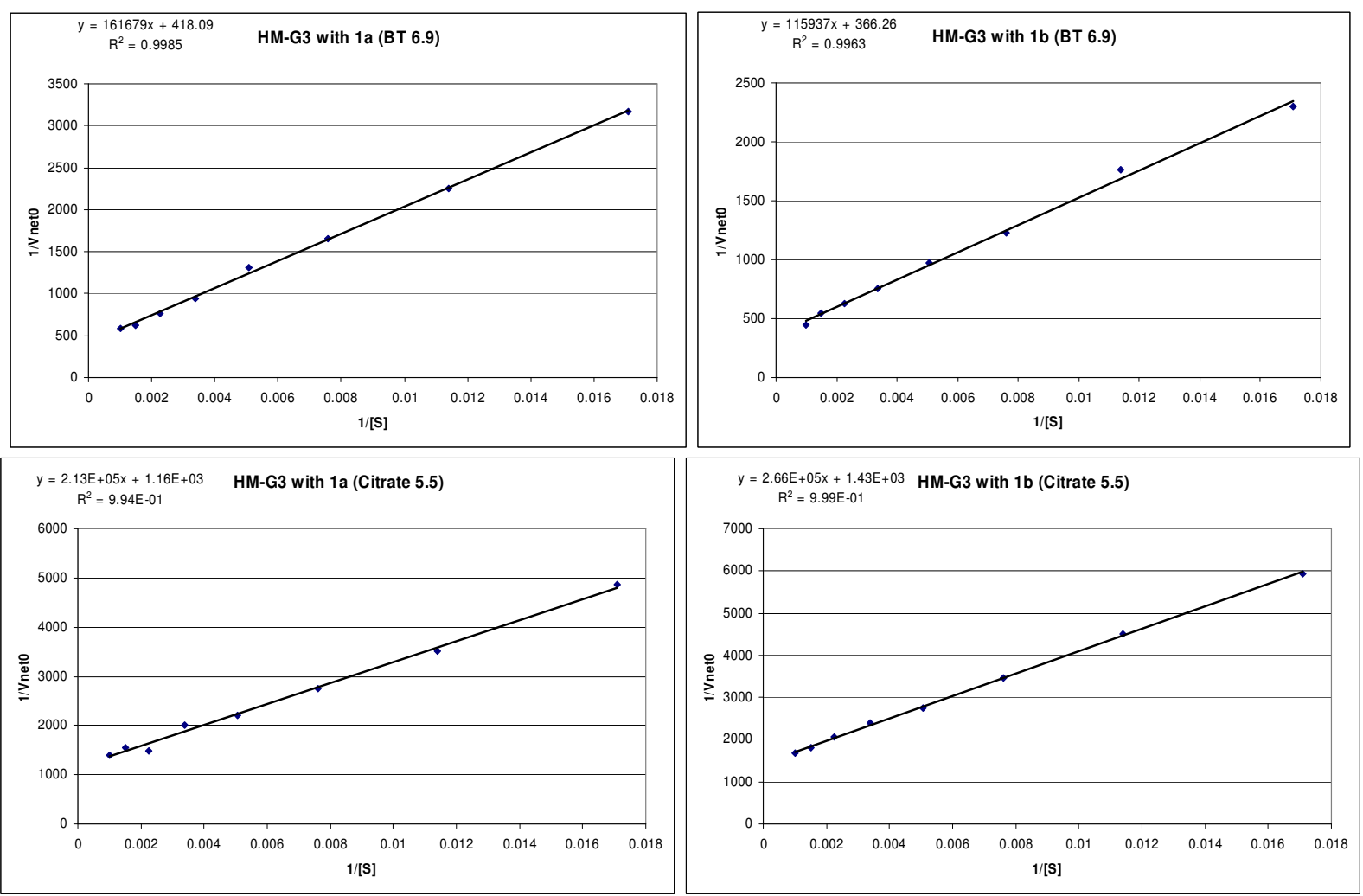


\section{pH profile Michaelis-Menten plots}

\section{Dendrimer R-G3}
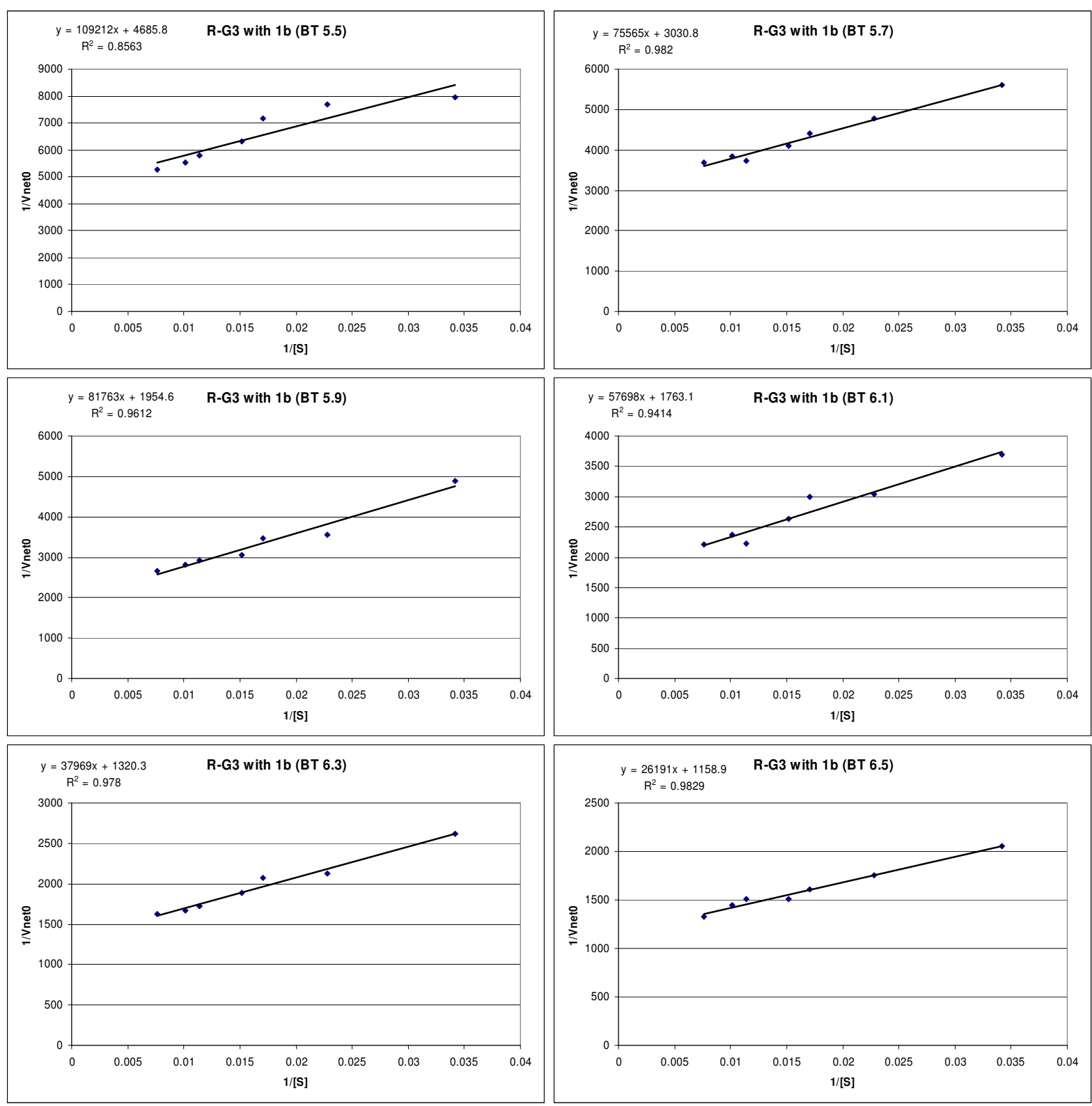

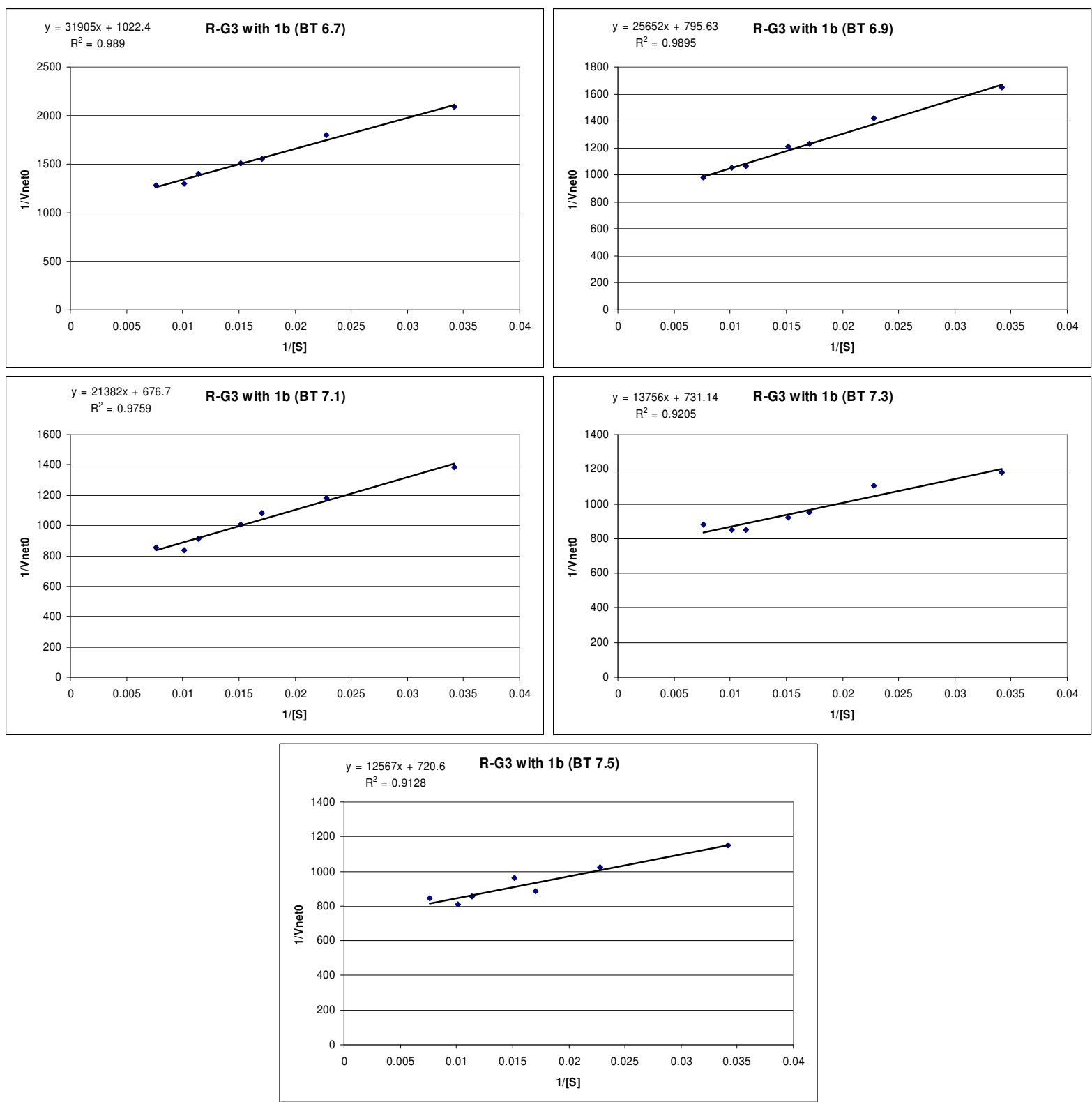


\section{Dendrimer H-G3}
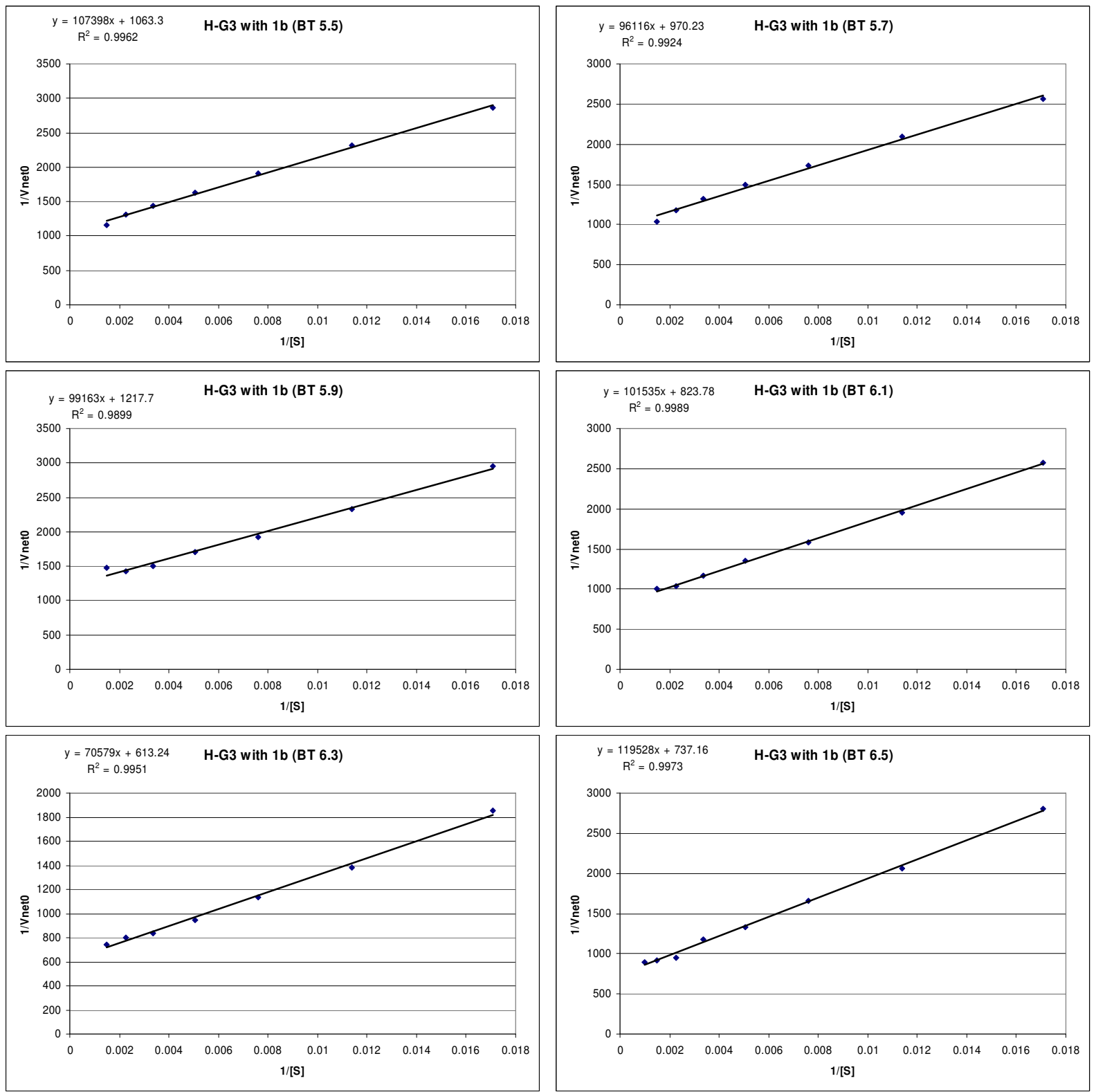

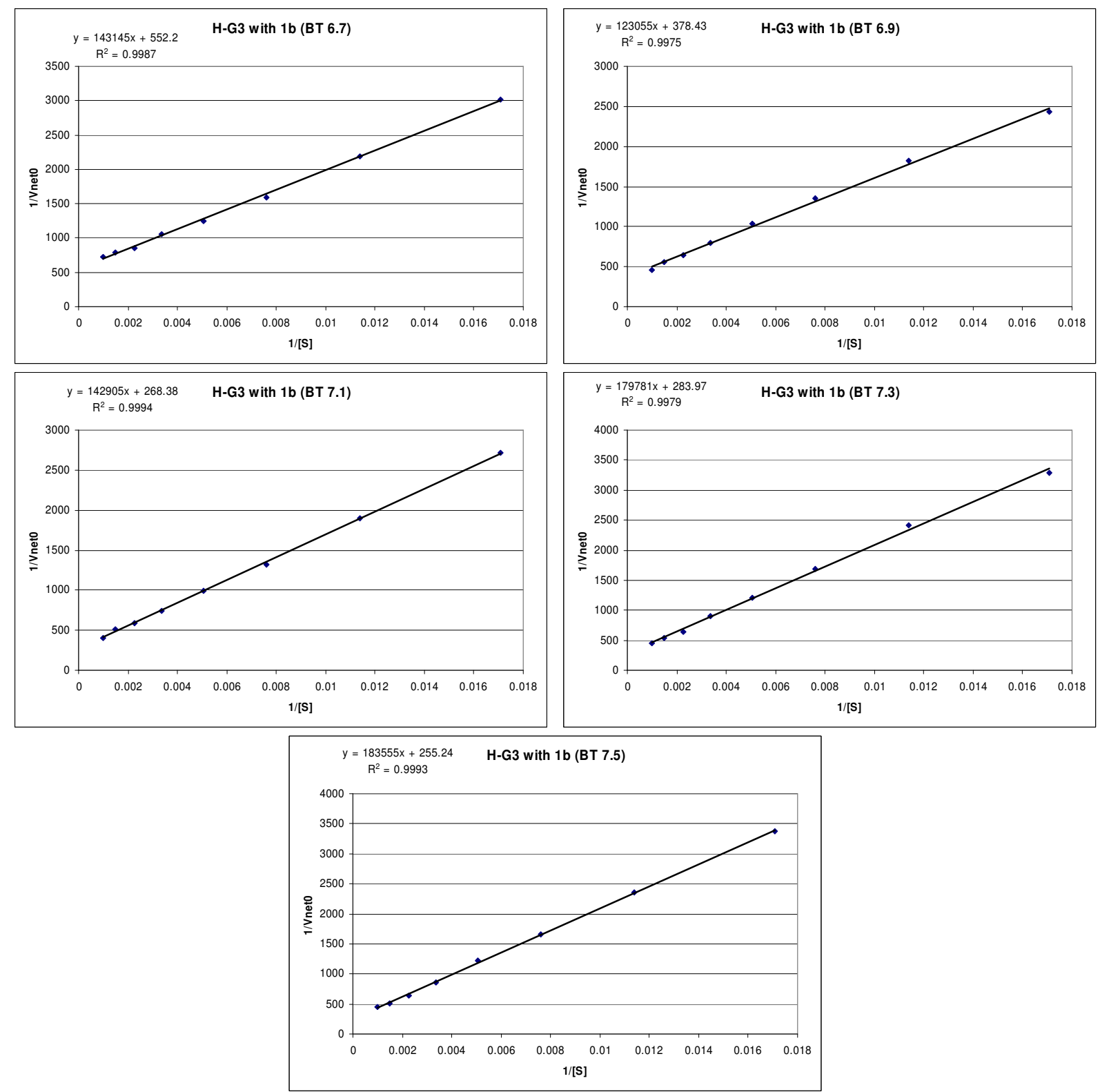


\section{Dendrimer RM-G3}
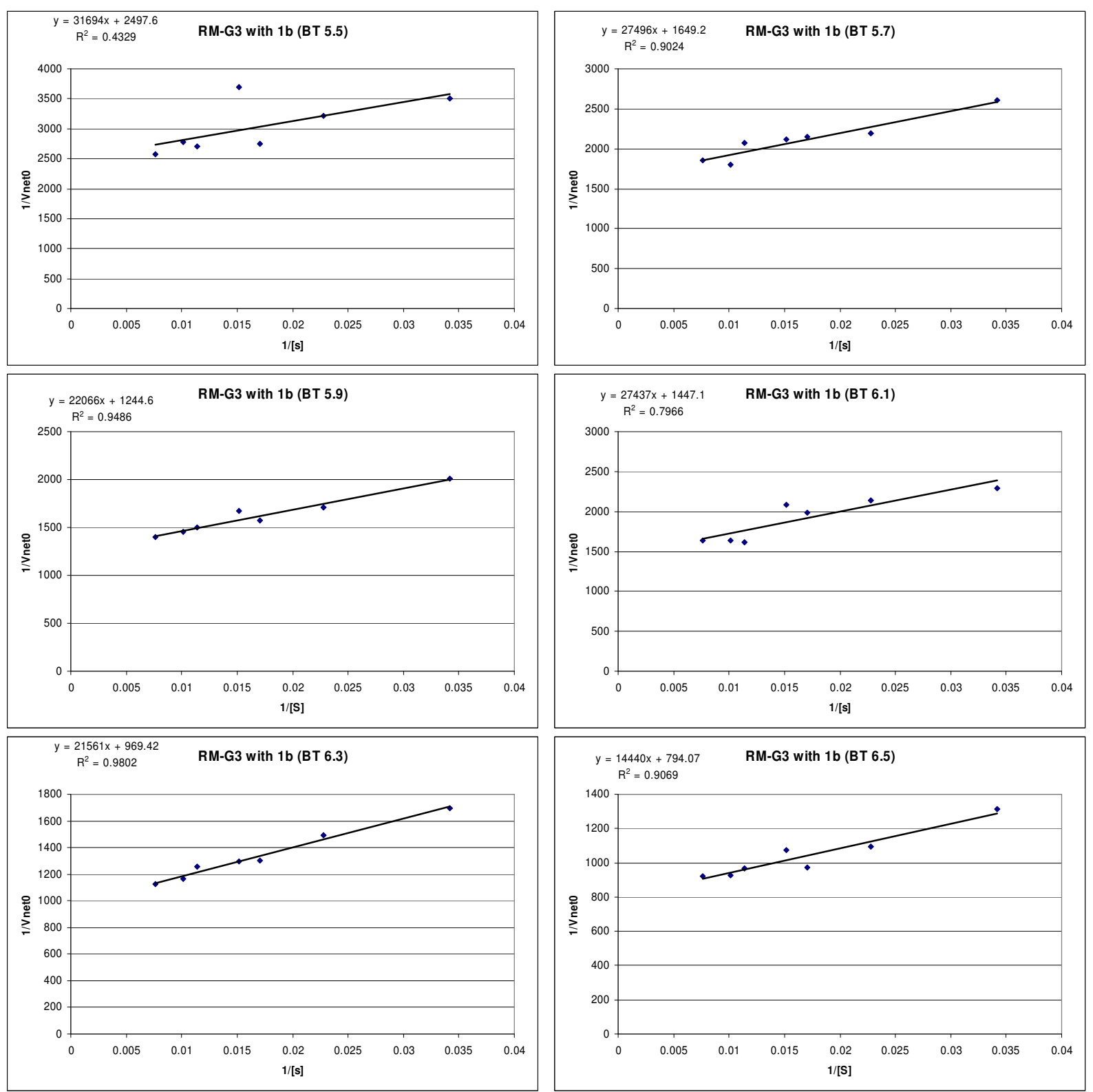

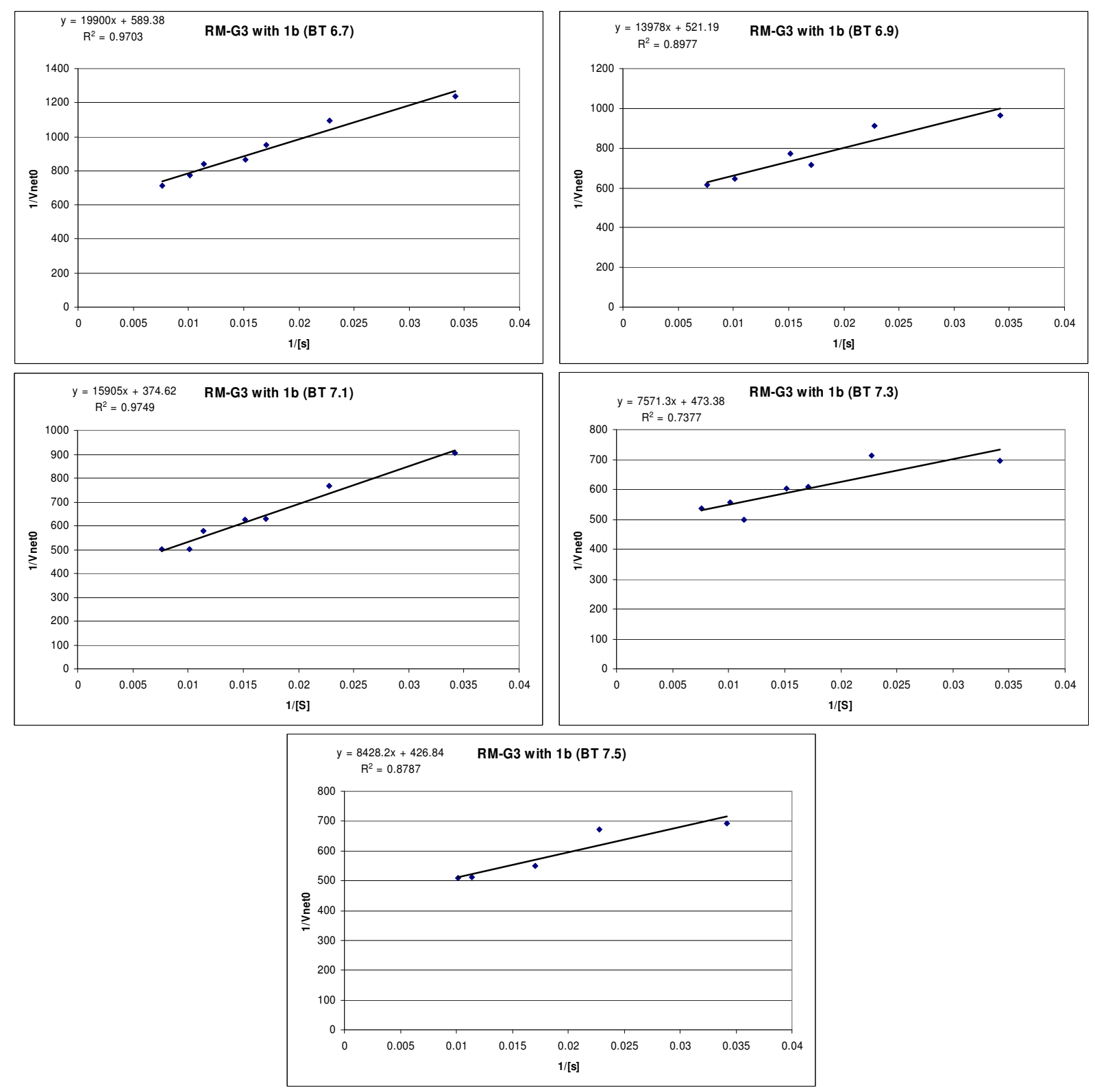


\section{Dendrimer HM-G3}
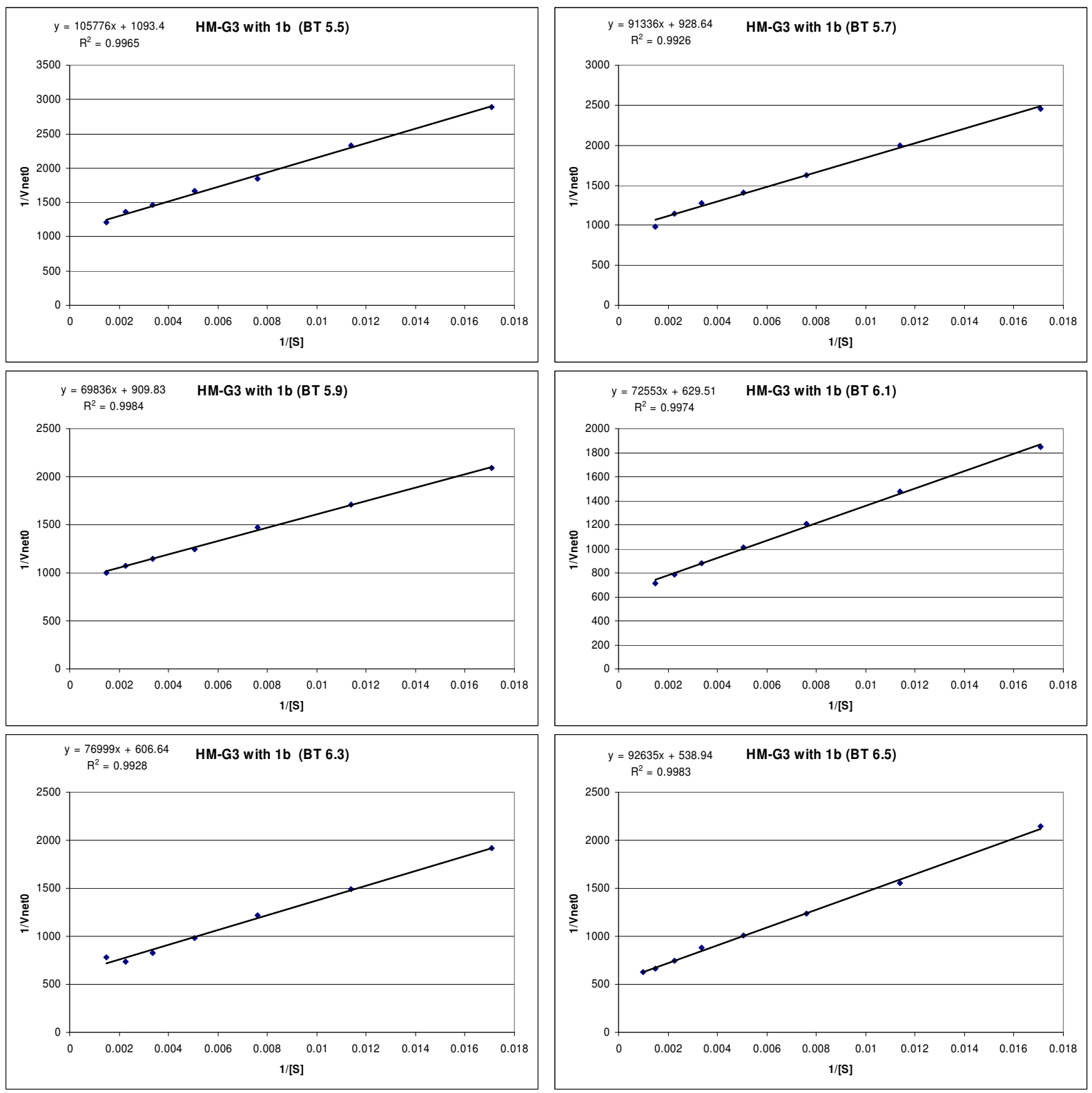

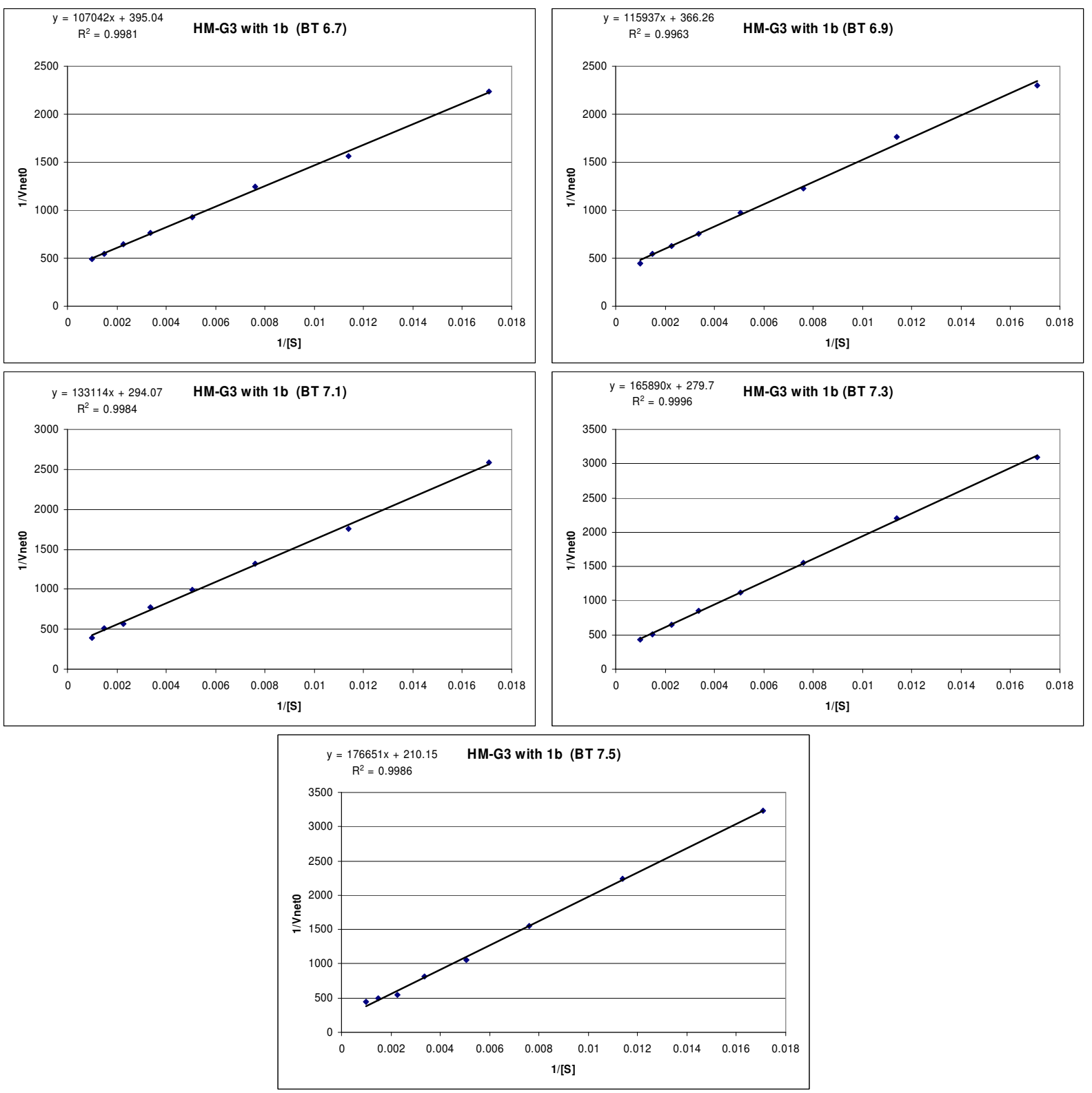


\section{pH profiles}
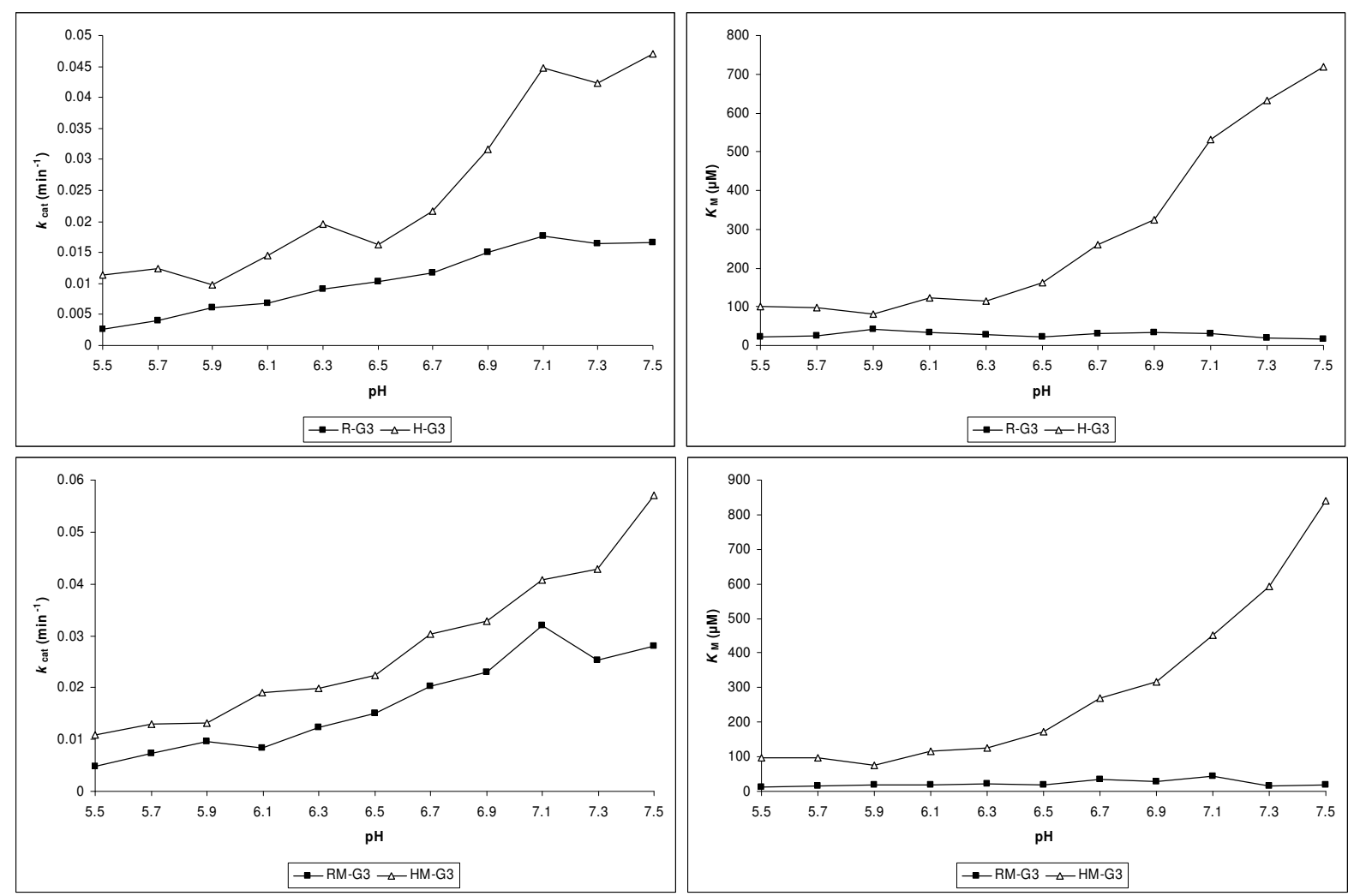

\section{Diffusion coefficients and calculated radii}

The following diffusion coefficients D are median values from 3-8 analysis (area fit or intensity fit) of different ${ }^{1} \mathrm{H}$ signals. $\sigma$ is the standard deviation.

\begin{tabular}{cccccc}
\hline Sequence & $\mathbf{M W}(\mathbf{D a})$ & residues & $\mathbf{D}\left(\mathbf{m}^{\mathbf{2}} \mathbf{s}^{-\mathbf{1}}\right)$ & $\boldsymbol{\sigma}(\boldsymbol{\%})$ & $\mathbf{R}_{\mathbf{h}}(\mathbf{n m})$ \\
\hline R-G1 & $8.98 \mathrm{E}+02$ & 7 & $2.55 \mathrm{E}-10$ & 2.1 & 0.79 \\
R-G2 & $2.13 \mathrm{E}+03$ & 17 & $1.95 \mathrm{E}-10$ & 2.6 & 1.04 \\
R-G3 & $4.75 \mathrm{E}+03$ & 37 & $1.40 \mathrm{E}-10$ & 0.6 & 1.44 \\
RM-G1 & $1.01 \mathrm{E}+03$ & 9 & $2.34 \mathrm{E}-10$ & 0.6 & 0.86 \\
RM-G2 & $2.24 \mathrm{E}+03$ & 19 & $1.82 \mathrm{E}-10$ & 1.7 & 1.11 \\
RM-G3 & $4.87 \mathrm{E}+03$ & 39 & $1.33 \mathrm{E}-10$ & 1.5 & 1.52 \\
H-G1 & $8.54 \mathrm{E}+02$ & 7 & $2.48 \mathrm{E}-10$ & 1.3 & 0.81 \\
H-G2 & $1.97 \mathrm{E}+03$ & 17 & $1.79 \mathrm{E}-10$ & 2.5 & 1.13 \\
H-G3 & $4.16 \mathrm{E}+03$ & 37 & $1.29 \mathrm{E}-10$ & 2.3 & 1.56 \\
HM-G1 & $9.67 \mathrm{E}+02$ & 9 & $2.33 \mathrm{E}-10$ & 2.6 & 0.87 \\
HM-G2 & $2.08 \mathrm{E}+03$ & 19 & $1.65 \mathrm{E}-10$ & 1.2 & 1.22 \\
HM-G3 & $4.28 \mathrm{E}+03$ & 39 & $1.25 \mathrm{E}-10$ & 1.7 & 1.62 \\
\hline
\end{tabular}

